Māori business perceptions of the potential use of biotechnologies in pest wasp management

By

\title{
Symon Palmer
}

A thesis submitted to the Victoria University of Wellington

in fulfilment of the requirements for the degree of

Master of Arts in Māori Studies

Victoria University of Wellington

March 2019 


\section{Abstract}

The government has set a target of Aotearoa becoming predator-free by 2050 . Scientists see biotechnologies as a potential solution for pest management at large scale, with wasps identified as an opportune prototype for consideration as a trial. Wasps are identified to be costing $\$ 133$ million annually to the New Zealand economy. Primary industries are most affected, spaces that Māori occupy as part of the burgeoning Mãori economy. Given the complex relationship Māori have historically had with genetic modification and biotechnologies, and their involvement with industries said to benefit from wasp eradication, the views from Māori businesses are important. In this thesis, a kaupapa Māori, mixed-methodology study is conducted with people from eight businesses who intersect on these issues. Interviews helped gauge the 'pulse' of where Māori businesses stand on these issues. Five novel biotechnologies being actively researched for potential use, including gene drive and pheromone lures, are presented to participants. Which, if any, biotechnology might be acceptable for pest control? Views ranged from accepting to disapproving. A diverse economy framework is used to deepen understanding of participant priorities and implications for business values. Economic factors take a backseat and Māori values surface in non-market activity, transactions that deviate from capitalism, which are found to play an important role in decision-making on biotechnologies. A diverse economy framework thus sheds far more light on an issue than simple impact calculations. Communication of biotechnologies to lay audiences needs attention. Furthermore, impartial and credible evidence from multiple sources, not just scientists, is needed to best inform people on these issues. 


\section{Acknowledgements}

This thesis would not be possible without the support and guidance of my supervisor Dr. Ocean Mercier, he mihi nui ki a koe, te kotuku rerenga tahi. Thank you for your continued encouragement and support. He mihi nui ki a Alan King-Hunt hoki, my colleague and friend who has shared this journey with me. Thank you to the various academics that have helped me get to this point: Dr. Vini Olsen-Reeder, Dr. Annie Te One, Dr. Lorena Gibson, Dr. Jo Smith, Dr. Annie Potts, and Karen Saunders. I am also grateful for the patience and support of my partner, whaea, and whānau. I would also like to acknowledge the National Science Challenge, and Ngāi te Rangi iwi, for their financial support. And of course, all the whānau at Te Kawa a Māui, thank you for your tautoko and āwhina. Mauri Ora! 


\section{Contents}

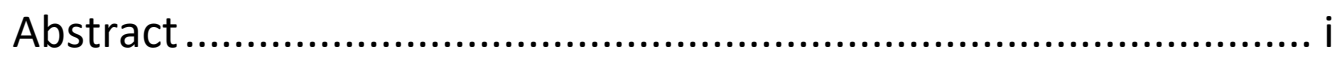

Acknowledgements .................................................................ii

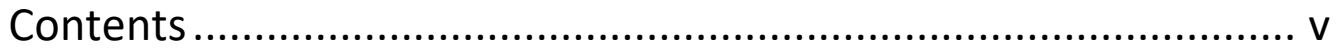

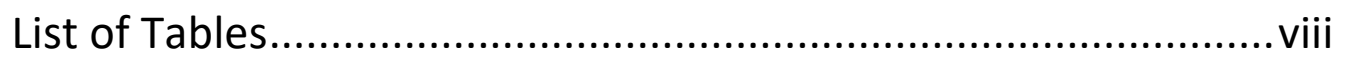

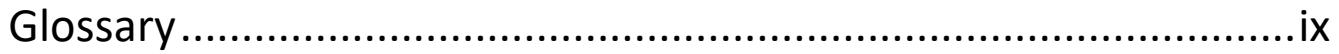

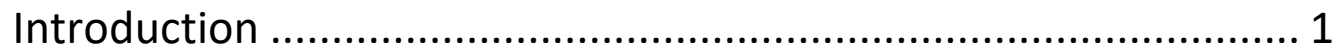

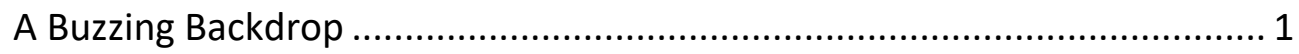

Take: The Purpose of this Thesis ............................................................ 4

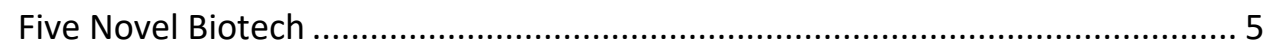

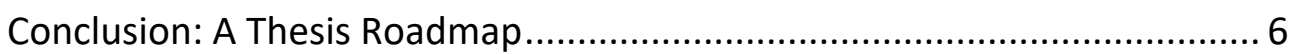

Chapter One: Literature Review................................................ 7

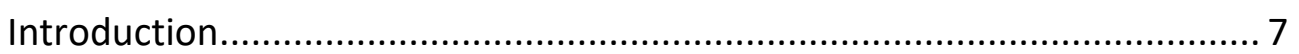

Context to a Māori Economy................................................................... 7

Economic Climate ....................................................................................... 9

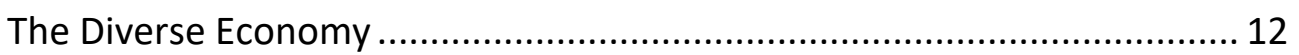

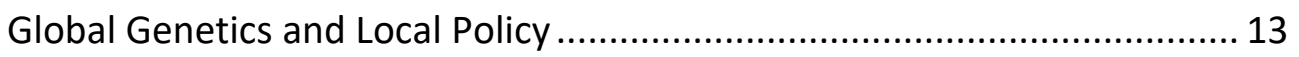

Under Threat: Māori Knowledge.......................................................... 17

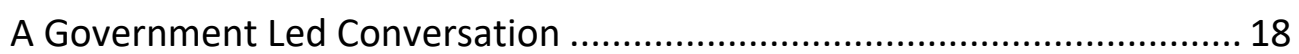

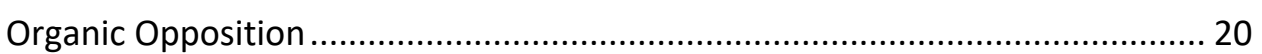

A Potential Benefit in Pest Management? .............................................. 22

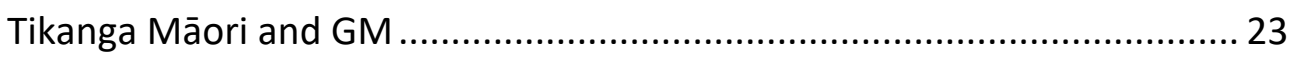

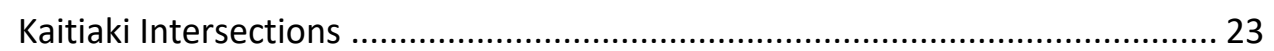

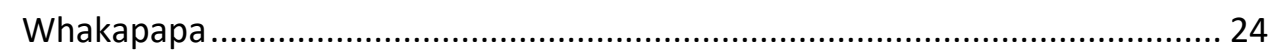

Māori Perceptions of Biotechnology ............................................................. 25

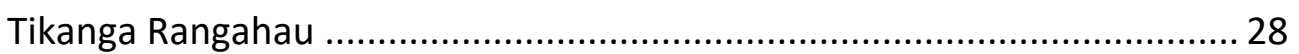

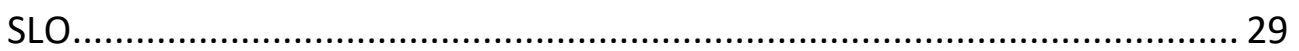

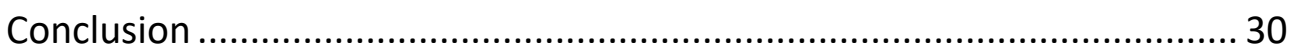

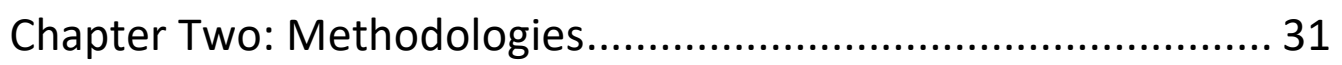

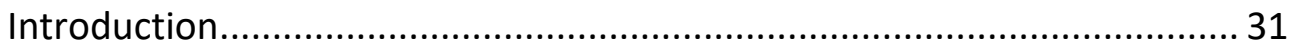

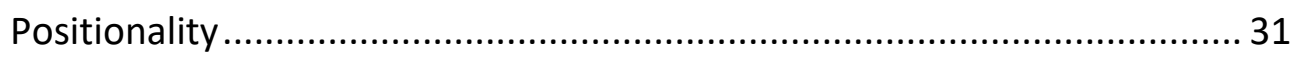

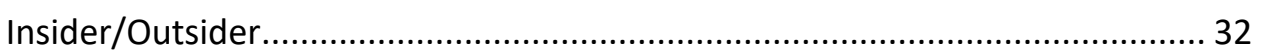

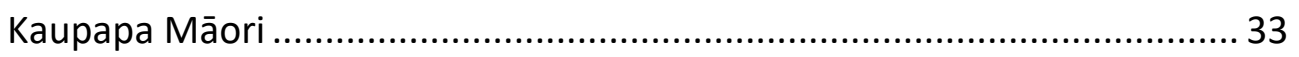

Constructing a Mixed-Method Approach .................................................. 35 


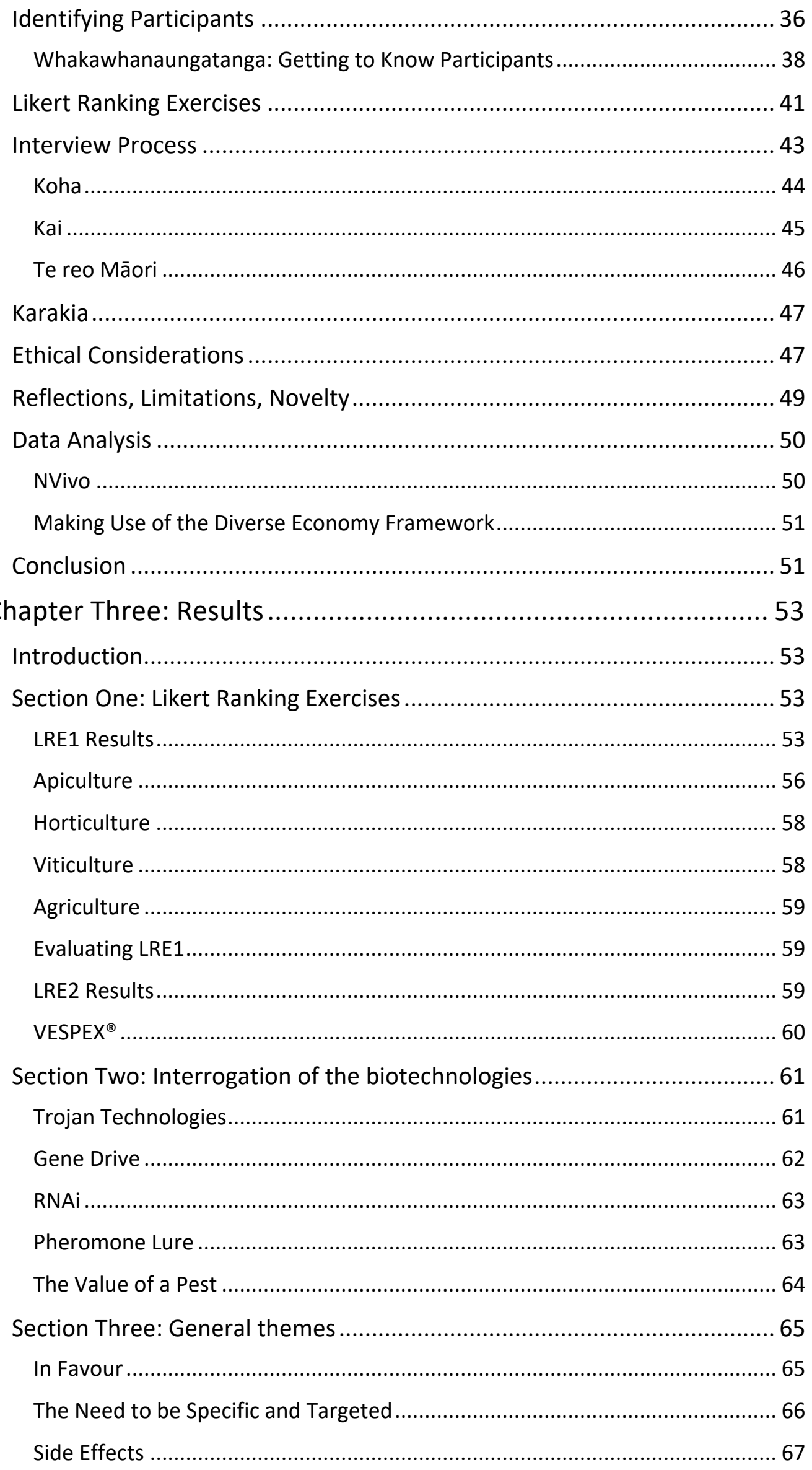




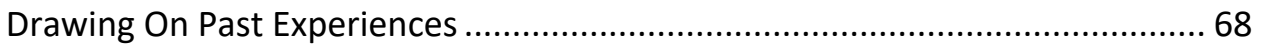

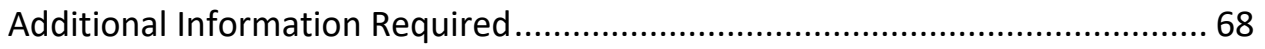

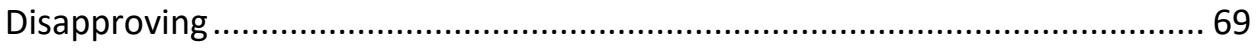

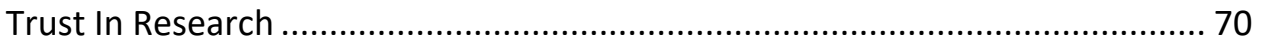

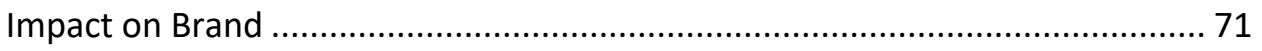

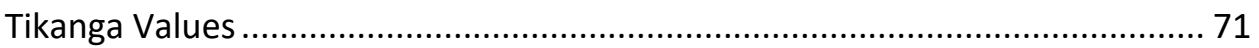

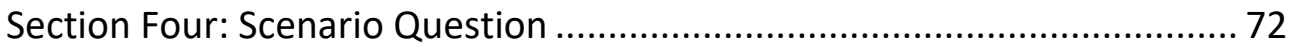

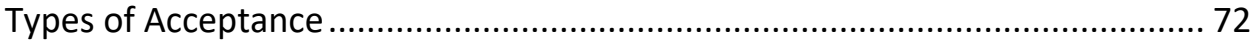

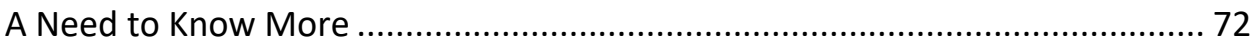

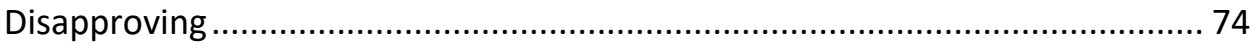

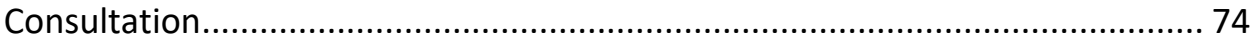

Section Five: A Diverse Economy Framework .......................................... 75

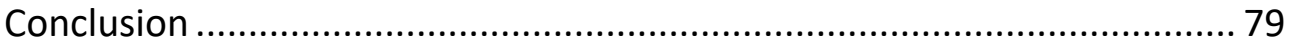

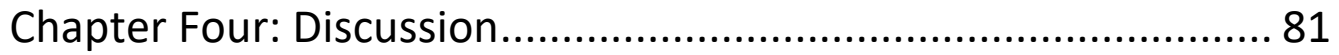

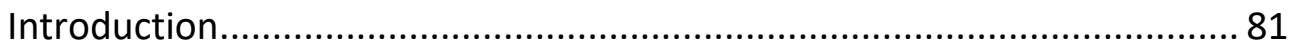

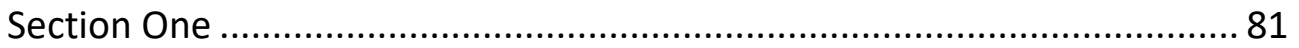

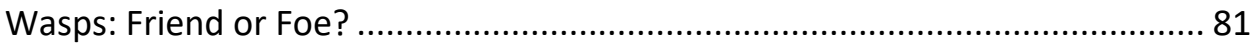

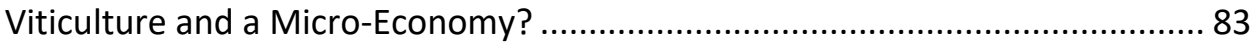

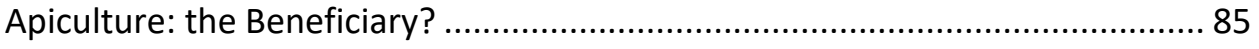

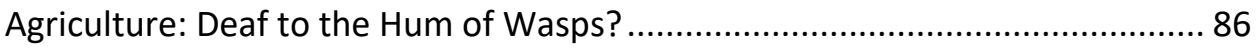

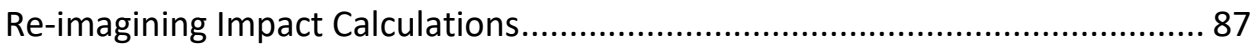

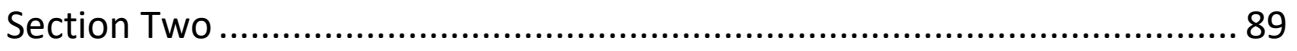

Diverse Economies: At the Forefront of Decision Making? ................................ 89

Defining Non-Market Activity and Tikanga....................................................... 90

Interpretation of Statements on Biotechnologies ............................................ 92

Market Influence in Pest Management ............................................................ 93

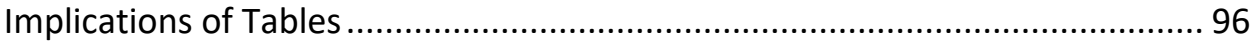

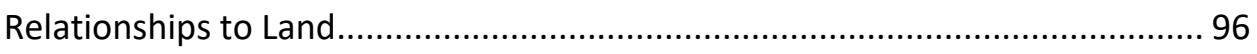

Diverse Economies: A Language for the Present .............................................. 98

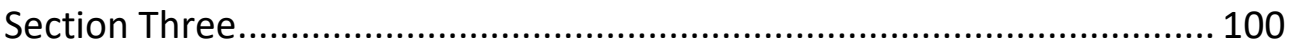

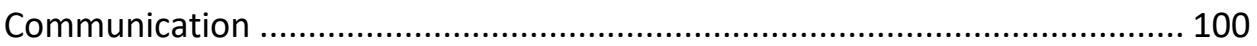

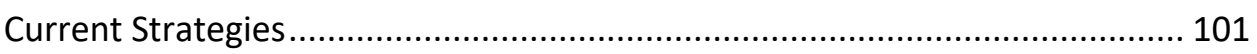

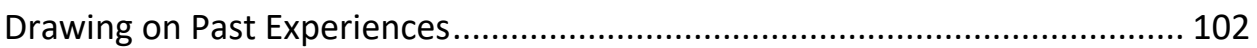

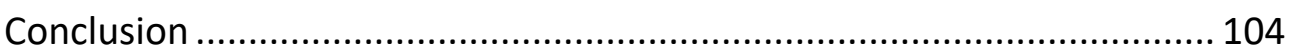

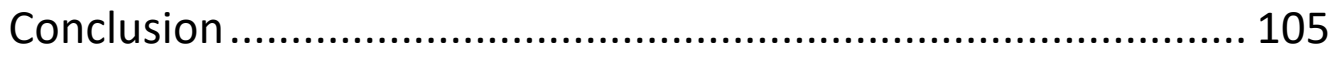




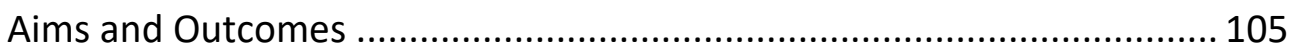

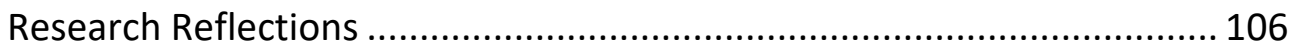

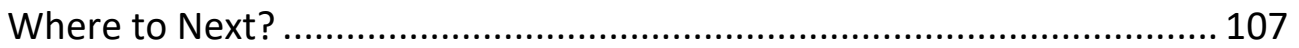

Bibliography ............................................................... 111

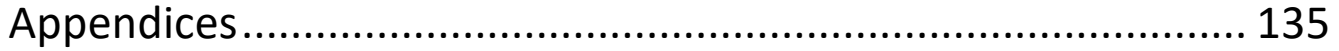

Appendix 1: Project Information Sheet ................................................... 135

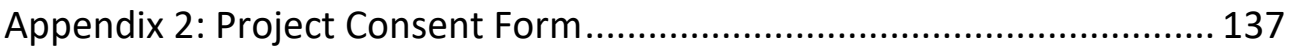

Appendix 3: Transcribing Confidentiality Agreement ............................. 138

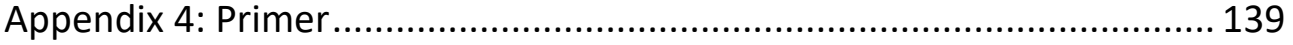

Appendix 5: LRE1 ….......................................................................... 140

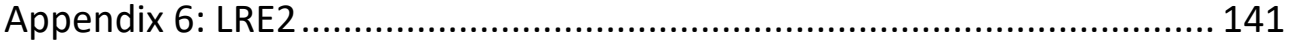

Appendix 7: LRE Raw Data.................................................................... 142

Appendix 8: Interview Questions ......................................................... 143

\section{List of Tables}

Table 1. Participation in a diverse economy framework .............................. 77

Table 2. Interpretation of statements on biotechnologies .......................... 91

Table 3. Market connotations, and interrogation of pest management

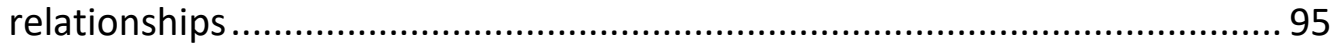




\begin{tabular}{|c|c|}
\hline ahi kā & fires of occupation \\
\hline awa & river \\
\hline hākari & feast \\
\hline hapū & sub-tribe \\
\hline hongi & pressing of noses to greet \\
\hline hui & meeting \\
\hline iwi & tribe \\
\hline kai & food \\
\hline kaitiaki & guardian, steward \\
\hline kaitiakitanga & guardianship, stewardship \\
\hline kapa haka & Māori performing group \\
\hline karakia & traditional incantations \\
\hline kaupapa & topic \\
\hline kawa & protocol \\
\hline koha & gift \\
\hline kōrero & talk \\
\hline kotahitanga & unity \\
\hline mana whenua & territorial rights \\
\hline mana & prestige/authority \\
\hline manaakitanga & hospitality \\
\hline manuhiri & guest(s) \\
\hline marae & tribal meeting grounds \\
\hline mātauranga & Māori knowledge \\
\hline mauri & life-force \\
\hline mihi & greeting/acknowledgement \\
\hline ngāhere & forest \\
\hline ngārara & insect \\
\hline Papatūānuku & Mother Earth \\
\hline pou & pillars \\
\hline pōwhiri & welcoming ceremony \\
\hline rangatiratanga & leadership \\
\hline
\end{tabular}




\begin{tabular}{ll} 
raupatu & confiscation \\
rohe & tribal area \\
rongoā & traditional medicine \\
take & purpose \\
tangihanga & funeral \\
taonga & treasures \\
tapu & sacred \\
te reo Māori & the Māori language \\
Te Waipounamu & South Island of New Zealand \\
tika & to be correct \\
tikanga & correct procedure, protocols \\
tohu & sign \\
tūpuna & ancestors \\
tūrangawaewae & standing place \\
utu & balance, compensation \\
wairua & spirit \\
whakaaro & thoughts, ideas \\
whakapapa & genealogy \\
whakawhanaungatanga & establishing relationships \\
whānau & family \\
whanaungatanga & relationship, connection \\
whenua & land \\
\hline
\end{tabular}

Note: English translations of Māori words are sourced from the literature they appear in, and Te Aka Māori Online Dictionary (Moorefield n.d.). 


\section{Introduction \\ A Buzzing Backdrop}

The 21st century has been dubbed the biotechnology century. Genetic modification is but one of many new technologies likely to become available. New Zealanders have always been quick to adopt and adapt new technologies, in whatever field they arise. Biotechnology will be no exception. (RCGM 2001:342)

At the top of Te Waipounamu (the South Island) in Aotearoa New Zealand's pristine beech forests, the drone of wasps drowns out the rich diverse native birdsong that once flourished. In fact, wasps literally outweigh birds - and every other insect in these forests - with a biomass of wasps is greater than all insects and birds combined (Thomas et al. 1990 cited in Lester et al. 2013) ${ }^{1}$. The German Vespula germanica and Common wasp Vespula vulgaris are behind these unimaginable occurrences. Said to have arrived as stowaways on cargo vessels (Lester 2018), wasps now have a stronghold among the beech forests and are purported to cost New Zealand's economy $\$ 133$ million annually (Maclntyre 2015).

Wasps compete with native species for food sources. Caterpillars, moths and spiders along with vertebrates are among the food sources for wasps, amounting to 1.4 - 8.1 kilograms per hectare, each season (Lester 2018:49-50). Wasps monopolise 90\% of honeydew, 5 months a year (Beggs 2001 cited in Maclntyre 2015:11), although, it has been noted that the data used to generate this statistic dates back to 1989 , a time that is widely regarded to be peak wasp population (Beggs et al. 2005 cited in MacIntyre 2015:11). Maclntyre (2015:11) estimates that wasp populations are currently less than at peak, and account for $50 \%$ of honeydew consumption. The argument built against these

\footnotetext{
${ }^{1}$ Referencing in this thesis adopt the Te Kawa a Māui variation of the Harvard referencing system, based on the Journal of Polynesian Society.
} 
international guests mounts further when considering what impacts they have to primary industries.

Maclntyre and Hellstrom (2015) argue that the German Vespula germanica and Common wasp Vespula vulgaris populations accrue a detrimental economic cost of $\$ 75$ million annually, totalling $\$ 772$ million from $2015-2050$ (based on net present value) in Aotearoa. These costs are spread across some industries at the forefront of biological invasions, primary industries, the most affected being apiculture $\$ 57.8$ million annually is estimated to be lost due to honeydew foregone to wasp populations (Maclntyre and Hellstrom 2015:12). Maclntyre and Hellstrom (2015:17) also predict a $0.5 \%$ increase of seed production in arable sectors, equating to $\$ 5.6 \mathrm{~m}$ (net present value) between $2015-2050$ because "[an] increase in pollination following the removal of wasps would translate into reduced pollination charges to growers". Additional benefits of a reduced wasp population could extend as far as agriculture where pollination is a billion dollar industry, and "...following the removal of wasps, nitrogen fertiliser applications could be reduced on all dairy farms and $75 \%$ of sheep and beef farms", consequently reducing the environmental impact of the dairy industry (Maclntyre and Hellstrom 2015:18). Thus, apiculture, horticulture and agriculture are ideal candidates for considering how businesses might feel about and pest wasp management.

A counterpoint sector to the businesses identified to benefit financially from the control of wasps is viticulture. Maclntyre and Hellstrom (2015:20) argue that there is no financial benefit to viticulture. Lester (2018:154) also notes that organic producers might benefit from wasps, although there are impracticalities in managing them. Intrigued by Maclntyre and Hellstrom's position on wasps, I stumbled across an article in which a wine maker stated they like wasps and encouraged their presence in the vineyard to act as an organic pest control method (New Zealand Wine n.d.). In contrast to the economic factors weighed against wasps, I decided to include viticulture in this thesis. 
Not long after MacIntyre and Hellstrom's study, in July 2016, the New Zealand government announced a $\$ 28$ million-dollar investment for efforts to eradicate pests on mainland New Zealand (New Zealand Government 2016). The scheme called Predator Free 2050 (PF2050) is eponymous to its core objective - to make New Zealand pest free by the year 2050. Three mammalian pests are targeted in the campaign: rats, stoats and possums. However, not all academics are convinced, one calling it "unachievable" (Victoria University of Wellington 2018).

Current pest management strategies remain based on poisons and manual trapping. Some new products have entered the market, like Good Nature traps $^{2}$, although these are still manual trapping devices. Manual extraction and disposal of wasp nests is also standard. A recent addition to pest management is the wasp targeting poison Vespex ${ }^{\circledR}$ (containing Fipronil), which has gained attention in mainstream media (Carson 2017); and is endorsed by the Department of Conversation (DOC) (DOC 2015). Mammalian predators - core to PF2050 goals - are also targeted by 1080 (Sodium fluoroacetate) a controversial broad spectrum aerial poison in use today (Green and Rohan 2012). Another poison in use is Broadifacoum, administered in bait stations.

PF2050 milestones include the hopes to "achieve a breakthrough science solution capable of eradicating at least one small mammal predator" by 2025 (Predator Free 2050 Ltd. 2018:29). Potential scientific solutions explore genetic advancements like "gene drive" (CRISPR Cas 9), a controversial technology that can alter genetic makeup. The technology “...use[s] gene repair mechanisms to insert, remove, replace or modify genes at predetermined sites in the genome" (Te Apārangi 2018:6). Scientists are urging caution in moving forward with these technologies (Oye et al. 2014; Esvelt and Gemmell 2017). Previous debates on genetic modification (GM) and genetic engineering (GE) are made relevant again, as this new stage in advancements of science persists. These issues have been argued by some Māori academics to be conflicting with

\footnotetext{
${ }^{2}$ An innovative trapping device targeting mammalian predators. The trap is synced with mobile software to monitor trapping and resets itself after each kill. See https://goodnature.co.nz/
} 
tikanga (cultural protocols) (detailed in the literature review). The development of new biotechnologies and the heightened profile of the unfavourable wasp leads scientists to believe they are the perfect prototype to trial such techniques with (Dearden et al. 2017).

Meanwhile, a Māori economy is emerging, said to be worth $\$ 50$ billion spread over several sectors (Chapman Tripp 2017). Contributing to this are Māori businesses that can operate in collectivised ways, through whānau trusts and iwi (tribe) assets (Te Kooti Whenua Māori 2010), extending beyond mainstream business models that are founded on exclusivity and individuality (Hutchings 2007:29). Alternative economic models are debated among academics to better understand business practices, in particular, the diverse economy framework developed by Gibson-Graham (2006) is seen to be valuable by Māori scholars (Amoamo et al. 2018b; Bargh 2011).

Māori businesses ${ }^{3}$ occupy the industries said to benefit economically from the potential use of biotechnologies. Biotechnologies and the related fields of genetics are a historically contentious subject for Māori. Such technologies pose risk to and taonga (cultural treasures) including natural resources of which Māori have tino rangatiratanga (self-determination) in the Māori text of the Treaty of Waitangi (Te Tiriti o Waitangi 1840). Although not upheld by the Crown, 'principles of the Treaty' remain, in which Māori are valued partners to the Crown. Māori are also valued partners in research, and are recognised for their own knowledge systems that might contribute to innovation and "synergies" (Ministry of Business, Innovation and Employment 2007). These compounding factors mean the views of Māori businesses are required on the topic of biotechnologies in pest management.

\section{Take: The Purpose of this Thesis}

Illustrated by Maclntyre and Hellstrom (2015), wasps have a detrimental impact to Aotearoa's economy and bio-diversity. Biotechnologies have are held

\footnotetext{
${ }^{3}$ In this thesis, a Māori business is defined as a business that is owned and operated by someone who identifies as Māori.
} 
contentiously by some academics, and have resurfaced as an option by scientists to control pests. These issues converge on PF2050, where further research is needed. Simultaneously, Māori occupy sectors said to benefit from the control of pest wasps. Therefore, the take (purpose) of this thesis is:

1. To gauge, how do Māori in Māori-businesses feel about novel biotechnologies in pest management, with particular regard to wasps?

2. Under what conditions might these biotechnologies be deemed acceptable?

3. Are these businesses involved with diverse economy practices, and, if so, how does this play a role in decision making?

This thesis is unique in that it is a business-specific study of Māori perceptions of biotechnologies in pest wasp management. This study sheds light on the complexities of industries said to benefit from the eradication of wasps, and, raises questions on what steps are required moving forward. Additionally, it appears at the same time as two other studies in the field of Māori perceptions of biotechnology emerge, led by Dr. Ocean Mercier and Alan King Hunt respectively.

A mixed-method approach has been taken in this thesis. Kaupapa Māori methodology anchors the formulation and execution of the in-depth qualitative interviews in this study. Two Likert ranking exercises are utilised to gauge immediate impressions from participants and warm participants to biotechnology discussion. These components provide a culturally safe method for research with Māori, and enable multiple types of data to be generated (further explained in the Methodology chapter).

\section{Five Novel Biotech}

In this thesis I present five novel biotechnologies to Māori businesses located in industries that I identified to potentially benefit from the eradication of wasps. Here I will briefly summarise what consists of each biotechnology. In this study, the following techniques are identified as biotechnologies:

- pheromone lure: an artificial pheromone that manipulates pest behaviour; 
- gene drive: genetic modification of a gene that will be passed on to future generations;

- $\quad$ RNA interference (RNAi): gene silencing using double stranded RNA could be used to stop fertility;

- Trojan female: a lab reared female wasp that produces sterile males

- Trojan mite: a pathogen carrying mite that infiltrates hives, killing wasps (Mercier et al. 2019).

As signalled in the beginning of this chapter, the economic practices of Māori are at times divergent of capitalism, provoking the consideration of alternative routes to business. Accordingly, this thesis makes space for this by including a 'diverse economy framework'. Developed by Gibson-Graham (2006), it seeks to disrupt capitalism by revealing non-market activities and alternative modes of transactions to help re-imagine the economy. The framework is later utilised in both the results and discussion chapters to impart new lens on the data generated. A detailed explanation follows in the literature review.

\section{Conclusion: A Thesis Roadmap}

The structure of this thesis follows with a literature review. This will show how Māori operate in a contentious economic climate; previous research on Māori views on biotechnology and related fields will also be discussed. In the Methodology chapter, an exploration of how a mixed-method kaupapa Māori methodology is constructed will be conveyed, recounting the interview process and reflecting on the actual outcomes and limitations. Next, the results of this study will be presented, leading to the discussion chapter which will highlight implications of the findings and considerations for the future. Finally, thoughts will be gathered and draw to a close in the conclusion chapter. 


\section{Chapter One: Literature Review \\ Introduction}

Two main areas of literature are explored in this chapter: Māori economy, and Māori perceptions of biotechnology. The emerging discourse on a Māori economy discourse is located in a 'post-settlement' era, supplemented by a brief overview of the current economic climate. The Māori economy literature will provide key context to how Māori businesses operate in a capitalist framework, illuminating characteristics that might be differ from mainstream business activity. Diverse economies, a key theoretical framework for analysis in this thesis, is described. Transitioning into the realm of biotechnology, I focus on topics that converge on Māori ways of knowing such as ethics, bioprospecting, biotechnology, genetic modification, and bio-medical research. These issues are then located within local and international contexts.

\section{Context to a Māori Economy}

Māori have long participated in Western contexts of economy through trade with early settlers, contributing significantly to early wheat trade (Petrie 2006). Pre-contact trade occurred between other Pacific islands and inter-tribally, for example, inland tribes traded birds or kūmara for the kaimoana (seafood) of coastal tribes (Petrie 2006). Mānuka Hēnare argues that traditionally, the Māori economy was an 'economy of mana', where production was based on needs and tikanga, while considering the needs of future generations and tūpuna (ancestors), "it prioritises holistic wellbeing and creating value over 'profit maximisation'” (2014:66).

The Māori economy has experienced strong growth in recent years. Reported to be worth $\$ 36.9$ billion in 2010 (Nana et al. 2011), and \$42.6 billion in 2013 (Nana et al. 2015); it has most recently been estimated to be $\$ 50$ billion (Chapman Tripp 2017). The government has recognised the potential of the Māori economy, releasing an 'investor's guide' to commercial endeavours with Māori (Ministry of Business, Innovation and Employment 2017a). Targeting offshore investors, the document highlights the attractive nature of investing in the Māori economy, which has $5 \%$ growth, significant in comparison to $2.7 \%$ 
growth in the New Zealand economy and 3\% for the world economy (2017a:7). Crown Research Institute, Scion, focused on forestry innovation, has targeted Māori outcomes that aim to generate $\$ 2.7$ billion more than "business as usual" in economic activity by 2040 (Scion 2017).

Durie (2011:48) argues that Māori enterprise has been enhanced by the Treaty settlements process. This process seeks to settle historical grievances with the Crown (Wheen et al. 2012), such as raupatu (land confiscations). Claims of Treaty breaches are made to the Waitangi Tribunal, involve lengthy negotiation with the Crown, and if agreed upon, settlement may be received in the form of an apology, cultural redress, assets, property, and cash (see Wheen et al. 2012). Although some Māori academics argue that unjust processes undermine Treaty settlements (Mutu 2018).

The growth of the Māori economy has not translated to equality among Māori. A recent report from Te Tokona Te Taki, Māori Futures Collective, estimates a \$2.6 billion income inequality for Māori, generating $\$ 700$ million in tax revenue (Shuzle \& Green 2017). Chief economist Dr. Ganesh Nana highlights the financial inequality: "...this represent people's opportunities, lives and wellbeing being eroded" (Shuzle \& Green 2017:5). Elsewhere, it is predicted that by 2035, Māori will represent almost $20 \%$ of Aotearoa New Zealand's population, with a median age of 24; the Pākehā median age 44 years (Durie 2011:223). This points towards a need for the government to enhance opportunities for Māori equality in Aotearoa's economy, potentially benefiting the government in tax revenue.

The growth of the Māori economy and the iwi asset base has generated questions on how Māori conduct business and what role tikanga will play. Hēnare (2014) offers an application of tikanga values suitable for the Māori economy and the workplace:

- Tapu as a theory of being

- Mana as a theory of Power, authority and ends

- Mauri as a theory of life and its causation

- Hau as an integrative theory of life force and economics that involves obligatory reciprocity and social relationships 
- Kotahitanga as a theory of human solidarity. (Hēnare 2014:69) Dell et al. (2018) argue that enhancing mana is key to decision making for Māori and should be explored within business. Spiller et al. (2011) advocate for businesses to consider Māori values like kaitiakitanga, to make wise actions and produce well-being outcomes, drawing on Māori Mardsen (2003) who emphasises the importance of kaitiakitanga and spiritual connections. Māori entrepreneurship is argued to involve ancestors and future descendants, representing "...shareholders in their outcomes" that "...prioritize holistic wellbeing and value creation over profit maximization" (Hēnare et al. 2017:210).

The literature shows that Māori businesses draw on principles of tikanga Māori (cultural protocols). Also evident in several Māori organisations is an intersection of mainstream commerce and Māori values (Carter et al. 2011). At this interface, commercial imperatives and cultural safety are negotiated in different ways, presenting alternative routes to business. The economic climate influences this relationship. Thus, the following section provides mainstream economic context.

\section{Economic Climate}

In this section a brief definition of the key concepts academics have signalled in the Māori economy discourse will be identified and explored. Resistance to global market forces by Māori will be highlighted, showing a need for alternative economic models. What this means for Māori in this study will then be summarised.

The economy of today is defined by neoliberalism, globalisation, and commodification. Neoliberalism seeks to entrench free trade, promotes the privatisation of services traditionally run by the State (e.g. health, education and prisons), and encourages privatisation of assets like property (Bargh 2007; Harvey 2005). "Decentralising the state and shifting service delivery to the private sector is a key neoliberal strategy" (Bargh 2007:37). Other characteristics include deregulation of policy, higher productivity, intellectual property rights and increased competition (Harvey 2005). Neoliberalism is linked to globalisation as corresponding practices (Bargh 2007:1). 
Māori have responded to neoliberalism and globalisation in different ways. Māori lawyer and activist Annette Skyes (2007:116) suggests that Māori culture is under threat from neoliberalism and globalisation, suggesting basic modes of resistance like not participating in globalised products like KFC and McDonald's. Globalisation is linked to colonisation by several academics, described as a relative to colonialism (C. Smith 2007). Jackson (2007:176) also compares colonisation to globalisation - a subordination to a Western way of doing business. Resources that were once respected by Indigenous peoples became commodified (Jackson 2007:177). Cheryl Smith (2007) describes colonisation as the period of "...dreams of advancement"; while globalisation is the "...entrepreneurial spirit that encapsulates the dream of roaming the world and discovering untapped resources" (2007:69-70).

The impact of neoliberalism on Māori communities is made tangible in how iwi are taking on responsibilities like social housing and healthcare that were previously matters of the State. One example is Ngāti Whatua, who recently invested in private health care insurance for all tribal members (Ngāti Whātua Ōrākei 2018). Strategically, neoliberal advances to play to Māori aspirations of tino rangatiratanga (self-determination) by giving control of a previously state funded entity to Māori who will then bare market consequences and targets required to sustain the project (Jackson 2016:46-47). Elsewhere, Ngāi Tahu have built business portfolios in tourism, farming, and commercial property development (Te Rūnanga o Ngāi Tahu 2017). In economic terms, Ngāi Tahu growth has been exemplary. Even so, Poata-Smith (cited in Hokowhitu 2010:213) has critiqued the notion that Māori interests in the contemporary capitalist economy are unified. Thus, a spectrum of investment can be seen in the Māori economy.

Poata-Smith (2004:60-61) also argues that the Treaty Settlement process and the neo-liberal infrastructure of New Zealand (introduced by the fourth Labour government) has forced iwi to re-structure, now resembling a corporation where CEO's are in control of assets and direction. Similarly, Bargh (2007) demonstrates that Treaty settlements force participation in neoliberal policies, 
while simultaneously eroding alternative forms of governance. Bargh (2007:36) problematizes the complacency of Māori leaders, suggesting a belief by some that neoliberal avenues will deliver self-determination.

More recently, Bargh (2014) has said that Māori face a new challenge in a postsettlement society, the 'triple crisis', as described by Shiva (2008 cited in Bargh 2014): climate change, peak oil and food insecurity. Durie (2011:64) acknowledges these crises and the risk posed to low lying Pacific Island communities. The capitalist priority, to generate revenue, outweighs environmental considerations (McDonough and Braungart 2002 cited in Bargh 2014). A 'green economy' is often seen to be a route to navigate the triple crisis by investment in sustainable business practices and renewable energy sources, however, these must work with Māori values (Bargh 2014). Bargh (2014) highlights potential for further research in Gunter Pauli's (2016) "blue economy" theory which illuminates reduction in environmental impacts and creating positive by-products.

Meanwhile, Tanira Kingi (2013 cited in Hutchings 2017:8-9) is critical of how the government calculates productivity of Māori land, arguing that Ministry of Primary Industries found only $20 \%$ of Māori land to be productive, failing to account for intergenerational aspects, conservation through kaitiakitanga, and tikanga Māori. Amoamo et al. (2018a) also critique the traditional capitalist economy for its failure to consider Māori ways of knowing. The Treasury has recently signalled interest in new calculation methods with their Living Standards Framework which considers four 'capitals': human, social, nature, and financial (New Zealand Government 2018). Elsewhere, Carter et al. (2011:25) have asserted that "[In] the future discussion we need to move beyond GDP...".

The preceding arguments highlight growing concern for the practices and byproducts of capitalism. Māori are critical of neoliberal policy and the impacts of globalisation which show parallels to colonisation. Māori concerns for tino rangatiratanga and kaitiakitanga are tikanga unaccounted for in mainstream concepts of business, creating a need for alternatives to capitalism. 


\section{The Diverse Economy}

Gibson-Graham (2006) have developed a language for a diverse economy to better observe alternative market practices. Central to their theory is "capitalocentrisim", the hegemonic discourse that fails to recognise alternative forms of economic activity (ibid.). A diverse economy framework can be used to examine: transactions (e.g. goods and services, exchanges), labour (e.g. paid and unpaid work), and enterprise (e.g. organisation structure); each reveal forms of capitalism, alternative capitalism, and non-capitalist notions (GibsonGraham 2006; Gibson-Graham and Roelvink 2011).

A diverse economy lens on transactions in business sheds light on complex practices. Specifically, non-monetary activities of house-work and volunteerism resist capitalocentrism and are referred to as non-market transactions (Gibson-Graham 2006). Non-market transactions extend to hunting, fishing, gathering seasonal foods (2006:76); eliciting comparison to Māori tikanga e.g. mahinga kai (traditional food sources). Non-market transactions include Filipino cultural practise of Dajong, "neighbourhood mortuary assistance including money, food and services" (2006:175). A practice that resonates with tangihanga (funeral), where whānau, iwi, and guests make contributions through gifts of food, resources or money to facilitate the grieving process (Mead 2003:102-103). Tangihanga, alongside kapa haka (Māori performing group) and marae (meeting places) are identified by Dell et al. (2018:60) as 'sub-economies' that should be examined closer in order to reimagine economic institutions. Amoamo et al. (2018a; 2018b) proposes that a diverse economy framework may provide a more empowering language to describe Māori businesses; a way to express business practices outside of economic measurements. Furthermore, "many of the key points in diverse economies have parallels in Kaupapa Māori research and decolonisation discourse (2018b:74). Thus, examples from Gibson-Graham look transferable to many Māori tikanga, and have been explored Māori academics.

Bargh (2011) utilised the diverse economies framework to study Tuaropaki Power Station, a Māori owned geothermal business, revealing new ways of 
understanding the layers of transactions that take place in Māori enterprise. Bargh (2011:64) finds links to kaitiakitanga and non-market activity; koha (gifting) is interpreted as alternative market activity. Bargh (2012:277) also links Gibson-Graham and Roelvink's (2010) later theory of "ethical coordinates" to Māori concepts of mana (prestige), utu (balance), kaitiakitanga and whakapapa (genealogy). Although ethical coordinates may provide another lens to economic activity, its application to Māori is less prevalent in the literature. Nonetheless, Māori academics reinforce previously identified calls to include Māori values in business (Spiller et al. 2011; Hēnare 2014). Bargh and Jacob (2009:159) have also remained critical of Gibson-Graham (2006:xii) for their implied neutrality of land, which could be interpreted as an erasure of Indigenous people and their histories. However, the theory of a diverse economy stands to be adopted for discourse by Māori academics (Amoamo et al. 2018a; 2018b; Bargh 2009; 2011).

The notion of a diverse economy framework, combined with the burgeoning Māori economy and a limited representation of Māori worldview in current economic practices has stimulated discussion on its potential use. Implied by the literature is a new tool to unpack Māori business practices that are yet to be cited by mainstream calculations. The close relationship of non-market descriptors and tikanga poses further exploration. Considering these factors, testing the diverse economy framework within the context of the potential use of biotechnologies in pest management might reveal concerns of Māori businesses that are yet to be identified by mainstream investigations, motivating its integration in this thesis.

\section{Global Genetics and Local Policy}

Internationally, interest in the study of genetics has persisted resulting in innovative projects that raise concerns for Indigenous peoples. Here, I transition to some older debates that set the scene for a discussion on biotechnologies. Relevant policy in Aotearoa will then be analysed.

A tipping point historically was the Human Genome Diversity Project (HGDP), a multinational funded research expedition that sought to map human genetic 
material and sequence 3 billion DNA letters, providing its' findings as an open source body of data, free for scientists to mine (HGP 2003). Such a project summons issues of Indigenous rights and market motives.

Similarly, the Genographic project, started in 2005 , aimed to get 100,000 Indigenous DNA samples to assist in their goals of tracing human migration over time (Armelagos 2012). Participants purchased a \$99.99 USD DNA home testing kit via their partner website, National Geographic, to receive an analysis of their genetic makeup (Ibid.). Today other providers of this service, unconnected to large populations surveys (so they say) are available, the most popular being Ancestry.com. Elsewhere, the FBI recently gained access to a home-kit DNA provider's database, posing concern as to who has access to DNA data (Brown 2019). Such concerns touch on issues of data sovereignty (see Kukutai and Taylor 2016).

Academics were critical of the HGDP from its conception. Sandra Awang calls it “...colonial, patriarchal, capitalist, racist, scientific/materialistic surge to acquire the living cells and biodiversity..." of marginalized peoples (2000:121). Hindmarsh and Lawrence (2004:24) said "...it failed to live up to its high expectations as the Holy Grail of biotechnology to explain how life is ordered by genes". Western science research is also critiqued by Medin and Bang (2014) who says that values, as well as gender, class and culture, can impact results and how research is framed. The criticism of HGDP is akin to the concerns of biopiracy. The Indigenous Council on Biocolonisalism dismissed both the HGDP and the Genographic project citing ethical and cultural concerns, which were also taken to the United Nations Permanent Forum on Indigenous Issues (Harry and Kaneche 2006).

Recently, concerns regarding eugenics have resurfaced in a Monash University publication, in which Anamoly (2018) states a case for revitalising the research domain. Criticism of the article, by the Australian Critical Race and Whiteness Studies Association cite the authors' racist motivations and attempts to negotiate population control among the less able and people of colour (Lentin 2018). 
Hallan (2004) traces the global interest in biomedical health research back to the culmination of neo-liberal policies being phased in by governments around the world, globalisation, the increased costs of modern medicine, and the potential to develop this by way of public-private partnerships. The HGDP was seen as a way to decrease costs in biomedical research by creating a base knowledge of genetics (Hallan 2004:145). Pharmaceutical companies were quick to invest in the growing sector of biomedical heath research, and now have the power to steer research towards "diseases of affluence" (Ibid.). Thus implying that research would be marketable and have commercial outcomes for pharmaceutical companies.

Relevant to these global issues, and the subject of biotechnologies is the consideration of policy here in Aotearoa. Here, a snapshot of the key policy and governing agencies will be identified, followed by critique.

Māori interests and Crown obligations to Māori have been signposted in policy such as the Hazardous Substances and New Organism Act 1996 (HSNO).

- $\quad$ S2 (section two) states consultation is required when venturing into GM or GMO development;

- S8 cites the Treaty of Waitangi principles (Roberts et al. 2004; HSNO Act 1996).

- S5(b) states: "the maintenance and enhancement of the capacity of people and communities to provide for their own economic, social, and cultural wellbeing and for the reasonably foreseeable needs of future generations" (HSNO Act 1996).

- S6(d) sates: "the relationship of Maori and their culture and traditions with their ancestral lands, water, sites, waahi tapu, valued flora and fauna, and other taonga" (HSNO Act 1996).

When HSNO was passed in 1996 the Environmental Risk Management Authority (ERMA) was simultaneously created, now called the Environmental Protection Authority (EPA). At its conception, ERMA employed a single Māori policy advisor who was responsible for "...all "Māori” matters..." [original emphasis] (Satterfield and Roberts 2008:208). Applications for GM and or new organisms are taken on a case by case basis, evaluated by the EPA (previously known as ERMA, subject to public notification, and in some cases a hearing (MFE 2004). The HSNO Act is modelled on the Resource Management Act 1991 
(RMA) (Satterfield et al. 2005); failures and injustices caused by the RMA have long been criticised by academics (see Mutu 2002; 2010; Stephenson 2002).

Ngā Kaihautu Tikanga Taiao (NKTT) is the Māori advisory board for applications to the EPA. They acknowledge Māori concerns of GM as: the mixing of whakapapa, health concerns associated with human consumption of transgenic genes, and economic risk in exportation of products that might be affected by GMO (Cram 2005:59). Satterfield and Roberts (2008:208) have critiqued NKTT for being employees, and the 'vetted' nature of the board, meaning that "...their representation of Māori views was constrained". It is also emphasised that the board were in an advisory position, lacking teeth (Satterfield and Roberts 2008; Waitangi Tribunal 2011:77). Baker (2012:96) found that Māori who had participated in NKTT processes, felt uninformed on these GE issues due to poor information and communication.

The Royal Commission on Genetic Modification made recommendations to reword HSNO Treaty obligations from "take in to account", to something less “tokenistic" (RCGM 2001:308 cited in Solomon 2007:80). Changing the Treaty section phrasing to "shall give effect to the Treaty of Waitangi" was suggested, thus increasing the responsibility to adhere to the Treaty (Satterfield and Roberts 2008:210); although the RCGM found HSNO policy was adequate in the management of GM (RCGM 2001:331).

Currently, in Aotearoa any GM food must be labelled if any characteristic has been changed, with the exception of "GM foods that do not contain any novel DNA or novel protein, and do not have an altered characteristic" (ANZFA 2016), creating ambiguity in GM food. Recently, related policy, the RMA was amended to remove any local or regional council responsibility to "...regulate hazardous substances in RMA plans, or policy statements" (MfE 2017:5). Despite that, during a biotechnology discussion workshop I attended at the Royal Society Te Apārangi, HSNO was described by relevant industries and law experts as by no 
means designed to deal with the current state of genetic engineering ${ }^{4}$, suggesting inadequate policy infrastructure that needs to be addressed by the government.

Global advancements in genetics prove to be complex and problematic in policy making. The literature implies stagnant and under-equipped policy regulates these contemporary technologies. In the following section, the threat this poses to Māori knowledge will be explored.

\section{Under Threat: Māori Knowledge}

"Biopiracy is akin to colonisation..." (Hutchings 2015:36).

Cheryl Smith (2006) argues that Māori have voiced their concerns over GM since its conception. GM poses a breach to tikanga and Indigenous knowledge, risking misuse and capitalisation by transnational corporations (Hutchings 2004:181). It has parallels to colonising activities in the collection and exploitation of biological resources (C. Smith 2006; Hutchings 2015). Hutchings (2004a:181) argues that there are no clear benefits to Māori, and a lack of control in the use of Māori genetic material risking further inequities. Central to these concerns are issues of biopiracy and bioprospecting which are exploitative in their nature (Seini 2004:192), preying on Indigenous communities. An example of bio-prospecting is given by Ratuva (2007:97) where a Fijian community was denied recognition in a deal which saw a Scottish company given rights to harvest dried raw materials via a contract with the local University. In the Royal Commission on Genetic Modification (which will be discussed in more depth later) bioprospecting is described as:

the exploration of biological material in order to provide chemical components, genes and their products for potential use and development in pharmaceutical, agrochemical, biotechnology, cosmetic and other applications. (DOC 2000 cited in RCGM 2001:166)

Divide between government and Indigenous scholarship is further exemplified in the ways Māori challenge biopiracy, who, alongside other Indigenous

\footnotetext{
4 'Gene editing in Aotearoa' a workshop series, took place in Wellington on the 11th of April 2018 at Te Apārangi, The Royal Society of New Zealand.
} 
cultures, have their own knowledge systems, now generally known as mātauranga - translated as Māori knowledge. Mātauranga is an allencompassing Indigenous way of knowing with cosmological links (Hutchings 2002). Mātauranga also extends to rongoā (traditional medicine), which Mānuka honey is recognised for (Waitangi Tribunal 2011). Thus, concerns realised here also impact Māori businesses, in this case, apiculture.

The Waitangi Tribunal claim Ko Aotearoa Tēnei (Wai 262) discusses the intellectual and cultural property of Māori, with particular reference to flora and fauna (Solomon 2007), relevant to discussion on GE. GE was already on the radar of claimants prior to the 1991 submission of Wai 262, regarding the negative impact to whakapapa of humans and all living things (Solomon 2007:79). Barker (2010:119) found that GE posed an interference to how mātauranga would be maintained going forward, reiterating the concerns of WAI 262. Control and protection of mātauranga is a priority to Māori, as the commercialisation of Indigenous knowledge by local and international corporations is alarming (Baker 2010:122). Universities and places of research perpetuate Western ideologies that have historically silenced Indigenous knowledge (L. T. Smith 2012:78). Such historical links are likely to contribute to Māori caution towards genetic research.

\section{A Government Led Conversation}

The New Zealand Royal Commission on Genetic Modification (RCGM) was established in the year 2000 with the intent of evaluating New Zealand's stance on genetic modification and what approach would be used to inform policy and regulation going forward. It received thousands of submissions from industries such as, food, agriculture and medicine, to political parties like the Green Party of New Zealand, and organic organisations and advocates. The Royal Commission deems any alteration, transfer, modification, or construction of genes to be genetic modification and synonymous with genetic engineering (RCGM 2001:5). 
Horticultural concerns were raised in an RCGM submission by the kiwifruit industry. They emphasised the importance of a GM free product in the European market, stating that it could potentially jeopardised if modified crops cross-pollinated nearby non-GM crops (RCGM 2001:337). In response, the Commission recommended "exclusion zones" for GM crops in established industries (Ibid.). The RCGM asserted that GM would be essential to Aotearoa's economic potential in the future, influencing the health sector, forestry, and crop development (RCGM 2001:332-334).

The RCGM recommended the establishment of a Bioethics committee (RCGM 2001). The Bioethics Council of New Zealand was disbanded in 2009 by the National Government (Radio New Zealand 2009). However, identified earlier, the NKTT appears to have a similar responsibility. The government responded to the RCGM by amending the HSNO Act in 2002. The new amendment placed a two year restriction on GMO applications to allow time to implement the proposed considerations that the RCGM produced (MFE 2002:4).

...bioethics has become a new and contradictory label that seeks to rationalise genetic modification purely on the basis of 'reality' and a supposedly superior intellectual framework. (Jackson 2007:180)

The RCGM came under scrutiny by academics. Hutchings and Reynolds (2004:9) critique the RCGM, in which a number of Māori submissions opposed any form of genetic modification as it would undermine whakapapa, with the exception of some "paid Māori consultants" who were for it. However, the commission "seemed to politely acknowledge these concerns and then dismiss them" (2004:9). Hutchings and Reynolds (2004:16) were also critical of the single Māori commissioner on the RCGM, Dr. Jacquiline Allen (Ngāi Tahu). They analyse her contribution to be one that is not of mana wahine origin, instead it is argued to reproduce hegemonic narratives of patriarchal colonialism. Elsewhere, Hutchings (2002; 2004a; 2004b) has published on the marginalisation of mana wahine perspectives (sometimes referred to as Māori feminism) in the GM debate, caused by the patriarchal masculinities that make up Western science, who set the agenda for discussion. This harsh assessment of Allen provides a vital outsider analysis of the RCGM. 
Critique of the RCGM suggests that the Commission disempowered the 10,000 submissions opposed to $\mathrm{GM}$, rather, selectively prioritising a survey that showed potential acceptance of GM: leading to the colloquial name, the "Royal Omission" (Campbell 2004:43). Campbell (2004:44-45) says that the Commission process privileged parties that had invested interests in GM; arguing that during the RCGM, a binary was produced between organic agriculture and GM by media coverage. Media “...deliberately seek bipolar narratives to sensationalise everyday politics" (Etzioni 2010 cited in Coombes 2013:82). Chomsky (2004) critiques media to be conflated with corporations, agenda-setting, political aims, and theories that allude to issues of transparency and trust.

The organic sector plays an interesting role in the discussion of GM and food. Campbell (2004:46-48) argued that the organic sector performed well in the RCGM due to its tangible infrastructure (e.g., Green Party of New Zealand, and Greenpeace). In next section, an examination of organic opposition to genetic advancements will be presented to provide background on contemporary views towards these technologies.

\section{Organic Opposition}

The resistance to GE in Aotearoa, which has come from diverse Māori communities, is aimed at this global industry. New products developed through GE are connected with acts of biopiracy and bioprospecting that place value on the commercial potential of nature, rather than on her regenerating, life-giving capacities. GE is at the other end of the spectrum to te mahi māra hua parakore. (Hutchings 2015:37)

Hutchings et al. (2012) represent a collective of Māori organic food growers, Hua Parakore, who are strongly opposed to any form of GM, nanotechnology, or pesticides. Hua Parakore is also a response to the 'triple crises' of climate change, peak oil, and food insecurity (Shiva 2008 cited in Hutchings et al. 2012), emphasising the reclamation of food sovereignty. It is a response to the commodification of food by multinational corporations that evoke neo-colonial food practices (Hutchings et al. 2012). Hua Parakore meets the requirements of the New Zealand Standard for Organic Production NZSA 8410.2003 with the addition of self-prescribed "Māori organic" standards that draw on tikanga, 
among them are: whakapapa, mana, and wairua (spirituality) (ibid.). Hua Parakore resists GM, and is a unique Māori response.

Opposition to GM food is strong globally. Kinnear (2004:111) demonstrates that GMO food products are designed to reduce production costs. Organic food industries are in direct competition to agriculture's streamlined inventions where food is shipped internationally and fossil fuels are adopted in production contributing to a poor carbon footprint (Kinnear 2004). Cross-contamination of organic crops is feared by organic growers, and has already resulted in some growers losing organic certification (Kinnear 2004:116).

Shiva (2014) argues that the genetically modified organism (GMO) food industry is failing by creating negative impacts that result in a reduction in vitamin capacity:

Golden rice is 7,000 percent less efficient in providing vitamin A and GMO bananas will be 3,000 percent less efficient in providing iron than alternatives available in our rich but rapidly disappearing biodiversity. (Shiva 2014:278)

GMO products claim to produce high yields, however, Shiva (2014:280-281) instead dismisses this, calling it a "failure to yield", citing a study in India which notes a drastically different yield to that advertised by the "emperor of GMO's", Monsanto. The author highlights other dubious attributes of the capitalist entity Monsanto, such as their sponsorship of the World Food Prize 2013, in which Monsanto awarded itself (Shiva 2014:280). Activities like this suggest a monopolistic approach by the companies that develop, to own, technologies like GMO for crop enhancement. Farmers have become dependent on Monsanto products, lured into debt, resulting in a trend of suicides in the Indian "cotton belt" (the state of Maharashtra), where in 1995 alone there were 1083 suicides (2014:288-293). The trickle-down effect shows no mercy to the farmers or consumer of Monsanto products. The company's character is in doubt, and leaves a negative impression on genetically modified food sources. In 2016 pharmaceutical-crop-science giant Bayer purchased Monsato, creating a mega merger that suggests a monopoly of the market (Kumar 2019). 
Jeffrey Smith (2003) lists possibilities of what might "go wrong" in the process of genetically modifying foods. One example being "horizontal gene transfer", in which GM food contains an antibiotic resistant marker consumed by humans, risking absorption in gut bacteria, thus, transferring the genes of a food product to a human (Smith 2003:59). Proponents of GM food have responded saying that this is a matter of fact for non-GM food as well, while admitting that there is an element of risk in absorbing new gene, the vast diet of humans means that exposure to foreign DNA is not unusual (Fedoroff and Brown 2004:158-159).

Locally, investigative journalist, Nicky Hager, published a book in 2002, Seeds of Distrust, an exposé on what he calls a cover up of a GM crop released in Aotearoa New Zealand. In late 2000, he claims, through the use of various sources that GE-contaminated sweet corn seeds were planted in several provincial growing regions, harvested and sold to consumer brands such as Heinz and Watties (Hager 2002). Under HSNO, it is illegal to release GM crops without being granted to do so by the EPA (HSNO Act 1996; MFE 2004; Hager 2002:25). Hager (2002:91-103) goes on to say that the then Labour government formulated a cover up of the released crops using PR strategies, resulting in $15,000 \mathrm{GE}$ corn plants being sold in supermarkets. Although this event is not overtly cited elsewhere in the literature, its bold claims and lengthy argument sanction its mentioning.

\section{A Potential Benefit in Pest Management?}

Organic production in viticulture is argued to increase biodiversity and pose less risk to vines (Sowman 2017:13). Sowman (2017:16) argues that there is no difference in yield between organic and non-organic production, reiterating the point previously made by Shiva. Elsewhere, in organic viticulture, Te Whare Ra Wines, have utilised buckwheat planting between vines to attract beneficial pests like lady bugs, wasps and hoverfly's (New Zealand Wine n.d.). Their organic approach to pest management is of great interest to this thesis, as they seem to favour wasps, and other 'pests' to eradicate potentially more damaging insects to the vine. 
Phil Lester (2018) also acknowledges that wasps can play a part in pest control and pollination, alongside controlling herbivore pests, like the great white butterfly. At one stage commercial exports of wasp larvae to Japan for human consumption occurred, however, health and safety issues became too great a concern to continue (Lester 2018:80). The same venture now operates a pest control business in which they acknowledge some loss of income if wasps became controlled through other methods (Lester 2018:80). Lester (2018:19) questions: "[w]hose value system should we use to calculate the effects?"; issuing the term net harm to describe how calculations are made and whether the negatives outweigh the positive. This has great relevance to the participants in this thesis.

\section{Tikanga Māori and GM}

...Life forms have a whakapapa back to Atua (the Gods), and each life form has its own mauri, including genes. (Hutchings and Reynolds 2004:6).

The Māori scholarship on GM identifies several values and tikanga that are compromised of: whakapapa, mauri, kaitiakitanga, tino rangatiratanga, and tapu. This section elaborates these concerns and highlights key literature.

\section{Kaitiaki Intersections}

Kaitiakitanga is fundamental to Māori, reflecting environmental wellbeing. Central to kaitiakitanga is mahinga kai, a natural resource for food cultivation, providing sustenance for people and cultural identity (see Mutu 2010). Principle to kaitiakitanga is the protection of mauri (life-force) (Hutchings 2004:186). Disruption of mauri is a concern to Māori (Hutchings 2004:184). Furthermore, It is argued that Māori view genetic material (including DNA, cells, tissue) to be taonga (treasures), therefore, necessitating the protocols of kaitiakitanga (Beaton et al. 2017:346; Gibbs 1996 cited in Hutchings et al. 2004:7), and requiring further kawa (protocol) (Hudson 2016a). Taonga also incites the Article 2 of Te Tiriti o Waitangi ${ }^{5}$ which states Māori have control over (McFarlane and Roberts 2005; Te Tiriti o Waitangi 1840). Similarly, tino rangatiratanga (self-determination) is undermined by the threat of GE to

\footnotetext{
${ }^{5}$ The Māori text of the Treaty of Waitangi.
} 
tikanga Māori, which denies Māori the ability to act as kaitiaki (stewards) for the environment (Cram 2005:55). Tino rangatiratanga also has great relevance to the Treaty partnerships (Satterfield et al. 2005:82), attempted by government policy. Kaitiakitanga thus intersects on multiple cultural concerns for Māori. GM discussion is subject to the concerns of kaitiaki, as demonstrated in the historical resistance to these technologies.

\section{Whakapapa}

Principal to the discourse on Māori opposition to GM is the disruption to whakapapa. Whakapapa has a clear cross-over in genetic research as genealogical links are at the core of its science. Several authors cite the importance of whakapapa in the literature (Hudson et al. 2007; Hutchings and Reynolds 2004; Roberts et al. 2004; Taupo 2012), to be explored in this section.

Baker (2010:119) found that participants in her thesis study thought GE disrespected whakapapa and undermined it. Roberts et al. (2004) explored whakapapa through relationships to the non-human, showing intersections of food, animals, and gods. Hudson et al. (2016b:346) notes that disturbing whakapapa is a "...culturally significant activity". Harmsworth (2004:13) recommends collaborative research on whakapapa and GE, alongside the "development of cultural value-based frameworks; Māori participation in research: increased capacity of Māori to engage, contribute and lead" so that Māori can make more informed decisions.

Several instances of culturally based frameworks have since appeared. Hutchings et al. (2017) identify tools that have been developed by Māori academics to help facilitate understanding of tikanga Māori concepts such as mauri. Kepa Morgan (2007 cited in Hutchings et al. 2017) created the Mauri Model which quantifies the impact of activities on the mauri of communities and ecosystems by a points system. Ian Ruru (2015 cited in Hutchings et al. 2017) developed the Mauri Compass which measured mauri in 12 'points', four of which were determined by tangata whenua only, and eight that utilised Western science paradigms. Hutchings et al. (2017) advocates for the usage of these kaitiakitanga tools in agribusiness, citing the potential cultural well-being 
and economic benefits they create. These tools show that Western standards of measurement fail to account for tikanga, and that Māori have innovated new ways to conceptualise values for a broader audience.

\section{Māori Perceptions of Biotechnology}

In this section some of the key studies concerning Māori and GE, GM, and biotechnologies are identified and summarised.

Te Momo (2007) conducted a study on Māori perceptions of biotechnologies, in which she concluded seven viewpoints:

- Purist Māori view (believed there was a similarity in GE and GM to traditional Māori narratives like Tāne Mahuta who created forests from mating with rocks and trees)

- Religious Mãori view (found biotechnologies to be 'sinful' and a violation to Christian beliefs)

- Anti Māori view (believe GM development is based on economic factors that will not benefit Māori)

- Pro Māori view (expressed potential benefit in medical use and the environment)

- No Māori view (disengaged and uninformed on issues, preferring to leave this discussion to community leaders)

- Uncertain Māori view (unconvinced and cautious of GM)

- Middle Māori view (holding several viewpoints, and a fluid position). (Te Momo 2007:1181-1182).

In her study, a wide catchment of participants are seen, including: doctors, community organisations, academics, and students (Te Momo 2007).

Baker (2012) developed the Korowai Framework, using values from the ART confederation (Te Ātiawa ki Whakarongotai, Ngāti Raukawa ki te tonga and Ngāti Toa Rangatira), specifically on ngārara (insects), to assess GE. Key values found were: sustaining life, relationships with people and the environment, indication of health by toho (signs), restrictions of tapu (sacred) things, and holistic protection "of the environment and people" (Baker 2012:91). GE conflicted with these values, and participants felt uninformed on GE issues (2012). Additional concerns included: bioprospecting, lower quality food products, poor engagement with Māori communities, an undermining of whakapapa, and a "loss of power and control to mātauranga Māori about whakapapa" (Baker 2012:92). 
Roberts and Fairweather (2004) conducted a large study (99 participants) on South Island Māori (most participants were Ngāi Tahu descendants) perceptions of biotechnologies. Their study found opposition among the participants, citing concerns of trust in science, poor information, concerns of negative effects to people and the environment, and conflicting tikanga values (2004). Two categories emerged in the research: "one largely pragmatic and the other more subjective, and apparently culturally based", of which cited concerns to tikanga (2004:74). In addition, the influence of news media, and even science fiction horror was discussed (2004:69-70)

Taupo (2012) found different viewpoints on biobanking and genetic testing in a study with three Māori groups: rongoā practitioners, lawyers, and members of the Church of Latter Day Saints. DNA was seen as whakapapa and taonga (2012:36). Additionally, genetic information reflected the collective group, not the individual whakapapa (e.g. whanau, hapū (sub-tribe), iwi), thus, consists of implications if being used or tested (2012).

Māori opposition to GM is exemplified in a 1999 application to the ERMA by AgResearch, a Crown Research Insitute (CRI). AgResearch sought to test genetically modified cattle, containing human genetic material in the Waikato region (Cram 2005; Satterfield and Roberts 2008). Ngāti Wairere, local iwi to the rohe (tribal boundaries), strongly opposed the application, calling it, "...a direct challenge on our tikanga and kawa..." (Amohanga 1999 cited in Cram 2005:60). Satterfield and Roberts (2008:207) argue that this case showed the inability for policy to deal with Māori spiritual beleifs like mauri. In another instance Māori were manipulated by companies in attempts to gain consent. Cherryl Smith (2006:204) argues this manifested in an example from Tauranga, where Selbourne Biological Services and PPL Therapeutics coaxed one of several iwi they were trying to gain consent from, so they could mix human DNA with sheep. McFarlane and Roberts (2005:554) suggests otherwise, explaining a compromise was reached by Māori due to the potential health benefits in the research. Concerns over mixing DNA meant a meticulous disposal of the animal to prevent it entering the food chain or local waterways 
(2005:554-555). Other opposition by Māori can be seen as early as 1993 when the Mataatua Declaration was signed by Mataatua iwi, opposing GM (C. Smith 2006).

Biobanking, which involves the storage of genetic material use in health research is of concern to Māori (Hudson et al. 2016a). Hudson et al. (2016a:347) states that genetic information is "...a highly valuable strategic asset to Māori". Hudson et al. (2007:44-48), argues that Māori could benefit from genetic research through health focused research like envirogenomics, which examines environmental and hereditary genetic factors that could influence diabetes and other disproportionate diseases Māori face. Hudson et al. (2016a:345) describes the "cultural logic" for biobanking and genomic research as one that intersects with concepts such as: taonga, takōha (gifting or donation), kawa (principles and protocols), tikanga (the correct way of doing), mauri (the physical health of a living or inanimate object), wairua, mana (control and prestige). Hudson and his fellow researchers publish a distinctly different framing of Māori and GM, emphasising a potential benefit to Māori, rather than dismissing genetic research. In doing so, they seem to advocate for the adoption of biotechnologies. Tikanga issues that are previously identified are re-framed to better understand the use of biotechnologies, contrasting other studies. Re-framing tikanga is critiqued by Hutchings and Reynolds (2004:19-20) who argue that tikanga has been reinterpreted by certain groups who are incentivised to validate uses of genetic modification. Other concerns raised by Māori include accessibility of GE benefits (for example, cost of technology) (Baker 2012:93). If not mediated fairly, the "roll-out" of technologies could further enhance the inequities Māori face already (Shuzle and Green 2017).

Hudson et al. (2016b) found any research on genetics is considered tapu (sacred) by Māori due to the interaction with taonga. Mead (2003:337) considers the affects to tapu in GM with an example of fish genes being transferred to a tomato. He questions the domains of atua (gods) that these two resources come from: 
...fish are under the mantle of Tangaroa, and plants under tāne. Is the result to enhance the tomato or to degrade it? Has the tapu of Tangaroa been damaged in the transfer? Probably, one would say, not much. (Mead 2003:337)

Technically there is a breach of tapu, but it is not as severe as breaching the tapu of Tūmatauenga whom conquered Tangaroa (2003:338). The scenario highlights the complexities in considering atua narratives and the tikanga they hold. Also suggested is a fluidity of tikanga when considering contemporary issues.

Biomedical research has been critiqued in literature. Hallan (2004) argues that biomedical research is driven by neoliberal policies, resulting in strategic research and targeted funding. Hutchings and Reynolds (2004) critique academic output on GM discussion with Māori as being influenced by research funding and career incentives. While Rogers-Hayden and Campbell (2003) highlight the 'knowledge economy', where research funding is based on private sector values, meaning that research with the most economic benefit is greenlit - biotechnology and genetic modification is recognised to be a growing sector for investment. Recent funding decisions like August 2017 when the New Zealand Government announced a \$35 million investment for genomic research, which saw the formation of Genomics Aotearoa, a collective of research institutes collaborating on genomic research (Ministry of Business, Innovation and Employment 2017b). New pathways in scientific research will need to consider the public perceptions in these advancements in order to prevent backlash like that seen in the era of the RCGM.

\section{Tikanga Rangahau}

How research is conducted and by who appeared as a subtheme in the literature review. Aroha Mead (1998:24) points out that research has financial incentives, of great concern is the intellectual property rights that can be reigned over biotechnological inventions. Kinnear (2004:111) acknowledges that there may be some benefits with biotechnologies, however, research into these spheres "...must be publicly funded, independent and strictly controlled to assess long-term possible affects, especially of transgenic organisms". In a 
mixed-method study, Te Mata Ira, a research project funded by the Health Research Council of New Zealand (2012-2015), it was found, unsurprisingly, that iwi desired consultation on any biobanking activities in their communities, and that consent to use was attained at all stages of research (Beaton et al. 2017:347). This thesis, in some ways, speaks to these concerns, as it is publicly funded by the National Science Challenge (NSC). Furthermore, an impartial, critical, and object stance is assured by the detachment this thesis has from the primary research outputs of the NSC.

The purpose of research is paramount, and how it might serve Māori is a priority (Beaton et al. 2017:348). Baker (2012:88) notes GE that took place within her tribal boundaries highlighted issues in consultation, communication, partnership, and no attempt to forge relationships with traditional land owners. Baker (2012:97) links GE and Māori values to the struggle of decolonisation.

Observed in the literature is great suspicion and wariness about the intentions of genetic research. GE is said to be one of the biggest threats facing Māori in the early 2000's (Cram 2005:51). Biotechnologies ultimately stem from reductionist thinking, which fails to consider alternative systems of value and beliefs that Indigenous people live by on a daily basis (A. Mead 1998:24). GE consultation with Māori has been described as predetermined in its outcomes, framed in a Western science and economic context, dismissing alternative realities (Jackson 2007:179). This is a reflection of the "power to define" (Ibid.), a trait of the coloniser. More than a decade since these arguments emerged, do Māori still feel the same in the face of global warming and other contemporary issues?

\section{SLO}

The issues of consent in genetic research cited in the case of biobanking, in combination with issues of consultation and how research is conducted are analogous to the social licence to operate (SLO) discourse. SLO has origins in mineral extraction and is about gaining community acceptance and permission 
to conduct business (Owen and Kemp 2013; Edwards and Trafford 2016). Themes located in SLO theory include: trust, engagement, partnership, openness and transparency and scale (Edwards and Trafford 2016). Hall and Jeanneret (2015 cited in Edwards and Trafford 2016) say SLO is an extension of corporate social responsibility. In Aotearoa, SLO has been considered in industry responsibility, of particular relevance to this thesis, farmers have been suggested to think about their brand narrative to tackle sustainability criticism (Ibid.). Ruckstuhl et al. (2014) makes the argument that in Aotearoa New Zealand, Te Tiriti o Waitangi is the original social license to operate in Aotearoa New Zealand. It is further suggested that Māori have always been engaged in SLO, evidenced in the history of resistance against colonial and corporate forces (Ibid.). Most recently, SLO has been utilised to gain perceptions of government and industry, revealing trust can be influenced by media and communication of information (Edwards et al. 2019). Consideration of SLO has also been incorporated into discussion on whether gene editing technologies might be the "answer" to pest control issues in Aotearoa (Dearden et al. 2018). The literature SLO forms another reason to explore acceptability of biotechnologies.

\section{Conclusion}

The Māori economy is a bourgeoning space that operates in a capitalist framework. The literature shows a desire to move beyond capitalism. Recently, Māori academics have been drawn to the diverse economy framework, due to its accommodation for Māori values, reasoning its use in this thesis. Simultaneously, scientific advancements, which hold historically negative connotations for Māori, push forward internationally. Previous research shows Māori concerns are rooted in tikanga and cultural property. However, the booming Māori economy equates to Māori businesses operating in industries speculated to benefit from biotechnologies. Are Māori business concerns the same as the previous research on Māori and biotech, some 10-15 years ago? Or do they voice other concerns? 


\section{Chapter Two: Methodologies}

\section{Introduction}

To understand Māori business owners' perceptions of biotechnologies in pest wasp management, a mixed-method kaupapa Māori methodology was used. I first discuss how kaupapa Māori literature informed the tikanga of my interviews. I then reflect on challenges in conducting the research. Finally, I discuss the data analysis in relation to a diverse economy framework.

\section{Positionality}

Understanding my positionality as the researcher is paramount to the research process, and is a marker of quality in qualitative research (Lincoln 2002). Firstly, I understand that I am in the privileged position of being the researcher and not the researched, meaning that I have set the agenda; the research it is not co-created. This has the potential to kindle parallels to the early forms of research by the coloniser, which has seen damage caused to Indigenous people worldwide (L. T. Smith 2012; Pihama 2016). Kaupapa Māori methodology mitigates this, and enables culturally safe measures to be taken throughout the research.

Employing a kaupapa Māori approach to research requires the researcher to consider their whakapapa, identity and the tools of the academy. I acknowledge my Māori whakapapa to Ngāi Te Rangi in Tauranga Moana. I am aware of the cultural capital, gained by studying Māori studies at a University; but also, my incapacities, having not "grown up on the marae" or in te ao Māori - a reality that can be located in the continual flow-on effects of colonisation and urbanisation. As Coombes (2013:75) identifies, internalised oppression of culture and identity can be seen in the generations before me. My identity is combined with no previous experience or professional insights to the industries in scope of interviews. I come from a diverse academic and professional background. My first degree was in music, and before I found Māori studies I dabbled in cultural studies. Therefore, I undertake this thesis with a mixed skillset, one where I continue to grow as a learner of tikanga and te reo Māori, 
among many other facets in this research area, as opposed to entering the field as a self-proclaimed 'expert'.

I am also fortunate to have been supported in a team environment during this thesis, having worked side-by-side with Alan King Hunt, a fellow master's student who is investigating perceptions of biotechnology among religious Māori. We have travelled together and co-presented at international conferences on research in this field. We have both attended seminars and workshops on 'gene editing' facilitated by the Royal Society Te Apārangi. For the most part, our supervision hui with Dr. Ocean Mercier have been conjoined, providing a space to soundboard ideas and challenges along the thesis journey.

\section{Insider/Outsider}

The insider/outsider concept is a binary used frequently in research to open up ways to think about the researcher's relationship to the kaupapa (topic) or participants in any given project. This is complicated by the use of a kaupapa Māori methodology, as Linda Tuhiwai Smith explains:

Indigenous research approaches problematize the insider model in different ways because there are multiple ways of being either an insider or an outsider in indigenous contexts. (L. T. Smith 2012:138)

In identifying as Māori, one might be steeped in tikanga and te reo Māori, have connections to their marae; or conversely, never been to their marae, or uncertain of their whakapapa to hapū and iwi. This does not make one or the other less or more Māori. Taken for granted, these discrepancies, if unidentified can illustrate a tint of ignorance in the researcher. Therefore an acknowledgement of disparities between myself and participants should be considered.

In this study, I mostly occupy an outsider status. My insider status is only visible in my keen interest in viticulture, culminating from years of work in hospitality. This interest did help to generate industry relevant conversation during first interactions, but quickly became irrelevant when transitioning to biotechnologies. 


\section{Kaupapa Māori}

This thesis is grounded in a kaupapa Māori methodology. Before examining the intricacies of this approach to research, the qualitative methodology that is core to kaupapa Māori methodology will be explored.

Qualitative research involves the studied use and collection of a variety of empirical materials - case study, personal experience, introspection, life story, interview, artefacts, and cultural texts and productions, along with observational, historical, and visual texts - that describe routine and problematic moments in individuals' lives. (Denzin and Lincoln 2011:3-4)

Qualitative research is an ideal means to gain in-depth insights on complex issues through one-on-one interviews (Hennick et al. 2011). It differs from a positivist research paradigm that is traditionally rooted in "hard science" (Hennick et al. 2011), critiqued by Indigenous scholarship (see L. T. Smith 2012). Whereas, qualitative research seeks and ascribes meaning to nuances and detail. Diverging from quantitative studies that measure specific data, which risks missing points of concern in researched communities like that of the census which has subjugated Indigenous peoples needs in the past (Anderson and Kukutai 2016). In contrast, qualitative research takes on an interpretive paradigm so that it "...recognises that reality is socially constructed as people's experience within social, cultural, historical or personal contexts" (Hennick et al. 2011). Given the scope of this research, and the complicated nature of questions, qualitative research is an unrivalled grounding for this thesis.

We have been written about, talked about, photographed, medically dissected, biologically and anthropologically classified, and our bones have been displayed in museums. (Teaiwa 1995:59-60).

Qualitative research has evolved over time to include minority perspectives, responding to historically damaging research on Māori and Indigenous peoples, resulting in 'scholarship' that does not fully recognise Māori views, and risks misuse of information - in some cases for commercial benefit (Bishop 1998; L.T. Smith 2012). Hegemonic powers, derived from colonial roots, continue to have influence in all aspects of society (Maaka \& Fleras 2005:284). Indigenous ways of researching actively decolonise the research process and provide a platform for transformation (L.T. Smith 2008). A kaupapa Māori approach 
builds on other empowering developments being made for Māori in education and communities (Hutchings 2011); and provides a way of 'speaking back' to the academy (Tengan 2005). Rooted in the Māori renaissance and Māori resistance movements of the 1970's-1980's (Durie 2012; Bishop 2008), it provides a Māori perspective in ethics that has been applied to te reo Māori, law, health and research (Durie 2012). Kaupapa Māori methodology is - or should be - a conventional means of inquiry when researching with Māori to ensure cultural safety.

Defining kaupapa Māori can be a challenging exercise, and in doing so, may result in the need to justify its use to the mainstream academic realm (Barnes 2000). A wider context must be acknowledged to assure validation to the academy. The obvious point to make is that colonisation is different everywhere but has created inequalities that are entrenched in society for Indigenous peoples worldwide (McCaslin \& Breton 2008). Likewise, decolonisation does not have a unanimous definition among researchers (Swadener \& Mutua 2008), however, the re-centring of Indigenous concerns and views is a key aspect that kaupapa Māori methodology contributes to decolonisation - it "...is a legitimate way to represent and research our 'stories' today" (Lee 2009).

Professor Linda Tuhiwai Smith (2015:358) best explains Kaupapa Māori to be research in which "...Māori language, knowledge, and culture are valid and legitimate, and has a standpoint from which research is developed, conducted, analysed, interpreted, and assessed". Making kaupapa Māori tangible, it can be realised as:

1. Related to 'being Māori'

2. Is connected to Māori philosophy and principles;

3. Takes for granted the validity and legitimacy of Māori, the importance of Māori language and culture; and

4. Is concerned with 'the struggle for autonomy over our own cultural well-being'. (G. Smith 1990 cited in Smith 2012:187)

The ways in which Kaupapa Māori manifests in this thesis are visible in the interview process. Interviews incorporated tikanga Māori values in various 
ways including koha (gifting), kai (food), and karakia (traditional incantations). This will be detailed later in this chapter, but firstly, developing a mixedmethod approach is discussed, which is the subject of following section.

\section{Constructing a Mixed-Method Approach}

In this thesis, Likert ranking exercises, were adopted during the interview process, contributing to a mixed-method approach. In this section, the practicalities of incorporating mixed-method tasks within qualitative interviews are discussed.

Denzin and Lincoln (2008:12) classify mixed method approaches to research as a descendant of science-based research that "...presume[s] a methodological hierarchy in which quantitative methods are at the top...". Qualitative research has a history of politics with "science-based research" (i.e. quantitative approaches) (ibid.). Additionally, quantitative studies have historically been associated with positivism, research rooted in western science methods of investigation (Anderson and Kukutai 2016). However, in mediation of these tensions, this study privileges a qualitative kaupapa Māori approach. Including Likert ranking exercises is intended as a conversation starter with participants - not a quantitative revealing exercise. Participant numbers further highlight this detail, as for a truly quantitative study to take shape, larger participant numbers would be required.

As Cram and Merten's (2015:94) highlight, mixed-methods can provide multiple ways of accessing views in data collection, and creates different ways to present data. With this in mind, the intention of incorporating Likert exercises is to help collect views by giving participants another way of expressing themselves.

The aims of this thesis are to understand what biotechnologies Māori businesses might find acceptable in pest management, and on what conditions. Likert's assists this by forcing participants to make decisions on biotechnologies. Additionally, each interview is made uniform by including the same Likert exercises. In this way, a 'scene' is set at the beginning of each 
interview that provides a grounding for qualitative questions to follow. Furthermore, prompting participants with visual aids were seen to be beneficial at interviews. To explain this further, a breakdown of how Likert scales were incorporated into the interview process follows shortly.

Influencing the decision to incorporate Likert's in this thesis was previous research conducted by my supervisor Dr. Ocean Mercier and colleague Alan King-Hunt. In their study, Likert ranking exercises were adopted alongside $\mathbf{Q}$ Method (Mercier et al. 2018). Likert ranking scales work by asking participants to rank items in order of preference (e.g. from least acceptable to most acceptable). Calculating scale value means, medians, and standard deviations, give a sense of interviewee impressions across the group. It should be noted that due to small participant numbers in this study, the figures produced are indicative rather than representative.

\section{Identifying Participants}

The scope of this research project requires participants in Māori businesses that have experience or opinions in pest management, with an emphasis on wasps. Based on the economic impact calculations in the study conducted by Maclntyre and Hellstrom (2015), the industries that were deemed most relevant and occupied by Māori are: apiculture, agriculture, and horticulture. Forestry and tourism could have also been included in this project, however, the interaction with wasps appeared to be less common with limited economic impact. Therefore, a focus on the more directly affected industries was made.

As mentioned, Maclntyre and Hellstrom (2015:20) found no economic impact of wasps to viticulture. However, elsewhere wasps are described as beneficial to organic wine production (New Zealand Wine n.d.). This was reiterated by comments from potential viticulture participants at networking events. Consequently, the addition of viticulture was made to provide an understanding of these nuances. The final participants were all food and drink producers from: horticulture, agriculture, apiculture and viticulture. 
It should also be noted that one participant was Pākehā, acting in an industry specific role, speaking on behalf of the Māori brand that he worked for. I do not see any clear conflicts to embracing the kōrero of this participant as they are an expert in their field, with a genuine long-term relationship with the brand. It could be argued that this particular interview sits outside a kaupapa Māori framework. However, given the specificity of some questions, an expert in pest management strategies is key to gauging perspectives. The participant acted appropriately and sensitively to culturally specific issues. When uncertain of an answer, they recommended speaking to another member of the organisation. Additionally, their embodiment of the brand, gives their kōrero (talk) mana (prestige), in that the brand values are referenced in their answers. All other participants self-identified as Māori.

The inclusion of a Pākehā participant within this Kaupapa Māori designed research can be interpreted as an exception. Te Momo (2007) makes explicit that only Māori participants were interviewed in her Kaupapa Māori study. Thus exploring the inclusion of someone outside of the cultural boundaries in a kaupapa Māori methodology is required. Jones (2012) eloquently expands on the 'for Māori, by Māori' parameters that Kaupapa Māori appears to cement by arguing that the meaning should not be interpreted as exclusionary of Pākehā; instead it is about re-centring the research to be Māori led, on Māori terms and worldviews. With this in mind, the inclusion of a Pākehā participant, in relation to the thesis topic, is granted by not only me the Māori researcher, but also by the Māori business they work for and represent in their kōrero.

My encounters with kaupapa Māori methodology in this thesis has caused reflection on its practicality. Alice Te Punga Somerville (2011 cited in Bargh 2011) has signalled that kaupapa Māori as a methodology is not always liberating to Māori researchers. Bargh (2011:59) has also demonstrated that it is sometimes not suited to particular types of research, like research without a "resistance stance". The reflective nature of research poses room for evaluation and alteration going forward. In this sense, I have sought a fluid and 
adaptive kaupapa Māori methodology that is culturally safe for all participants, and myself.

\section{Whakawhanaungatanga: Getting to Know Participants}

'Participant recruitment' is a key phase to social research. "Gaining entry to the field of study is something which every researcher has to negotiate" (Irwin 1994:35). In a kaupapa Māori setting, a more inviting way of conceptualising this process is through whakawhanaungatanga (establishing relationships). Pihama (2016) emphasises the importance of whakawhanaungatanga, relationships, and whakapapa. Cram (2001:44) states the importance of trust and relationships during research process, emphasising that these are created through prior meetings and time spent in communities or with people. As Linda Tuhiwai Smith (2012:158) says, "[n]etworking is a way of making contacts between marginalized communities". Thus, implying an empowerment can be garnered in the process, further inciting the transformative nature of kaupapa Māori research. These are values I have carried throughout the participant recruitment phase.

Due to my limited business network at the beginning of this project, the development of relationships was crucial to the success of this project. I made a conscious effort to meet potential Māori businesses of interest by attending hui and engaging with business networks. The guiding principle of whakawhanaungatanga thus informed the networking process.

Applying whakawhanaungatanga to the invitation phase in this project also occurred in written communication. Email invitations to participate in the project were tailored to each potential interviewee. Throughout the project, an effort to minimise the use of "cold calling" ${ }^{6}$ was made. Emails addressed to potential participants featured a brief mihi (greeting) and introduction, stating my whakapapa and the project purpose. Email invitations were usually sent after a phone call or an in-person meeting. Some invitations were sent as a "cold call" due to not having any other means of contact. In other situations,

\footnotetext{
${ }^{6}$ Making contact without having met before.
} 
an invitation to participate was sent without previous contact, but a mutual connection was mentioned in the email, attempting to build whakawhanaungatanga.

Due to the overwhelming amount of potential participants in this study, and several suggestions for potential participants, tracking communications became essential. I created a spreadsheet to keep track of months of communications with potential participants. The spreadsheet contained a contact database, and log of communications (i.e., email, meeting, phone call) and notes of what took place. The advantage of a meticulous tracking of interactions with participants assisted my interview scheduling, and tracking of consent forms and information sheets.

I attended various networking events and hui throughout the participant recruitment phase. The first event I attended, was a local Māori and Pasifika breakfast hui hosted by Te Awe Wellington Business Network where I tried to meet local small businesses that might be within the scope of this project. Although no businesses at the hui were within scope of this thesis, it was still a positive experience that strengthened the clarity of my 'elevator pitch' and gave me confidence to speak with others in a network setting.

An important hui that I attended was the Mānuka Symposium in June 2018, hosted by the UMF (Unique Mānuka Factor) honey association at Buddle Finlay Law. At this event I was fortunate to meet bee keepers who agreed to take part in this thesis. The hui also shed light on the current issues facing apiculture, namely the Australian "Mānuka" trademark debacle that was unfolding during the thesis period ${ }^{7}$. Later in the evening, I introduced myself to Māori beekeepers who expanded on issues facing the industry, giving me some insights to their operations. Cram (2001:44) calls this "titiro whakarongo... kōrero", meaning that the researcher is listening and learning before speaking. Some were interested to know more about my thesis, while others distanced themselves, stating they would not be any help. I assured each person I met

${ }^{7}$ For context see (Roy, E. A. 2018) 
that their kōrero and whakaaro (thoughts) were important, and anything they had to say would be interesting to the project. These interactions highlighted that biotechnology is a potentially intimidating to those who may hold valuable opinions. This made it difficult to recruit participants as people often felt that they could not contribute to the project. The recruitment process in itself was an experiment in science communication on my own part, in that I was required to explain the relevance of biotechnologies to small business owners, and why I was interested in their thoughts on pest management issues. Nonetheless, after following up with emails I managed to confirm two interviews with beekeepers.

Another event that I attended was Winetopia, an annual wine tasting event in Wellington, where I was fortunate to meet several Māori winemakers. Attending this event was a valuable interaction with a winery I had already been trying to contact but were yet to respond. In meeting them, they were very friendly and apologetic for not responding, and were keen to participate. This was a reoccurring theme during the participant recruitment process. On several occasions I was struck with no reply from emails or phone calls to businesses of interest. However, sometimes it would take a third or fourth communication before I was redirected to the right person. The challenging nature of this was not in the lack of communication, it was simply that these are businesses are made up of busy people. Navigating business schedules while planning my own work and life commitments was a challenge throughout the research.

Misunderstanding and confusion about the project, and who I was, occurred several times during the participant recruitment phase. Often people thought I was a scientist because of the involvement of biotechnologies. Additionally, people frequently told me that they would be no help to the project, suggesting that the invitation to participate in the research was only for people with a science background. This was an unfortunate and difficult thought process to overcome and explain. It also highlights the potentially alienating nature of biotechnologies, as a subject that is reserved for scientists. 


\section{Likert Ranking Exercises}

As mentioned, two Likert ranking exercises were used as part of the interview process. These were designed to 'set the tone' and direction of questions that followed and gain an immediate 'pulse' on the positionality of participants. The first Likert ranking exercise (to be referred to as LRE1 from hereon) that participants completed queried which animals or insects they considered to be pests. The second Likert (to be referred to as LRE2 from hereon) asked what methods of pest management they would be in favour of or against.

\begin{tabular}{|c|c|c|c|c|c|c|c|c|}
\hline \multicolumn{2}{|c|}{$\begin{array}{c}\text { Disagree (least } \\
\text { concerning) }\end{array}$} & & & & & & \multicolumn{2}{|c|}{$\begin{array}{c}\text { Agree (most } \\
\text { concerning) }\end{array}$} \\
\hline-4 & -3 & -2 & -1 & 0 & 1 & 2 & 3 & 4 \\
\hline
\end{tabular}

Figure 1 Likert Scale Response Continuum.

Both LRE1 and LRE2 utilised a numerical response continuum called 'horizontal ascending', meaning the scale ascended from left to right (Maeda 2015). As pictured in figure 1 , the scale ranged from -4 to +4 , with a 0 mid-point. Consequently, the greater a negative number, the stronger the disagreement; the polar opposite being ascending numbers in the positive. 0 can be interpreted as a neutral number, halfway between the most positive and negative numbers. At each interval of the scale, a blank square or box is located for participants to place items on. This part of the scale is defined as a response continuum hereon (see figure 1).

Participants were given nine "statements" on small pieces of paper (to be referred to as stems hereon) to arrange in order of preference on the response continuum. Each stem was required to be placed on a single degree of the Likert scale. Participants were not allowed to leave any square blank on the response continuum, or, place two stems on one degree of the scale.

LRE1 asked participants to rank perceived pests to their business on the response continuum ${ }^{8}$. The pests allocated to this exercise are identified by the PF2050 campaign as threats to New Zealand biodiversity. These are: wasps, possums, stoats, rats, feral cats, rabbits, and the great white butterfly

\footnotetext{
${ }^{8}$ See appendix 5 for ranking exercises that were presented to participants.
} 
(Department of Conservation 2019). Images of the pests were incorporated on the stem, as depicted in Appendix 5. Some of the images have the potential to be interpreted as being somewhat emotive due to the depiction of animals killing native birds. However, these images are endorsed by DOC and PF2050, and visually stimulate interview questions to contextualise pest management issues.

In addition to the pests identified by Predator Free 2050, I added two blank stems for participants to write a pest that they perceived to be an issue. These are referred to as Option A and Option B. This was an experimental adaptation to the previous work of Mercier, King-Hunt and Lester (2019), with the intention to give participants a chance to air any concerns that may have been missed by PF2050, and scope of the project at hand. It also allowed them to rank their nominated pests against the PF2050 'official pests' of concern. Thus, the exercise has the potential to show new pests that participants regard as more concerning than those set out in PF2050. Additionally, given there were technically four different industries that participated in this research, the industry specific data may be of interest to other researchers. As it will be shown in the results, LRE1 revealed that not all of the pests used in the exercise were in fact considered pests. On the contrary, some were desired, even the most contentious pest of them all - wasps.

LRE2 was geared towards finding out the degree of acceptability of the five novel biotechnologies that this thesis addresses, and how participants feel about their potential deployment. In addition to the five novel biotechnologies subject to this thesis, other more conventional techniques of pest control that participants may have had experience with were included in the mix. The nonbiotechnology categories were: manual extraction of nests, species-specific poison (e.g. Vespex®), non-species specific poison (e.g. 1080), and 'do nothing'. Participants were ask to rank the pest controls from: least acceptable; neutral; to having the potential to adopt (most acceptable) - in accordance with the nine degree response continuum (see Appendix 6). 
LRE2 was introduced to participants - and worded - with the intention to address pest wasp management. However, for several participants, wasps were not the most concerning pest, and therefore, a practical accommodation was made, where, participants were asked to re-imagine LRE2 in relation to their pest management needs. For example, a participant that has issues with pest rabbits, when faced with the stem 'manual extraction of nests' could then be paralleled as the culling of rabbits - the equivalent of manual intervention.

At times, participants found the ranking exercise difficult. This was mostly due to the limitations imposed on participants in each Likert, where they are required to make use of every option given to them. Each option has to be ranked on the response continuum from negative to positive. There is no option to not rank a pest or pest control; nor is there the option to have several pests on one degree of the continuum (e.g. stoats, possums, rats, all on +4 ). These 'rules' are in line with the methodology and previous studies using Likert exercises. From participant feedback during these exercises, several suggested their ordering to be ad-hoc, in that if they could have certain pests on the same degree of the continuum, they would. Therefore, the final rankings gathered must be taken as indicative only. The key value is to provide a snapshot of the participants in this study, in addition to prompting dialogue throughout the interview.

LRE1 and LRE2 prompted participants to think about the issues to be covered in the interview, and immediately provided talking points relevant to the questions formulated. This was a fulfilling addition to the interview repertoire that helped to build rapport with participants, which may have taken much longer to develop had the exercise not taken place. For example, probing for justification of ranking the most acceptable and least acceptable options, were effective in allowing participants to describe how they felt and for what reason.

\section{Interview Process}

In this section, the interview format will be presented with reflection on the implementation of a kaupapa Māori methodology. 
He Kanohi kitea, being face-to-face, was a tikanga adopted in this thesis. Cram (2001:43) calls he kanohi kitea the "fronting up" to a researched community, an integral part to research with Māori values or Kaupapa Māori methodology. Kanohi kitea informed multiple stages in the project. An effort was made to meet participants in person (where possible) to discuss my research before asking them to participate. This involved me attending several events during the early phases of research. Kanohi kitea was a core principle for interviews, involving travel across the country to meet with participants. Interviewing kanohi kitea is an advantage to research, where relationships can be fostered and maintained, and tikanga like hongi (pressing noses to greet) and manaakitanga (hospitality) can be facilitated. One interview took place via Skype due to time constraints and practicalities, however, I had previously met and discussed this research with the participant in person.

All interviews followed a semi-structured approach, meaning that no two interviews were the same in length or content (Chilisa 2012:205). Nonetheless a set of questions were covered in every instance ${ }^{9}$. The participant responses guided this process, as relevant points were made and tangents occurred, further discussion could be probed.

Participants were emailed a 'primer' document that contained in-depth descriptions (sourced from scientific articles) of the five novel biotechnologies subject to this thesis. The primer was originally produced by Alan King-Hunt, and then adapted to this project. A bullet-point single sentence summary was also generated for each biotechnology on the front page of this document (see Appendix 4$)^{10}$. Interestingly, the primer was only two read by two participants. While some mentioned they glanced over it; the majority had not.

Koha

A koha (gift) was given to all participants in this research project. The koha was in the form of a voucher, valued at $\$ 30$. This is on par with the current

\footnotetext{
${ }^{9}$ See Appendix 8 for interview questions.

${ }^{10}$ Due to copyright, only the front page of the primer has been included in the Appendix.
} 
recommended compensation to participants by the Human Ethics Committee at Victoria University of Wellington. The koha acknowledges the time and efforts of participants at what is considered an appropriate sum in parallel studies (King Hunt, A. forthcoming). If the koha is too great a sum then participation in this research could be interpreted as intentional payment. Being conscious of a koha value reassures that participants participated in this research on their own free will.

Mead (2003) speaks of the reciprocal nature of the koha, in that it is often tikanga for a koha to be reciprocated in the near future: a return gift. In light of this, I see the koha given to participants as a return gifting. The initial gift being their time, kōrero and whakaaro during the interviews. In addition to the return gift concept, some participants might have interpreted my travelling to them and my koha to be an initial gifting, resulting in some participants returning a koha to me in the form of their product. I was grateful to be gifted samples of honey and wine at the end of some interviews. This was a very kind and unexpected exchange during the interview process that shows a reciprocal tikanga being observed.

\section{Kai}

An exchange of kai (food) is typical in a kaupapa Māori setting. Kai has an important place in Māori society, often manifesting as a mode of tikanga. For example, the hākari (feast) at the end of a pōwhiri (welcoming ceremony) to lift tapu from manuhiri (guests) (Mead 2003:185). The use of kai in a kaupapa Māori interview embodies this tikanga (C. Smith 2014). Kai also intersects with manaakitanga, a guiding principle for how to interact with people that intersects with other concepts like mana. Although, it could also be said that kai should not be used in an interview setting due to the tapu nature of a kōrero or kaupapa. I decided to not incorporate kai into the tikanga for interviews in this project. I partly based this decision on a self-imposed principle of practicality. Due to the nature of traveling long distances to meet with participants, arriving at an unfamiliar interview locations was a reality. For example, it was hard to know if there would even be a dairy (convenience 
store) nearby, let alone a bakery, to help perform manaakitanga. Other factors for considerations were venues for the interviews (i.e., factories or worksites), which could prove difficult to assemble kai; and traveling to unknown spaces (i.e., flights out of town), collecting rental cars and driving to unfamiliar locations -sometimes hours from the airport. Among the spectrum of interview locations was a café, in which it would not have been the tikanga of the venue to bring kai. Additionally, in light of manaakitanga, I could be saving the participant from any embarrassment in being unable to assist in allowing the manaakitanga to occur (if, for example, there were no tables for food). It is these variables that amounted good reason to simplify the interview process by excluding kai.

\section{Te reo Māori}

Privileging the Māori language is a core value in kaupapa Māori methodology (G. Smith 1990 cited in L. Smith 2012). Therefore, considerations as to how it can be accommodated in research is required. My inability to speak fluent te reo Māori (the Māori language) is a setback for this principle. However, I made a conscious effort to make space for te reo Māori when possible. This is evident the participant recruitment phase, where potential interviewees were greeted with my whakapapa in a mihi, with the use of several key Māori words where possible during the body text (see Appendix 1; Appendix 2).

Te reo Māori can also be weaponised against non-speakers (Irwin 1994:33). How to remain inclusive and not exclusive during the research was also a consideration in the final composition of communications to potential participants. By this, I mean that te reo Māori is not 'taken for granted' by all Māori, and indeed, some Māori have excellent proficiency in te reo Māori, however, due to the ongoing effects of colonisation this is not a reality for all. Avoiding the notion that research participants must meet a certain 'cultural criteria' is a major ethical consideration that all research should have, in particular with Indigenous peoples. This was mitigated in the accessibility that I strived for in constructing any invitation, any phone call, email, or in-person communications that occurred. 


\section{Karakia}

In some interviews I delivered a karakia; on one occasion the participant chose to lead the karakia. Incorporating karakia reinforces my attempts to make space for te reo Māori within the project and supports a kaupapa Māori approach. The decision to give a karakia was at times based on my own level of comfort and the practicality of the interview location. In situations where I did not perform a karakia, factors contributed, for example, the interview venue was noisy or busy, making it hard or uncomfortable to deliver a meaningful karakia. Another instance karakia did not seem appropriate was during the single Skype interview. In situations where a karakia was performed, I asked first if the participant felt that a karakia was appropriate in an effort to not be culturally exclusive in my actions.

The inclusiveness towards participants and cultural reflexivity delivers a fair representation of contemporary Māori identities in business in this research. By remaining flexible in my approach to incorporating tikanga, I am able to acknowledge the diverse values participants reflect. These "...combine in different ways and with different emphasis in different definitions to define culture" (Hernandez 2013:67). Furthermore, my actions mitigate the potential for exclusivity of kaupapa Māori methodology (Mahuika 2008 cited in Hall 2014).

\section{Ethical Considerations}

This study is made possible by the freely consenting participation of eight Māori businesses located across Aotearoa in agriculture, apiculture, horticulture, and viticulture. In total, ten participants partook in interviews (two businesses had two people present at interviews). Interview length varied between $25-90 \mathrm{~min}$, in a semi-structured fashion. These businesses are profiled at the end of this section.

This project falls under the ethics application 0000024885 filed by Dr. Ocean Mercier and approved by the VUW HEC. The application extends to the two master's theses (myself and Alan King Hunt). 
Participant information sheets and consent forms were based on the ethics application. The participant information sheet states who I am, what the research is about and for, and provides contact details for my supervisor and the Human Ethics Committee at VUW (Appendix 1). The consent form gives participants the option to conceal their identities in any publications or use a pseudonym. It also makes them aware of the research purpose, and notes that data will be kept until 2025 (see Appendix 2). In all instances of potential interest in participating in an interview, respondents were emailed copies of these forms. These forms where then sent again before an interview. At interviews, hard copies of the consent form were made available to keep for each participant and myself. In some cases, participants were not concerned about keeping a copy of the consent form. Nonetheless, I emailed participants digital copies of their consent forms post-interview for their own records.

Miller and Bell (2012) foreground ethical concerns in research like informed consent, asserting that it should be an on-going dialogue between participants and the researcher, where considerations beyond the initial consent are made. Participants were given the option to receive updates on any future publications. Thus, efforts to keep participants 'in the loop' with the project were made. The consent form contained the option to review transcripts and redact any comments. Participants who selected this option were emailed back their completed transcripts for revision. In some cases participants amended words or corrected misspellings of technical terminology. No major edits took place.

Some participants opted to conceal their identities in any publication of the interview data, while others were happy to have their names attributed. To ensure a cohesive presentation of the interview data, I decided pseudonyms should be used for all the businesses involved in this thesis. Thus, all participant identities are abstract, only identifiable by region or trade. I have chosen the theme of native birds as pseudonyms. The theme seems appropriate given the conservation efforts connected to the subject of this thesis. Bird names were 
randomly paired with participants. None of the birds chosen are intended to represent any tohu (signs) or connection to particular iwi.

Here, I will briefly introduce the ten participants in this thesis (in no particular order). Paired participants represent a single business that featured two participants in a single interview.

- Kererū is a medium sized honey business located in the upper quartile of the North Island. They also provide pollination services.

- Kākāpō \& Toutouwai are a medium sized honey business located in the upper quartile of the North Island. They operate as a whānau business.

- Pūkeko is a small honey business located on an off-shore island in the lower North Island. They also run a tourism business in the same area.

- Mohua and Tūĩ are an iwi organisation in the South Island who are bee keeping, and exploring apiculture by-products.

- Kārearea is an iwi organisation in the South Island, focused on dairy farming.

- Kākā is a South Island wine maker and vineyard owner, who also works as a vineyard consultant around the country.

- Mātātā is a South Island vineyard manager for a Māori wine brand.

- Weka is a South Island iwi organisation invested in horticulture.

\section{Reflections, Limitations, Novelty}

The research design of this thesis is complimentary to concurrent research in the field, and builds on the existing research from the early-to-mid 2000's presented in the literature review, providing an up-to-the-minute 'pulse' on select Māori perceptions. It also offers a contrasting method of data collection to the previously mentioned concurrent studies being conducted by Dr. Ocean Mericer (Māori student perceptions on biotechnologies in pest wasp management) and Alan King Hunt (Māori religious and spiritual perceptions of biotechnologies in pest wasp management) ${ }^{11}$. Both Mercier and King-Hunt adopt $\mathrm{Q}$ method, which offers a different platform in data interpretation. $\mathrm{Q}$

\footnotetext{
${ }^{11}$ Forthcoming journal article and thesis.
} 
method relies on a certain number of participants (generally twelve or more) and has the benefit of data being collected in a focus group setting. One strand that stands to connect all three research projects together is the use of the Likert ranking exercises (previously mentioned). The use of the ranking exercise, in general, warmed up participants, and had them engaging with the concepts and concerns of the project immediately. They provided talking points during natural lulls or closed-ended responses. However as noted, a limitation in the incorporation of Likert's in this thesis are the "statistics" that can be derived from them. Unfortunately, these numbers lack rigor due to the modest participant numbers in this study. Instead, they act as a launch pad to discussion on the complex questions that feature in this research. Additionally, it signals individual industry feelings and concerns, particularly regarding the optional stems that gave participants a chance to mention pests they perceived to be most concerning (addressed fully in the results chapter).

\section{Data Analysis}

\section{NVivo}

I used NVivo qualitative research computer software to assist in managing the data generated from interviews. Interview content was recorded on a secure sole-purpose device (to be deleted by 2025), transcribed, and input to Nvivo software for coding. Due to the amount of data generated in a short space of time, the help of a transcribing service was sought for some of the interviews. A confidentiality agreement was prepared for the transcriber services (see Appendix 3). The remainder of the interviews were transcribed by myself. Using Nvivo, I imported transcripts, and coded the interviews, employing thematic analysis. My first attempt coding was broad and used liberally in order to catch any potential points of interest. NVivo defines each code as a "node". Around 40 nodes were generated. Proceeding the initial coding, I analysed emerging themes. Finally, a second coding took place to ensure even coding between interviews, and to prevent any areas being missed in the first wave of coding. NVivo software features digital tools to help reveal themes in data. "Matrix intersection" or "matrices" are a feature of NVivo software that helps identify 
intersecting nodes. For example, a set of nodes related to a theme like the environmental, and nodes that focus on 'economics', can be queried against each other to reveal frequent intersections. NVivo generates a table, where intersections between nodes are totalled. From this, points of inquiry can be pursed to help uncover any additional themes. Experimenting with the matrices feature in NVivo helps to find "hot spots" in the data. Other useful features of NVivo are the ability to merge nodes (if themes are similar), word searches, and visualisations of frequent words (word salads). NVivo also has the capacity to allow multiple persons to code material, however, I was the sole coder of interviews in this project.

\section{Making Use of the Diverse Economy Framework}

In the discussion chapter, the diverse economy framework which influenced the subsidiary aims of investigation in this thesis, that is to explore diverse economies in Māori businesses, will be re-introduced to make further analysis of the data. This addition to data analysis appears in the form of two tables in the discussion chapter. These are motivated by the findings of this thesis, and a table that is used in the results chapter to show connections between diverse economy activity and Māori values. Employing tables to help unpack any significance in the data informs my method of analysis in this thesis. It did not inform my approach to constructing the methodological paradigm of which this research was conducted (a kaupapa Māori mixed-method methodology). The construction of these tables will be detailed in as they appear.

\section{Conclusion}

This chapter has detailed the methodological approaches taken in this thesis. Constructing a research approach consistent with kaupapa Māori was an obvious decision given the Māori participants in this research, the previous research with Māori in the genetic and biotechnology spheres, and the potential for this subject to intersect with multiple tikanga, thus ensuring participant cultural safety is essential. Illustrated in the participant recruitment and interview process, are multiple examples of tikanga Māori, reinforcing the chosen research paradigm. Although applying tikanga was not always simple, a 
sensitive and reflexive route can be seen in my methods. The interview process has been complimented with the incorporation of Likert ranking exercises to help warm participants to this complex kaupapa, and, find additional angles to data collection, made clearer in the results chapter. The summation of these methods produces a mixed-method kaupapa Māori methodology. NVivo software has been included as a means to unpack participant's whakaaro, and maintain a rigorous exploration of the data. Supplementing this, is the theory of a diverse economy. This will provide an alternative lens to the data, and thus will be presented in the discussion chapter. 


\section{Chapter Three: Results}

\section{Introduction}

In this chapter, results from the eight interviews (totalling ten participants) will be presented in five sections. Each section shadows the chronological order of questioning in the interviews (see Appendix 8). Section one shows results from LRE1 and LRE2. The mass of data from LRE1 is unpacked by exploring responses from each industry. Section two reveals specific comments on the five novel biotechnologies presented to participants. Section three shows the overarching themes that appeared during interviews. Section four, addresses a specific 'scenario question' in which a hypothetical release of gene drive is discussed with participants. The scenario featured at the end of each interview, thus a more complete position on biotech is rendered in participant responses. In Section five, aspects of a diverse economy are revealed among participants, displayed in a table. A diverse economy framework shows a relationship to tikanga and Māori business values, encouraging further discussion.

\section{Section One: Likert Ranking Exercises}

As detailed in the methodology chapter, Likert ranking exercises were used to show a snapshot of participant views on pests and ways to control them. In this section, the results from LRE1 and LRE2 will be set forth.

\section{LRE1 Results}

LRE1 featured seven fixed stems: wasps, stoats, possums, rats, cats, rabbits, and the great white butterfly. In addition, participants were able to propose pests that had not been listed in set stem categories. These are defined as Option A and Option B. Allowing participants to add pests of concern to their business that are not listed in the set stems, made for a convenient way to collect data on a topic that might otherwise be missed. Some participants named several optional pests on a single stem, which I did not find conflicting with the exercise. Optional stems were already a modification of a standard Likert. Thus, participants were not restrained from doing so. 
A total of 17 pests ${ }^{12}$ outside of the set categories were identified, these are (as written by participants with clarification by myself made in square brackets):

- Apple moth [same as codling moth although could be confused with painted apple moth]

- Argentine ant

- Ants [assumed ${ }^{13}$ to be Argentine ant]

- Bronze beetle

- Brown beetle

- Codling moth [apple moth]

- Grass grub

- Deer [there are several wild deer species, none were specified]

- King salmon

- Mealy bug

- Leaf curling midge [apple leaf curling midge]

- Leaf roller caterpillar [metamorphosis into light brown apple moth]

- Light brown apple moth

- Pigs

- Phylloxera [aphid]

- Wax moth

- Woolly apple aphid

As mentioned, participants were able to rank their nominated stems (Option A; Option B) alongside the set stems (PF2050 identified pests). Because Option $A$ and $B$ represent different pests among the participants, no clear delineation can be made from calculations like standard deviation ${ }^{14}$. The number of extra pests identified is likely to be partly due to the different industries involved, each subject to individual threats in yielding its product. Not all participants identified additional threats in items Option A and Option B. One participant left Option B blank. Instead of using it to identify a pest, it was strategically used to act as a buffer to the set items of which there were stronger feelings. For example, both optional categories were positioned at -2 and -3 , allowing them to make a stronger statement about the pest they were least concerned with, rabbits, which were logged at -4 .

\footnotetext{
12 Images of the optional pests identified are presented on the following page. Some participants identified the same pest by different names. These have been noted and condensed into a single image. Full image citations appear in the bibliography.

13 Elaborated on in the following subsection Apiculture.

${ }^{14}$ The raw LRE1 and LRE2 data can be viewed in Appendix 7.
} 


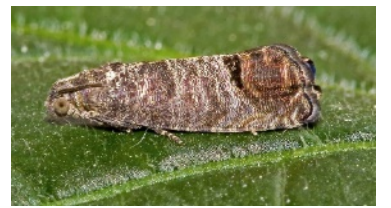

Figure 2. Codling moth (Cydia pomonella) - participant identified as apple moth (the colloquial name). (Wiki Commons n.d.)

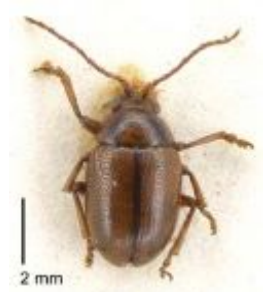

Figure 5. Bronze beetle (Costelytra zealandica). (Landcare Research n.d.a)

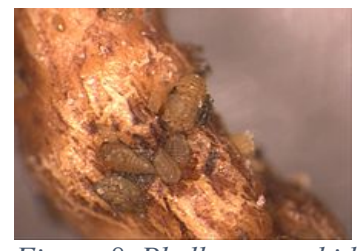

Figure 8. Phylloxera aphid (Daktulosphaira vitifoliae) "On vine image". (Schmid 2008)

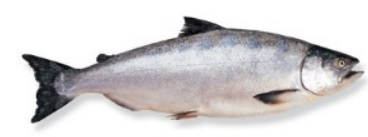

Figure 11. King salmon (Oncorhynchus tshawytscha). (Seafood New Zealand n.d.)

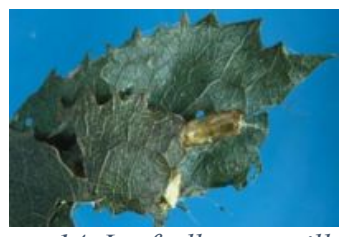

Figure 14. Leafroller catepillar (Epiphyas postvittana Walker) metamorphosis into light brown apple moth. (Landcare Research n.d.-d)

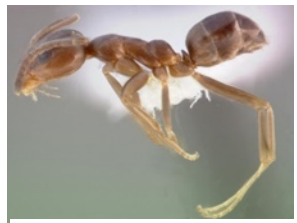

Figure 3. Argintine ant (Linepithema humile). (Landcare Research 2019)

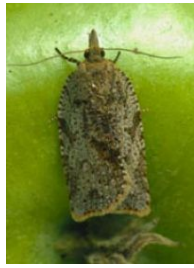

Figure 6. Light brown apple moth (Epiphyas postvittana Walker) metamorphosis from leafroller caterpillar. (Landcare Research n.d.-b)

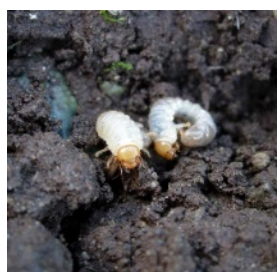

Figure 9. Grass-grub (Costelytra zealandica) - the larvae that forms codling moth. (Ag Pest n.d.)

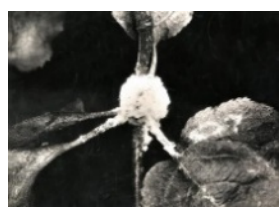

Figure 12. Woolly apple aphid (Eriosoma lanigerum). (Popay 2008)

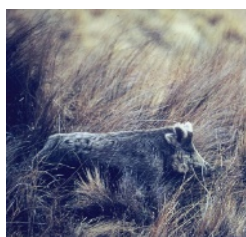

Figure 15. Wild boar - domestic pig (Sus scrofa). (DOC 2014)

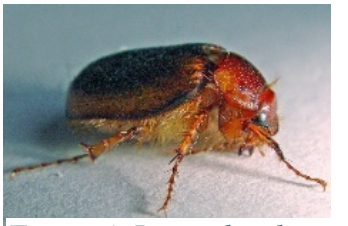

Figure 4. Brown beetle (Costelytra zealandica). (Bendal n.d.)

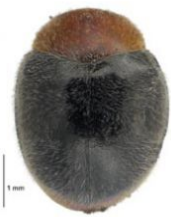

Figure 7. Mealybug lady bird (Cryptolaemus montrouzieri Mulsant). (Landcare Research n.d.-c)

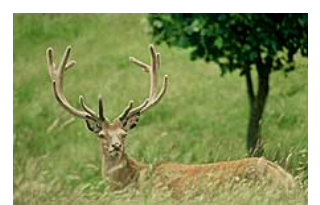

Figure 10. Red deer (Cervus elaphus scoticus) - participant did not specify which breed of deer affected them. (DOC n.d.)

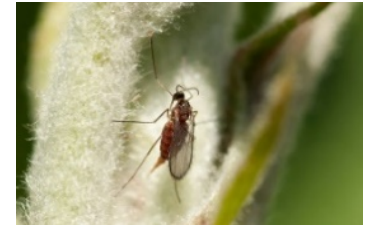

Figure 13. Apple leaf curling midge (Dasineura mali). (Plant and Food Research New Zealand 2013)

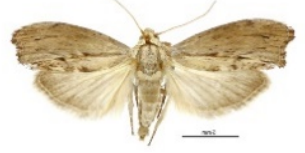

Figure 16. Greater wax moth (Galleria Mellonella). (Landcare Research n.d.-e) 
Six of the nine completed LRE1 ranked a nominated pest (Option A or Option B) as +3 or +4 on the response continuum, highlighting concerns that might otherwise have been missed without this exercise. Furthermore, only two of the optional pests identified are currently on the PF2050 hit list: Argentine ants, and deer (Department of Conservation n.d.). Thus, in the following sections, optional pests identified in LRE1 will be explored across each industry.

\section{Apiculture}

In the optional categories Apiculture identified the following pests outside of the set categories: Argentine ant, ants, wax moth, and king salmon.

Among the apicultural subset, only two participants agreed on the most concerning pest. Pūkeko and Mohua ranked stoats as their most concerning pest, +4 , on the response continuum. The remaining three apiculture participants identified alternative pests as most concerning: wax moth, Argentine ants, and king salmon. This is significant in that only two of these pests, the Argentine ant and wax moth, have a direct impact on honey production; while king salmon and stoats have little to do with apiculture. Wasps, which based on the literature review, had been assumed to be the priority pest for these businesses, however, they were positioned as the second most concerning pest +3 by only three of the five participants in this sector. The remaining two participants positioned wasps as +1 .

One participant, located in Te Tai Tokerau (Northland) identified Argentine ants as "a massive problem". It was speculated that the sandy soil composition may give reason for their persistence and abundance in the region. According to the participant, Argentine ants steal the honey, are hard to kill, and often result in the abandonment of hives: "...to limit or reduce the risk of spreading the ants we just leave the bees there" (Kererū). Another participant from the same region and in very close proximity to the participant described above, also talked about ants without specifying which species, however, it can be assumed that they were also referring to Argentine ants. This participant ranked wax moth Galleria mellonella (also known as the Greater wax moth) as their most concerning pest, positive four +4 . Although the participant did not 
go into detail about the effects wax moth had on their production, it was clear that they were a nuisance, and a priority. The wax moth has a predisposition to attack hives in the participants' storage unit. The current pest management strategies employed to deal with wax moth were baiting with poison, and freezing infected equipment to kill the larvae.

A surprising result from the ranking exercise is the participant that ranked king salmon as the most concerning pest to their business. The salmon was described as being detrimental to the waterways and "life force" (mauri), indicating the importance of tikanga in their decision making. A concern raised was that the salmon excrement which was, "...like tar", sitting on the bedrock of rivers, detrimental to river ecology. An intersection with their core values was evident in how salmon farming was described.

Commercial farming in any form, even bees, is detrimental to our environment if it's not monitored... to increase and boost those volumes, you then have to work outside of nature's own ways, which then has an impact on the environment. (Tūî)

Mohua went on to say "...they pump them [salmon] full of antibiotics. So again that's not natural". From these statements, the importance of 'natural' production, where no chemical or biomedical intervention is made in the farming of food, can be seen as a key value to the business. Additionally, the type of production method, for example commercial farming, is problematic due to the increased pressures it exerts on the environment.

Mohua and Pūkeko ranked stoats as the most concerning pest. Mohua said that their organisation wanted the "ngāhere [forest] to be what it was", e.g. returning to the state of health before predators invaded. Based within an iwi organisation, the business works closely with the DOC to deliver pest management strategies in their rohe. They operate on a values-based system where four pou (pillars) of thinking are used to evaluate any action. Building on the response from the Likert scale with follow up questioning showed concern to matters that directly impacted their honey production were equal to environmental concerns. 


\section{Horticulture}

The horticulture participant listed the following as their additional concerning pests: brown beetle, leaf roller caterpillar, coding moth, woolly apple aphid, and leaf curling midge.

Although there was only a single horticulture participant, they listed more than one pest on the Option A and Option B categories. Some of their concerns were similar to that of viticulture - unsurprisingly as they both grow fruit. The optional pests identified were ones mentioned by the orchard manager to the person who was interviewed. The interviewee did not work in the orchards and was instead based in another division of the business; therefore, they could not elaborate in-depth about how these pests affect production.

\section{Viticulture}

Viticulture seemed to battle with more pests outside of the set stems than other industries. This is likely due to the need for undisturbed and optimised fruit growth to produce high quality vintages. The following additional pests were identified between two participants in different regions: mealy bug, apple moth, light brown apple moth, aphid Phylloxera, leaf roller caterpillar, bronze beetle, and grass-grub.

The hazards to grape growth that these pests cause are various. Moths lay eggs that hatch into caterpillars that eat the fruit. Phylloxera is a commonplace infestation on vine roots that occurred globally in the $19^{\text {th }}$ century, combatted by grafting new American vines to 'old world' vines (Goode and Harrop 2011).

A key point of difference between the two viticulture participants was the divided opinion on wasps. Mātātā depended on wasps in their production methods; Kākā thought of wasps as more of a pest. Kākā said, "a wasp will induce an infection, and that's a problem, particularly in Central Otago, and the closer you get to the forested areas". Mātātā's position on wasps will be discussed later in the 'value of a pest' subsection. Both Kākā and Mātātā were unified over the issues rabbits pose to vineyards. Rabbits have been known to 
eat irrigation systems according to Mātātā. Kākā commented, "I've seen vineyards devastated by rabbits".

\section{Agriculture}

There was only one agriculture participant. They identified pigs and deer in their optional stems. Pigs and deer did not affect the production directly, instead, they disrupted the native tree planting scheme that the business has invested in. It is interesting to note this concern, as it is classified as a nonmarket activity.

\section{Evaluating LRE1}

Initially LRE1 was designed as an exercise for participants to generate thoughts on what pests are concerning to their business. However in some cases the participants immediately moved beyond the direct impacts to their businesses. Thus, views on pests expressed in this exercise are not confined to the businesses but also extend to the values participants hold. Results from LRE1 can be understood in relation to Māori worldviews, in which environmental wellbeing, encapsulated in tikanga like mauri and kaitiakitanga hold precedence. The pests identified are the most concerning pests at all times to the participants - not just when they are managing their production. In the case of king salmon, its high ranking over pests that have a more direct effect to honey production demonstrates a holistic concern.

\section{LRE2 Results}

LRE2 had nine set stems to be ranked on the response continuum. There were no optional stems in this exercise. Participants were asked to rank pest management techniques in order of preference. As mentioned, these categories are: do nothing, manual extraction, species specific poison, nonspecies specific poison, Trojan mite, RNAi, gene drive, Trojan female, and pheromone lure.

Although quantitative figures can be derived from the ranking exercises, as mentioned, these are only indicative and hold little meaning. Nonetheless, I will 
briefly indicate these results here, which will be illuminated by the qualitative responses of participants in the following sections.

The pheromone lure had a standard deviation of 1.5 , the greatest level of consensus. Tailing this was 'do nothing' with a standard deviation of 1.73. Contrastingly, the non-species specific poison had the lowest level of consensus with a standard deviation of 3.19. A surface analysis of the ranking exercise results suggests a sporadic approach may have been taken by some participants. Explained in the methodologies chapter, at times, people found it difficult to rank items in order of preference, sometimes wanting to place multiple items on one degree of the continuum. LRE2 proved to be more difficult for participants than LRE1.

Limitations of both ranking exercises should be acknowledged, the most obvious being the small sample of participants. Furthermore, given that the exercise took place at the beginning of the interview, it mostly reveals a 'first stab' at what biotechnologies might be acceptable. This is compounded by the fact that several participants did not read the primer document, highlighted by a participants comment during the exercise: "this is the first time that I've heard this language". These views instead become more crystallised in the "scenario question", discussed later in this chapter. Due to these factors and the constraints of space in this thesis, it seems more appropriate to focus on the themes that emerged during interviews as opposed to an in depth analysis of LRE2.

\section{VESPEX®}

Discussion on Vespex® was prompted by LRE2. Apiculture participants make up a large proportion of interviewees in this thesis: four businesses with six participants. I was eager to hear participants thoughts on Vespex® to see if it was effective or not, and if it influenced interest in biotechnologies. Already mentioned, is the stem in LRE2 which includes a 'species-specific poison' with the example of Vespex®. Vespex $®$ has been shown to be extremely effective in eradicating German and Common wasps (Edwards et al. 2017). In a personal communication with a Vespex® distributer, they confirmed that Vespex® only 
targets social wasps (i.e., German and Common wasps), whereas native wasps are not social wasps, thus unaffected.

Two apiculture businesses had used Vespex®; while the other two had not but were interested in it or had intentions to try it in the future. The 'speciesspecific poison' stem, which Vespex® is an example of, was highly regarded by all apiculture participants in LRE2, ranked as +3 and +4 on the response continuum. However, Pūkeko found Vespex® to be ineffective saying that "it's not enough and it's quite labour intensive. Visually, not so attractive". Pūkeko's concern of how Vespex® looked was due to his tourism business that utilised the land where Vespex® was used. This view is worth noting, as it is contrasting to the evidence of its success (Carson 2018; Edwards et al. 2017).

The other apiculture business with experience were "quite happy with it", although they were yet to discuss its effectiveness with other beekeepers. Toutouwai and Kākāpō said, "we had other methods, but it was a real problem this season with the wasps. So I just thought we needed to try". They had previously been baiting with sardines to poison wasps with 'spot-on', a flea treatment that "sort of worked". However, spot-on had recently become more expensive, potentially motivating their use of Vespex®.

\section{Section Two: Interrogation of the biotechnologies}

Although not all participants addressed each and every biotechnology presented in LRE2 or the primer document, some did share in-depth thoughts on a case by case basis, presented in the following subsections.

\section{Trojan Technologies}

Trojan Female and Trojan Mite featured as two separate biotechnologies in LRE2. However, the Trojan female option was seldom talked to. This could be because the Trojan mite represented a more familiar or tangible scenario e.g. a disease being released to affect something. Only Kākā spoke to the Trojan female, describing it as a less targeted method, thus a risk: 
You would have to be extremely sure that whatever genetic manipulation that had gone on within that Trojan was not going to affect anything off target. (Kākā)

By contrast, the Trojan mite was prominent in discussion. Several participants expressed concern at the release of a Trojan mite, making it the least accepted biotechnology among participants.

Four different interviews, containing a total of six participants, signalled discomfort and doubt about the Trojan mite. Concerns ranged from mutations in the released pest, to unintended effects on other species and unknown side effects to ecosystems - the subject of a theme to be discussed later in this chapter.

Mātātā expressed several concerns regarding Trojan mites based on previous experience introducing predatory mites to control pest mites that infested blackcurrant crops. One issue with this was deploying the predatory mites at the correct time, as their life cycle needed to be accounted for. Additionally, it was "hard to gauge whether they work or not", suggesting it was an unreliable option for future pest management techniques. Mātātā's description of the Trojan mite was likened to a bio-control as opposed to the disease-carrying mite that was described in the primer given to participants.

\section{Gene Drive}

Mātātā initially showed interest in the use of gene drive, although admitted that they had not heard of the technique beforehand. The application of gene drive on the apple moth was of particular interest, however, Mātātā did comment:

I guess on the other hand, I don't really know why the Apple moth exists for any other reason, what part it has in the life cycle of other insects. (Mātātā)

Mātātā's remarks show careful consideration of the ecosystem and relate to the statements made by Weka, who expressed concern of the flow-on effects that eradicating a species may have to cultural identity. Weka discussed this hypothetically by posing that one insect's eradication could lead to another pest flourishing. Weka drew attention to the potential impact of a new pest, 
which could feed on kawakawa, a native plant central to tikanga and mātauranga. Thus, impacting on Māori ability to uphold tikanga practices and practice rongoā (traditional medicine). The scenario presents an insight to the potential reasons as to why some Māori might be opposed to biotechnologies. Kererū had a preference for fast kills of pests and so gene drive was less attractive, however, they did state that it could be of interest as technology improves.

\section{RNAi}

Few participants commented in depth on RNAi. During interviews, this was generally the more confused biotechnology, whereas gene drive and pheromone lures were more comprehensible. Tūĩ did question wording of the primer which declared it as a relatively cheap technology: "RNA is purported to be relatively cheap, and I put, is that the driver?" implying a 'cutting corners' attitude by science. As mentioned in the methodology chapter, the primer document was produced by a colleague and then repurposed by myself for this study, however, the remarks on cost effectiveness is supported in an article by Sun and Rigs (2017).

Kākā found RNAi and gene drive to be "clever" science. They found these biotechnologies equally interesting, but RNAi seemed more specific.

\section{Pheromone Lure}

Participants were relatively unified on the use of pheromone lures, having the highest consensus in LRE2. This is likely to be connected to the familiarity participants have with the concept. Five participants spoke of experience with pheromone techniques or familiarity with its usage in related industries. For example, Mātātā had used pheromones in the past when working with berries, and currently used them to trap moths. Another participant identified similarities with the lure concept and their current after-market approach to trapping wasps by attracting wasps to poison laced sardines. 


\section{The Value of a Pest}

"But wasps are good for us" (Mātātā)

A valuable contribution to the discourse on pest management and biotechnologies that has arisen from this study are the nuances on what value a pest may have. To some, a pest may be just that, something that needs to be controlled or even eradicated; to others it can be extremely valuable to their production methods and perhaps even vital. One interview stood out in regard to this discussion. Mātātā, representing half of the viticulture cohort described a positive value in wasps, illuminating points made in the literature (Lester 2018; New Zealand Wine n.d.; Sowman 2017). Wasp presence in the vineyard provides vital pest management that is currently unmatched:

They are actually quite beneficial to eating pests. I think they do actually eat the light brown apple moth. There's other bugs, like the mealy bugs...lady birds are good as well...they eat things like aphids and mites, and bits and pieces like that. The lady birds and wasps are the best things you can have. (Mātātā)

Further understanding of the value wasps have to the vineyard can be ascertained by considering the reduction in insecticides during the production process. In turn, this has the potential to create value-add ${ }^{15}$ to the final product if it were to be incorporated into their brand strategy or endorsed through the likes of organic certification.

Mātātā's comments contrasted to those of Kākā, the other viticulture participant in the study. Kākā ranked wasps as +1 in the LRE1, stating that it was his fourth most concerning pest to the vineyard. Additionally, Kākā uses manual extraction in what they term "wasp hunts" every spring and autumn. Kākā, who holds a master's degree in organic viticulture, elaborated on their concerns:

The German wasps are a problem because they are unlike bees, so they will injure fruit... [bees] they're like a rubbish man, you know, if fruit's damaged, a bee will get in and it's obviously attracted by the sugar and some of the aromatic and flavour compounds within the fruit, and they actually clean it out, and they

\footnotetext{
${ }^{15}$ An extra benefit or enhancement to a product.
} 
prevent secondary infection. However, a wasp will -- it will induce an infection, and that's a problem. (Kākā)

Kākā's concern's lay with the German and Common wasps, unlike the native wasps which they said are "really useful".

The contrasting differences between the two viticulture industry participants shows a nuanced approach to how wasps are accounted for in pest management. Furthermore, the location of both viticulture participants was in Te Waipounamu, poses interest. Mātātā is located in North Canterbury; while Kākā is located in Central Otago, and as previously mentioned he worked at vineyards close to lakes in the region where wasps are more prominent. This will be discussed further in the following chapter.

\section{Section Three: General themes}

\section{In Favour}

Participants that expressed acceptance towards biotechnologies did so in varying degrees, and in some cases, placed certain limitations on how far the technology might be applied.

Pūkeko had discussed the biotechnologies among his colleagues, coming to the conclusion that they were acceptable. Their basis was that current pest management challenges were modern phenomena:

...we're dealing with an issue that essentially, post-dates many of the essential elements of the kaupapa we work with. Like the introduction of some of the pests are things that our old people, wouldn't necessarily had the tools to deal with. They wouldn't have necessarily had the issues to deal with anyway. The pests weren't there. We can't see any conflict with the adoption of new approaches to control. (Pūkeko)

They went on to describe the potential risk of a pest to industry as being an influential factor in adopting such technologies. And that "...there is likely to be more tolerance of a pest modification/technique, than there is to a food modification/technique".

Other participants, Kākāpō and Toutouwai, expressed an interest in the technologies, and commended the research being undertaken on biotechnologies. 
Tūī who held the strongest anti-biotechnology position felt that the majority of industry would be in favour of using biotechnologies. Weka said that adopting biotechnologies in the worst case scenario, where the future of production is threatened, would be a "no brainer".

Well, at the moment we currently use sprays to kill all of these things. And that's what pretty much every agricultural industry across the world does. So, if you're taking out sprays and introducing something that within particular areas wipes out a particular pest, I'd be surprised if there was overall backlash. (Weka)

Pūkeko had no problem looking to new solutions for problems but made space for considerations saying:

I don't think that there is any compromise in the adoption of new tools. Provided, if you are getting into ethical issues, we would need to think case by case about that issue. (Pūkeko)

Kākā indicated a strong interest in the RNAi and gene drive but said they would like to know more. "I don't know enough about them, but RNA interference or gene drive seem to me, to be clever. That's where we probably should go".

\section{The Need to be Specific and Targeted}

Kākā accepted the use of biotechnology on the condition that it was certain only the target species (German and common wasps) would be affected. An emphasis was made that the use of biotech should not extend to the native wasp populations. "If it's specific to those particular species, and there was no chance of inadvertent spread into the native population, then you'd have my full support". Furthermore:

I don't have an issue with manipulating genes within a species, but certainly interspecific, no deal. Can't do it, you know? That's just not on. (Kākā)

Kārearea shared the same view saying, "I quite like targeted things, so for me, I'd put the more targeted options over here".

The idea of a targeted method ties in to the related theme of preventing any side effects to nature or ecosystems. Toutouwai stated, "As long as there was no crossover with any of our other insects". This statement reverberates with previous research identified in the literature review that showed issues in the mixing of whakapapa in genetic research. 


\section{Side Effects}

As hinted in the LRE2 results, several participants brought up the potential for side effects to occur in the release of a biotechnology.

When mentioning the need for a targeted approach in the use of biotechnologies, Kākāalso touched on the notion of 'side effects', emphasising the importance of there being "...no chance of inadvertent spread into the native population", and to ensure that a biotech was "...not going to affect anything off target". Kākā also spoke frankly about public perceptions, stating:

The notion of a - you know - a Franken bug - getting out there, is - I mean, that scares the willies out of everyone. (Kākā)

Tūĩ also theorised the possibility of a mutation over time, they put forward the idea of a super wasp evolving a type of resistance to biotechnologies. Additionally, they raised the possibility of asexual reproducing species in the event of the eradication of one of the sexes.

Other participants were not so explicit with any potential side effect, they at times hinted feelings of concern that relate to the potential for repercussions.

My concern with these ones here, about the DNA and stuff like that, is, what if whatever is done sort of mutates into something else? You know, the unintended side effects. And then it becomes a new problem. (Kārearea)

Often connected to the concerns of side effects was the introduction of a Trojan mite, which was received negatively.

A Trojan mite for example, introducing a disease carrying mite, you know what's to say that disease might not mutate into something else that we can't control? (Kārearea)

Toutouwai also disliked the mite: "I don't like the idea of introducing mite. You know, what happens with it if it tacks onto something else like a bee?".

Kākāpō who was in the same interview as Toutouwai, was equally opposed saying, that the Trojan mite "...might start bloody breeding with Varroa mite"16. Overall the Trojan mite option generated the most reluctance to adopt.

\footnotetext{
${ }^{16}$ Varroa mite transmits a virus to honey bees and feeds on their food supplies; it does not effect wasps (Lester 2018).
} 


\section{Drawing On Past Experiences}

Some participants drew from previous pest management strategies to justify their position. Tưi and Mohua recounted the release of the calicivirus and deliberated that it was ineffective. Kārearea also recalled the release of calicivirus and made the point that rabbits are still a huge problem in the Mackenzie region. While Kākā said he was awaiting the results of the latest efforts to control rabbits, RHD mark II, making the point that:

... with any biocontrol strategy that's put in place, you know, the effectiveness is dependent on a whole lot of factors that may or may not be in the control of the people who released it. You know, there's a whole lot of unintended consequences in biocontrol systems, as you're probably well aware. (Kākā)

Elsewhere, Kererū expressed discomfort in 1080. They emphasised they did not know enough about 1080, and were not involved with any "groups". However, they did not support its use based on news coverage, and social media. Although not discussed in-depth, Kererū's position on 1080 poses questions when considering their positionality on biotechnologies - a point to be discussed later. Adding to this theme is Toutouwai and Kākāpō who spoke positively about their experience with 1080 , however, this has been added to the "consultation" subsection, as it surfaced during the final questions of the interview.

\section{Additional Information Required}

The majority of participants required more information before proceeding to make a concrete decision on biotech. This theme shows a need for accessible and concise information for the non-specialist.

Pūkeko touched on information clarity alongside validation of its use:

If the introduction was explained to us and explained well. All the potential impacts were well explained, and we believed the problem was a real problem, then we would be supportive of it. (Pūkeko)

Similarly, Kākā, suggested consent to biotechnology being used in pest management but more information was still required: "I'd need to know more about it, but I think that's probably one of the best ways to go". Comparable to 
the notion of consequences was Mohua, who pressed for a justification and assessment of risk:

So if you were to eradicate in full entirety, wasps, what does that mean? And it'd probably be good for the bees and for the - I don't know - I'd want to know what harm, what actual potential harm would something like this have. We don't have the answers today, but that's what I want to know. (Mohua)

Both Pūkeko and Mohua are alike in their concern of risk which has also been addressed in the theme of 'side effects'. The difference here being that side effects are linked to the need for more information before deciding on biotechnology's acceptability. This could be mitigated through further research that modelled any potential risk or hazards.

The clarity of communication was also a point made, eliciting the issues of science communication and information which may host complicated terminology.

...it doesn't have to be too detailed or too complicated, just needs to be a simple explanation of what the advantages are, and what the implications are - what the risks are. (Pūkeko)

Reiterated in another interview, Kākāpō said "it would have to be clear".

Information that is balanced would also be valued, as implied by Kārearea who said: "I'd want to see some good science behind it". Such a comment is worth contemplation, as it shows a point of acceptability is possible if it were "good science". To unpack this phrase further, the perceptions of science should be considered. What is the current relationship between science and nonspecialist peoples?

\section{Disapproving}

Positions against biotechnologies were also reasoned by the intersections with tikanga and Māori concepts.

DNA modification, gene slicing or whatever they call it, is around the whakapapa, the mauri, the life force that everything has. We are just worried about that. Because everything has a life force. Once you start playing with it, what does it mean? (Mohua) 
This is in direct opposition to the statements in favour of biotechnology by Pükeko who reasoned that the issues presented by the pests of today post-date tikanga. Kārearea queried traditional Māori views in relation to the use of biotechnologies in pest management:

I guess if you look back at Māori culture over history, that's never really come up. It's not something that was ever considered. It's only really in modern times that we've had to answer questions like this. I'm not sure to be honest. Probably wouldn't sit too well, I think. (Kārearea)

Kārearea's comments bring to mind Mead's (2003) thoughts on biotechnologies, in which Māori need to remain sharp in their tikanga to assess its appropriateness.

Tūī also opposed biotechnologies, advocating for natural ways to control pests in the future. They called attention to finding elements in nature that wasps dislike, and unlocking the potential of naturally occurring substances like kānuka (Kunzea ericoides). In this sense they were interested in bio-controls that came from plants rather than other insects or pests.

\section{Trust In Research}

Participants made comments on science, some reflecting trust; others reflecting distrust.

We have to take the advice that's available at the time, I guess. That's been the cause of some mistakes in the past. But I hope that the science and technology is getting better. (Pūkeko)

Toutouwai and Kākāpō valued their positive experience with 1080, which seemed to advance Kākāpō's position on biotechnologies. Kākāpō specified that any decision process would require "full research, and data, and everything, I guess" and collaboration. They valued research, saying, "pour the money into the research". Most of their comments stemmed from previous interactions with 1080 , in which they experienced a positive consultation and outcome. 


\section{Impact on Brand}

The impact biotechnologies might have to participants' businesses was not always clear, however, brand integrity did surface at points. Opinions ranged from uncertainty to negative impacts.

Kererū did not find any ramifications to business image or industry. While Pūkeko admitted, "I don't know what the ramification to the sector would be". Kārearea alluded to negative impacts, saying, "I don't think it would sit too well'. Mātātā signalled that the association of GE and biotechnologies would not necessarily benefit a brand, saying: "I don't think you'd be advertising it [biotechnology]".

\section{Tikanga Values}

Discussion on tikanga was prompted at points during interviews. Participants often brought up tikanga perspectives when considering their business values. Kererū said that whakawhanaungatanga helps to guide interaction with clients, and said that more consideration of tikanga was on the horizon for the business. Pūkeko cited kaitiakitanga, manaakitanga, whanaungatanga, kotahitanga (unity) and rangatiratanga (chieftainship, leadership) as the guiding Māori values to their business practice. This was exemplified in their kaitiakitanga strategy to not extract more than what is sustainable from a source, which they applied to their honey production. Mohua and Toutouwai integrated tikanga into their daily practice through karakia and the use of their four pou or lenses which are summarised as:

What's it doing to tikanga, to culture, the way we do things, our values? How's it going to impact our people? How does it impact the greater environment? And then what's the economic sense as well, in terms of all of those four things. Will what they're doing in this hypothetical approach do more good than harm? And how will we know that? (Mohua)

They compared karakia to health and safety risk management, in which they were protected in their actions. Actions of the business always aimed to look after the environment and build capacity among its iwi membership. This was evidenced in the skills they offer whānau, such as apiculture training. 
As identified in the themes 'in favour' and 'disapproving', aspects of tikanga also appeared in decision making.

\section{Section Four: Scenario Question}

Near the end of each interview, I posed a 'hypothetical scenario' in which gene drive had been approved by the New Zealand government for use on pest wasps in the year 2025. I asked participants how this would make them feel and if there would be any ramifications to their industry. This question gets to the crux of participants' views on gene drive, arguably the more extreme biotechnology presented to participants. Thus, the following themes represent the most complete views on biotechnology and respond directly to the key question: what are Māori business perceptions of biotechnologies in pest wasp management?

\section{Types of Acceptance}

Outright acceptance of the scenario question were not expressed. However, two types of acceptance were observed.

Firstly, Pūkeko said if it was "...aimed at reducing or eliminating the wasp issue, then that would be the end of it as far as we were concerned", however, this was on the condition that it was "explained to us and explained well".

While Mātātā showed a reluctant acceptance, saying, "it might hurt some people but in the end if it's for the greater good... then you have to have some trust in the government". This statement implies trust in authority and also alludes to their opinion not having influence in decision making.

\section{A Need to Know More}

The majority of participants said outright that they did not know enough to decide on the hypothetical situation at hand. There was a call among participants for clear communication from multiple sources before making any decision on biotech.

Mohua said they would require "...expert advice in front of us, which is from both sides of the argument, and either support it or not". Kārearea shared a 
similar view, wanting to see "good science behind it" and "some independence to verify what we're being told is going to deliver". Thus, a need for information that is impartial is emphasised. Participants phrasing also suggests that if these conditions are met, then reaching a concrete decision on biotech would be possible.

Kākā was somewhat permitting in his stance but this was conditional on further information, saying, "I'd need to know more...but I think that's probably one of the best ways to go".

Weka reiterated concern about potential side-effects that eradicating wasps might have to their business.

Unless you can tell me the flow-on implications from an environmental point of view of completely eradicating wasps, then it's really hard to answer that question. (Weka)

Weka also emphasised a need for clarity on industry specific impacts. Similarly, Mohua said "does it do more good than harm, and how do we know?". Suggesting any advancement of biotechnology would need sound modelling to back-up its release.

One response showed moral conflict when considering the situation:

I think it's a hard one because wasps are a real pest for us. So, you know, like I know we're saying we don't want to do this sort of stuff, but actually, with a wasp... (Toutouwai)

Their generally opposing position on gene drive conflicted with its potential use on wasps, where it might be acceptable. This response illustrates how wasps as a 'prototype' for discussion on gene drive present an excellent case study to test acceptability of biotechnologies. In the interview Kākāpō seemed more permissive questioning Toutouwai and myself with "but what are wasps good for?". Kākāpō's question also shows a concern for the function wasps, which most participants queried at some point during interviews - hinting at the theme of 'side effects' once again. 


\section{Disapproving}

Two participants drew upon disapproving positions when responding to the scenario question. Kererū did not think that moving forward with gene drive was the right thing to do when considering others, saying:

I think the public perception would not agree to that, or you know, we wouldn't think that that is probably the best solution, to go and start mucking around with genes and modifying these pests and animals to kill themselves. (Kererū)

Tūi felt that the decision had already been made and that it would go ahead without her consent, saying, "unless you come up with a solution that's going to fix it, they've already got the solution". Their position shows a lack of trust in organisations - reiterating the findings of Roberts and Fairweather (2004). Tūî also felt that industry would lean toward accepting gene drive, saying, "I'd say the industry would say yes".

\section{Consultation}

Following the scenario question, I asked participants what steps they expected before a release of this technology. This question gave participants the opportunity to consider the methods of consultation they might find appropriate if such a scenario were to play out.

Toutouwai and Kākāpō modelled their response on their past experience with 1080 consultation in their rohe. This involved hui on marae (tribal meeting grounds) and clear information.

If it wasn't for our tikanga and wasn't for our iwi and our hapū, I mean, we wouldn't have got that 1080 drop done ... so that's empowering tikanga to look after our ngāhere. (Kākāpō)

This comment shows the potential of collaboration in the consultation process. Here, Māori benefited in being valued and given 'right of way' to conduct the consultation in processes that were appropriate to tikanga. However, as argued by Mutu (2002; 2010) Māori have often been left behind by consultation processes in the RMA, suggesting a need to upgrade policy so that the government is held accountable to fair and genuine consultation processes. 
Pūkeko stressed the importance of iwi consultation saying that "we would be slightly miffed if we weren't consulted". Pükeko also stated that due to his involvement with iwi that there would be two positionalities at play: the business viewpoint, and the iwi. Mohua suggested "socialising" this conversation among the Iwi Chairs Forum, an established network of Māori leaders. Kererū suggested a need for public feedback.

Tūĩ explained her thought process in decision making as "what does that mean for me and my whānau, and on my whenua. How does that affect me?". Tūî also so touched on the Treaty, saying, "you have to consult. You are touching nature. You are touching our whenua. You are actually influencing our wellbeing, and our wholeness".

\section{Section Five: A Diverse Economy Framework}

This thesis also sought to query if Māori business are involved in a diverse economy, as theorised by Gibson-Graham (2006). In the literature review it was shown that Māori academics are exploring the diverse economy theory in Māori businesses to better understand practices and motivations. Linking to this research is an opportunity to continue this prospect while researching with a niche sector of Māori businesses. The results from interviews show an unprecedented involvement in non-market and alternative market activities, disrupting capitalism. To make sense of this data, the information has been processed and displayed in table 1. With a focus on transactions, the vertical axis of the table shows diverse economy components: market, non-market, and alternative market. Examples from businesses are given along the horizontal axis of each category. I have then filtered these examples into the row 'connection to Māori values' in which I find links between the diverse economy examples and Māori views. From the table presented here, many questions and points of inquiry arise, which will be examined in the following chapter.

An engrossing finding is that all businesses interviewed in this thesis are involved with aspects of the diverse economies framework, most notably non- 
market activity. Businesses' involvement ranged from environmental to community investments. Virtually none had a monetary return on investment. The closest exception being an iwi project that encouraged its tribal members to make profit for themselves if they wished. Even so, the investment is passed on in new skills rather than being absorbed back into their business. In addition, there is no clear example, as to how sponsorship might sit within a diverse economy framework. However, in the examples from Gibson-Graham (2006) and Bargh (2011), scholarships funded by businesses are categorised as alternative capitalist. In another example, the act of "corporate gifts to trading partners, to communities" is described as a non-market activity (GibsonGraham 2006:75). This creates ambiguity as to how to categorise sponsorship, as there is an element in gifting i.e., new uniforms for a local sports team, or transport being paid for tournaments. Although advertising can be leveraged in some instances, it would typically only be when sponsoring professional sports teams. Thus, a participant's sponsorship of a "local sports team" in a rural area suggests little to no return in advertisement. Deliberating this, sponsorship has been allocated as alternative market in Table 1. Nonetheless, it should be duly noted that there may be unknown nuances to the categorisation of alternative market in this table.

Examining Table 1 (pg. 78), business activities are charted in a diverse economy, exposing new ways of thinking in regard to how Māori business values are dispersed. Evident in the table, is how this cohort of Māori businesses devote an aspect of revenue to activities that benefit and uplift community via nonmarket and alternative market activities. These activities have links to tikanga Māori values that I have associated in the final row of Table 1 "connection to Māori values".

Gibson-Graham's (2006) notion of "Indigenous exchange" can be re-configured to Indigenous concepts, with the benefit of producing more relevance to Mãori. For example, it is clear from Table 1 that kaitiakitanga is an ethical consideration for many of the businesses in this study. One participat 
Table 1. Participation in a diverse economy framework

\begin{tabular}{|c|c|c|c|c|c|c|c|c|}
\hline & Weka & Mātātā & Kākā & Pūkeko & $\begin{array}{l}\text { Mohua } \\
\text { Tūī }\end{array}$ & $\begin{array}{l}\text { Kākāpō } \\
\text { Toutouwai }\end{array}$ & Kererū & Kārearea \\
\hline $\begin{array}{l}\text { Market } \\
\text { activity }\end{array}$ & Grows fruit. & Makes wine & Makes wine & Harvests honey. & Harvests honey. & Harvests honey. & $\begin{array}{l}\text { Harvests } \\
\text { honey. }\end{array}$ & $\begin{array}{l}\text { Produces } \\
\text { milk. }\end{array}$ \\
\hline $\begin{array}{l}\text { Non- } \\
\text { market } \\
\text { activity }\end{array}$ & $\begin{array}{l}\text { Riparian } \\
\text { planting. }\end{array}$ & $\begin{array}{l}\text { Planting } \\
\text { scheme in the } \\
\text { vineyard and } \\
\text { region. }\end{array}$ & $\begin{array}{l}\text { Donations to } \\
\text { health } \\
\text { organisations } \\
\text { and native } \\
\text { bird } \\
\text { conservation. }\end{array}$ & $\begin{array}{l}\text { Outreach } \\
\text { educational } \\
\text { activities with } \\
\text { children. }\end{array}$ & $\begin{array}{l}\text { Upskilling iwi } \\
\text { members with } \\
\text { apiculture } \\
\text { knowledge. }\end{array}$ & $\begin{array}{l}\text { Having influence } \\
\text { in DOC and iwi } \\
\text { lands through } \\
\text { relationships to } \\
\text { sustain } \\
\text { honeydew } \\
\text { supplies. }\end{array}$ & $\begin{array}{l}\text { Outreach } \\
\text { educational } \\
\text { activities } \\
\text { (relating to } \\
\text { the } \\
\text { environment) } \\
\text { with youth. }\end{array}$ & $\begin{array}{l}\text { Native } \\
\text { planting } \\
\text { scheme. }\end{array}$ \\
\hline $\begin{array}{l}\text { Alternative } \\
\text { market } \\
\text { activity }\end{array}$ & $\begin{array}{l}\text { Operates as } \\
\text { an iwi } \\
\text { business. }\end{array}$ & & $\begin{array}{l}\text { Operates as a } \\
\text { whānau } \\
\text { business. }\end{array}$ & $\begin{array}{l}\text { Operates as a } \\
\text { whānau business. }\end{array}$ & $\begin{array}{l}\text { Operates as an } \\
\text { iwi business. } \\
\text { Whānau have the } \\
\text { option to be } \\
\text { profitable for } \\
\text { themselves. }\end{array}$ & $\begin{array}{l}\text { Operates as } \\
\text { whānau } \\
\text { business. } \\
\text { Sponsors local } \\
\text { sports teams. }\end{array}$ & $\begin{array}{l}\text { Sponsors local } \\
\text { sports teams. }\end{array}$ & $\begin{array}{l}\text { Operates as } \\
\text { an iwi } \\
\text { business. }\end{array}$ \\
\hline $\begin{array}{l}\text { Connection } \\
\text { to Māori } \\
\text { values }\end{array}$ & Kaitiakitanga & Kaitiakitanga & $\begin{array}{l}\text { Koha } \\
\text { Hauora } \\
\text { (wellbeing) } \\
\text { Kaitiakitanga }\end{array}$ & $\begin{array}{l}\text { Whanaungatanga } \\
\text { Whakapapa } \\
\text { Mātauranga }\end{array}$ & $\begin{array}{l}\text { Tino- } \\
\text { rangatiratanga } \\
\text { Mātauranga }\end{array}$ & $\begin{array}{l}\text { Mana Whenua } \\
\text { (territorial } \\
\text { rights) } \\
\text { Manaakitanga } \\
\text { (hospitality) } \\
\text { Kaitiakitanga }\end{array}$ & $\begin{array}{l}\text { Manaakitanga } \\
\text { Mātauranga } \\
\text { Kaitiakitanga }\end{array}$ & $\begin{array}{l}\text { Kaitiakitanga } \\
\text { Whakapapa }\end{array}$ \\
\hline
\end{tabular}


describes this outright as being a way to give back to the whenua from which they profit, evoking the inherent responsibilities of kaitiakitanga, but also an "Indigenous exchange" or utu (compensation) with Papatūānuku (Mother Earth) (Bargh 2011).

We're putting in a monetary investment, but there's no monetary return on it. There's zero. It's all about cultural and putting back in to the land. Because we're using the land to make a gain from it, so it's our opportunity to put something back into it. (Kārearea)

Kārearea and Mātātā are both involved with planting schemes on their work sites. Kererū said that they were currently looking to work with a local school to administer a planting scheme. All three participants are invested in modes of kaitiakitanga - looking after the land and sustaining it for future generations. These activities have no direct value-add to their product. Their environmental strategies are not marketed to the consumer as a reason to buy their product and feel good. Instead, their values towards the environment are inherent, holding a non-monetary place in the business. Of course there is potential to monetise such activities, however, the businesses did not allude to this being developed.

Mohua spoke about the need for independence from market forces. This could be achieved by encouraging whānau to resource themselves with new skills and valuable commodities.

If we engage our own whanau to self-sustainability, they'll grow their own tomatoes. They may start off with genetically modified tomatoes or whatever, but then they may actually be able to, because they're feeding themselves and sustaining themselves, they don't have to mass produce. (Mohua)

Their initiatives extend beyond bee keeping, however, the ethos remains much the same - to increase self-sustainability, a marker of tino rangatiratanga.

Kererū, Pūkeko, Kākāpō, and Toutouwai all contributed to one or more forms of community engagement like educational activities and sponsorship of local sports teams. Kererū said that "educating kids around the importance of the environment, the importance of bee keeping, and the importance of working hard" were key values the business held - evoking kaitiakitanga and 
mātauranga. Investment in these outreach activities have no direct returns to their businesses, however, they do contribute to core values which may enhance their ability to produce their primary products.

\section{Conclusion}

Participant's thoughts and reasoning regarding biotechnologies generated a wide range of discourse that intersected with several key areas of concern. Roughly three "camps" of opinions surfaced: accepting, a need for more information before reaching a decision, and disapproving. From this, the largest portion of participants were concerned about getting clear information on biotechnologies, should they be considered for release. Expanding on this was the issue of specificity in any application of a biotechnology. The desire for a targeted and controlled method that would not interfere with other species was echoed. Connected to this theme was the issue of side effects to ecosystems, products, and business brands.

A small number of participants questioned biotechnology in relation to tikanga. Of those participants, polar ends of the spectrum were represented: those who saw no conflict; and those who saw an immense clash of values. Where the issue sat within tikanga values was at times unclear, however two participants noted that biotechnologies post-date traditional tikanga issues, thus implying that tikanga is fluid and adapting to "modern" methods. Others felt that biotechnology was a disruption of nature and therefore not tika (correct).

Both Likert ranking exercises proved to be useful in generating conversation on the central issues this study investigates. Participants supplied several points of supplementary information in LRE1. Additional pests were named by participants, some of which were more concerning to businesses than those identified by PF2050. These exercises also illuminated the levels of concern towards wasps, which look to be medium to low priority when compared to other pests identified. Connected to this was the surprising finding that one participant benefits from wasps - contrasting to some impressions in the literature. 
Diverse economies were also reported in non-market and alternative market activities, all of which show links to Māori values. All participants gave examples of diverse economic activity, which is an intriguing finding to be explored in the discussion chapter. 


\section{Chapter Four: Discussion}

\section{Introduction}

The results chapter showed several points of interests and places of inquiry going forward. In this chapter, the implications of select key findings in this thesis will be discussed across three sections. The first will expand on how industries in this thesis might contest the portrayal of wasps, resulting in a need to re-imagine impact calculations. In section two, the diverse economy framework helps to construct two tables, showing that non-market interests play a role in decision making. Lastly, the recurring call for more information by participants is weighed against current communication strategies. Considerations are then made as to how to proceed with biotechnologies.

\section{Section One}

\section{Wasps: Friend or Foe?}

Highlighted in the results was a single participant who found wasps to be beneficial to his business. Representing one-half of the viticulture participants, they found wasps useful as they acted as a bio-control, eating bugs like aphids that would otherwise be problematic to their business. The benefits they saw for wasps extended to a reduced reliance on insecticides, creating healthier soil. The participant appears to be an outlier in the study, as they are the only business to explicitly state they like wasps. The closest position to this were participants who questioned what role wasps play in the ecosystem. How is it that the two viticulture participants are starkly contrasting?

Looking back to Maclntyre and Hellstrom (2015), no connection is made to the potential benefit wasps may have to businesses; alternatively, a focus on the detrimental costs to industries is depicted. Almost ironically, after making contact with select vineyards and industry experts, they determine wasps have little-to-no financial impact on viticulture and therefore are excluded from further investigation (ibid.). Their consultations extended to Malborough, Wairarapa and Otago (ibid.). Hence, it is surprising that two viticulture 
participants in this thesis represent ends of a spectrum that seem disregarded by Maclntyre and Hellstrom.

Whereas Lester (2018:79) does acknowledge some benefits to wasps, including the potential for them to help control flies and aphids. One New Zealand based company even sold wasp larvae to Japan at one point (2018:80), showing some positive economic attachment to wasps in the past. Wasp nests also provide some income for pest control businesses (2018:81), however, a financial figure was not put to this. Lester (2018:81) also discusses 'net harm' in regard to wasps. In this notion, the overall harm caused by wasps is weighed against the potential benefits they might have. However, these benefits are not yet fully explored or acknowledged in the economic impacts generated by Maclntyre and Hellstrom (2015). Compounded with the questions raised by participants, it would make good sense to explore such benefits fully before eradicating its unknown potential from our ecosystems.

Citing concerns raised in the results of this thesis, it is somewhat engrossing to consider that wasps in viticulture occupy two contrasting 'camps' of thought in this study. Furthermore, probing this notion, in response to Maclntyre and Hellstrom (2015) who found there to be no reasonable costs affiliated to the viticulture, is needed. Negative costs may be so, but what can be derived from Mātātā's interview, is that there may be a positive benefit that is currently overlooked. It is not my intention to debunk the fine work of Maclntyre and Hellstrom here, instead I want to draw attention to how impacts are calculated. Drawing on my experience during participant recruitment, I can say that it is not always easy to find the right person within an organisation who might have answers to your questions. Vineyards, as with all industries, employ people in different roles, with different knowledge e.g., customer service, sales representatives, vineyard owners (who may have different levels of vineyard contact), and vineyard managers or technicians - who are more likely to see pest management issues unfold. As a consequence, there may be unaccounted barriers to superficial research like cold calling. 
The unforeseen impacts wasps have to viticulture, both positive and negative, gives room to question literature that has influenced further study, such as this thesis. This is something to critically consider in future research, especially when dealing with sensitive, multifaceted topics like biotechnologies. To illustrate this, a brief discussion of the implications of some of the surprising findings in the results chapter will be explored in the following section. Specifically, the contrasting camps of viticulture will be agitated; the dramatic financial figures that negatively impact apiculture will be considered; and agriculture who are also said to benefit from wasp control will be reflected on. What can be deduced from these arguments is that in the future, research will need to cast a wider net in its investigations of feasibility and impacts.

\section{Viticulture and a Micro-Economy?}

Focusing on financial benefit by costing direct and indirect financial figures corresponding to wasps reveals an imbalance. An incomplete picture of the issues are constructed. The financial benefit of wasp eradication has been argued but is there a counterargument to be made?

Mātātā made the point that wasps actually make a positive contribution to his business practice by functioning as an organic pest hunter. They also mentioned that if wasps were to become unavailable, they would be uncertain about how to compensate, and would hope to find another bio-control type pest to assist in their vineyard pest management strategy. Since the vineyard has an aspiration to move away from insecticides and pesticides, there are limited ways for them to negate the unfavourable scenario of wasps being eradicated. Therefore, it can be suggested that Mātātā's relationships with wasps occupy a micro-economy.

Explained in Mātātā's interview, wasps are likely to be saving their business financially in terms of more mainstream pest solutions like insecticides and pesticides. In turn, this has a positive benefit to soil health, which they identify as a key priority in their practice. Additionally, there is potential for their pest management methods to have further financial impacts that are positive by marketing their products' value-add to environmental and health-conscious 
consumers e.g., the removal of pesticides and insecticides from the vineyard, and a focus on regenerating soil health. Dependant on the production quantity and marketing strategy, this could amount to tens of thousands of dollars in sales. Those in doubt need not look further than the trending organic and biodynamic movements in viticulture (Goode and Harrop 2011). Suddenly, the narrative of a costly wasp is balanced when considering its added benefit to some winemakers, where a positive financial impact is created.

Mātātā's micro-economic relationship with wasps may or may not be isolated. From our conversation during the interview, I am left with the impression that the benefits of wasps as a bio-control in pest management could extend elsewhere too. Contemplating this situation further could result in several micro-economies being impacted negatively in the eradication of wasps.

It is hard to imagine how far this pest management strategy extends. How many other businesses rely on bio-controls to take care of pests? Reiterated by Mātātā and the literature (Sowman 2017; Lester 2018) organic practicing businesses are likely to use such techniques. The benefit of wasps are positioned as an alternative to chemical sprays in pest management. For that reason, a future study on organic practices and bio-control pest wasps, with a focus on viticulture and fruit growers would better explain the distinctions of the potentially positive benefits of wasps.

Other participants at times questioned the value of wasps, posing thought as to what impacts on ecosystems might take place if wasps were to be eradicated. In some way, this is an extension to the thinking raised by Mātātā, and in a similar fashion, there is an imbalance to the perceived impacts wasps have. It is not clear what impact or changes, if any, would be caused if wasps were erased from Aotearoa's ecosystems. This unanswered question also speaks to the fears and opposition that participants expressed in the theme of side effects in the results chapter, furthermore, a position that speaks to previous research on Māori perceptions of biotechnology (Baker 2012; Hutchings 2004; Roberts and Fairweather 2004). 
Complicating wasp matters further in vineyards is Kākā, who expressed a dislike of German and Common wasps, however, they liked the native wasp population (although this was not elaborated on). Mātātā was unable to confirm what wasp it is that they benefit from. Subsequently, there is a need to better distinguish what variety of wasps benefit vineyard pest management.

\section{Apiculture: the Beneficiary?}

As Maclntyre and Hellstrom (2015) estimate, wasps cost Aotearoa New Zealand industries $\$ 133$ million annually. Of this sum, $\$ 57.8$ million is estimated to be an apiculture specific loss from honeydew forgone to wasps (2015:12). Naturally, it could be assumed that such a large detrimental cost to a small yet booming industry, apiculture must have a prime concern to deal with pest wasps. However, as it was revealed in the results, wasps were acknowledged to be undesirable to apiculture, despite this, they were not the priority pest in any instance of LRE1. By contrast, other pests like Argentine ants and wax moth were discussed to be more concerning, causing the most detrimental effects in honey production.

The mild priority of wasps by participants in this thesis is contrasting to the hypotheses at the beginning of this project, summated in the literature. Lester (2018:73) does contend that "[w]here wasp densities are low, few bees are killed and little money is spent on wasp control". Bearing this in mind with regard to participant's pest priorities, some scrutiny of their locations could arise. Despite this, one business interviewed was based in what can be regarded as Aotearoa's wasp mecca, the top of the South Island, where some 1 million hectares of honeydew beech forest is situated (Beggs 2001 cited in Maclntyre and Hellstrom 2015:13). Even so, the same business prioritised indirect pests as their most concerning problem in pest management.

Mohua and Tūî prioritised salmon and stoats respectively in LRE1. The mentioning of salmon is particularly perplexing given that fish have little means to affect apiculture directly. Deduced in the results chapter is a concern for environmental impact. During the interview, they drew on the negative impacts salmon farming has to the local awa (river) by defecating, compounded 
by their seemingly unnatural upbringing, in which Mohua describes salmon being pumped "...full of antibiotics". Noteworthy in this instance, is the holistic environmental outlook that takes precedence over conventional business values, such as financial imperatives. Likewise, stoats have little to do with producing honey although they do have plenty to do with reducing local native bird populations, of which they stated the importance of maintaining. This in turn led to their consent of a 1080 drop in the region. Tikanga mentioned to be affected from these examples included mauri and the ability to perform kaitiakitanga.

The results that surfaced from apiculture participants were most surprising. The lack of priority given to wasps brings into question the so-called "war on wasps". Entangled in this are notions of non-market activity, implying that financial factors take a back seat when considering pest management aspirations. Moreover, for some of the participants, a holistic approach was embraced when considering pest management. Connections to the land and ecosystems both directly and indirectly are summoned with such views. These are considerations that do not appear to be currently calculated by those at the helm of the biotechnology waka.

\section{Agriculture: Deaf to the Hum of Wasps?}

The most concerning pests identified by the single agriculture participant, Kārearea, had no direct impact on dairy production. Instead, the pests they were concerned with impacted the whenua, and specifically their non-market activity - a non-monetary profit native planting scheme. The scheme has no monetary return, instead, it is seen as a giving back to the land from which they profit in their agricultural activities.

Examining the priorities of this business reveals cultural aspirations and acknowledges sustainable practices through a kaitiaki lens. Kaitakitanga intersects with whakapapa as a role that is intergenerational with the essential task of looking after a natural resource so that it is "healthy and strong" (Mutu 2010:15). Kārearea made the point of giving back to the land being paramount, evident in their investment that has no financial return. Signalled in the results, 
this could be interpreted as a transaction with Papatūānuku (Mother Earth) (Bargh 2011). There is a desire to ensure the longevity of the resource (e.g., the land from which they farm) so that it can be passed on to future generations. Other tikanga raised in their interview alluded to mauri, indicating how healthy the whenua is - which the planting scheme has a positive influence. The cultural significance of their non-market activity highlights the connection the business has to the land. Connection to place is reiterated by whakapapa and ahi kā (fires of occupation) (Mead 2003), that are reflected in tribal histories and pre-colonial narratives.

Kārearea's concerns for pest management appear external to their business practice. They have an outward look to the local environment to gauge wellbeing, suggesting that economic factors take a backseat. Subsequently, non-market activity is prioritised over market activity in this instance. Likened to the apiculture participants, this is a surprising finding that shows great contrast to the presumptions that might be made about Māori business values. The status-quo for a long time has been that a business which operates in a capitalistic model, should focus on making profits for shareholders and upscaling. Although, with social responsibility in business on the rise ${ }^{17}$, producing businesses that fit closely to Gibson-Graham's notion of 'alternative market' transactions, Kārearea's business values seem to disrupt these terms further than anticipated. Furthermore, their views are likely to challenge preconceptions of Māori enterprise.

\section{Re-imagining Impact Calculations}

Considering concerns of participants in this study stimulates several points of discussion on what steers research. I am drawn once again to discussing the issue of calculation, since it appears that the notion of wasps having potential to benefit business or ecosystems is not yet fully explored in the lead up to PF2050. 17 pests identified by participants were unaccounted for in the PF2050 campaign. Questions allude to how the PF2050 campaign is constructed e.g.

\footnotetext{
${ }^{17}$ See, for example, the 'B Corp' movement (www.bcorporation.net).
} 
what makes a pest, a pest. Factors to consider here may be the geographical location of participants and scale of production. But what influences the 'something' to become most unfavourable, making it to the PF2050 most wanted list?

The economic impact of pest wasps is the foundation to this thesis, however, there is a sense that for a pest to be a real pest - one that is targeted by science organisations - there must be financial reason to do so. This is evident in the argument against wasps, coupled with its 'bad wrap' as a nuisance, contributes to its negative public image. Even when considering the target of mammalian creatures, economics plays a role. The eradication of these animals would enhance New Zealand's 100\% clean green brand with international tourism. I am in no doubt about the importance of bringing back the birdsong of our ngāhere (forest) but connections to financial incentives are present in the decision to eradicate pests. This is all well and good, but the findings from this thesis suggest future considerations in the discussion of pest management. What participants have raised, is a need to cast a wider net in impact calculations.

I propose that there is a need for a more balanced process when reviewing these issues. This could be achieved by future research in the field. It would be insightful for a study on the positive impacts of wasps and more broadly, other biocontrols in use across the primary industries. A comparative approach could be taken between wasps and other bio-controls. For viticulture, this could illuminate the potential Common and German wasps have in organic pest management. Additional research considerations could include a wider catchment of qualitative interviews within apiculture to better understand industry priorities and needs in pest management. As it has been revealed in the results of this thesis, the industry perspective is diverse even among a small sample of four apiculture businesses. There are nuances that may further influence this, such as the geographical location of business, and business values. These nuances are likely to be exponential if a wider study were to take place. 
The discussions posed by agriculture, apiculture, and to some extent viticulture indicate a further point of discussion - diverse economies. Although all participants showed links to aspects of the diverse economy framework, I focused on non-market activities because of the surprising results that emerged from interviews. These were prioritised by agriculture, and a single apiculture business. A call to re-imagining impact calculations reverberates among the findings of the previous sub-subsections. Such a call could provide deeper insight of the rich data generated from interviews, while making sense of it.

\section{Section Two}

\section{Diverse Economies: At the Forefront of Decision Making?}

Discussed in the literature review chapter, the work of Gibson-Graham (2006) and Bargh $(2009 ; 2011 ; 2012)$ shows that the language of a diverse economy has potential to describe a fuller picture of business practices. The literature has suggested, making use of a diverse economy framework will help to better describe Māori business practices (Amoamo 2018b; Bargh 2011). In doing so, 'success' in business is not solely located in traditional economics (Amoamo 2018b; Bargh 2011). In the context of a growing Māori economy exploring how Māori businesses operate, where values lay, and how these might impact decision making is an alluring task. Thus, I am compelled to incorporate this framework within this thesis, and endeavour to make use of it further in this chapter.

A significant finding to come from this thesis is that a random sample of Māori businesses occupy diverse economies. Drawing inspiration from Bargh (2011), Table 1 in the results chapter found connections to tikanga and Māori values via interactions with a diverse economy framework, generating one impression of the data. Interestingly, all businesses are involved in non-market activity. Digging deeper, I have pursued the use of a diverse economy framework in this chapter to see if it can help to reveal decision making markers. To do this, I have assembled two additional tables with quotes from participants. In Table 2 (pg. 91), comments relating specifically to 
biotechnology and decision making are assembled and deciphered to see if elements of the diverse economy framework, specifically non-market transactions, are kindled in decision making. I have focused on non-market activity due to its strong representation among participants, which are linked to Māori values, and anti-capitalist traits. Table 2 shows an overwhelming consideration of non-market activity in decision making on biotechnologies. Therefore, Table 3 has been produced to find evidence of market activity in decision making, to balance and solidify the results in Table 2. Following this, the implications of these tables are discussed.

\section{Defining Non-Market Activity and Tikanga}

Exploring the diverse economy definitions, centring on non-market transactions, and its relationship to tikanga seems like a worthy task at this point. As mentioned in the literature review, these relationships are already of interest by Māori scholars (Amoamo et al. 2018b; Bargh 2011). Therefore, I would like to briefly clarify the connection made between non-market activity and tikanga, and restate the definitions of transactions under a diverse economy.

Market is synonymous with capitalism in that is seeks to expand and "...has powers to penetrate and subordinate, to create subjects and desires" (GibsonGraham 2006:62). Consequently, traditional business imperatives can be garnered as market activity.

Alternative market transactions embody a socially ethical ethos, a common example being the cooperative (co-op) business model "... where prices are set to enhance the sustainability of the cooperative..." (Gibson-Graham 2006:62). Whereas non-market is far-reaching, exemplified in house work, hunting and fishing, and even theft (Gibson Graham 2006). The broad interpretations of non-market activity gives space to accommodate Mãori values, as shown in the results table, and previously demonstrated by Bargh (2011). 
Table 2. Interpretation of statements on biotechnologies

\begin{tabular}{|c|c|c|c|c|c|c|c|c|}
\hline & $\begin{array}{l}\text { Weka } \\
\text { (Fruit) }\end{array}$ & $\begin{array}{l}\text { Mātātā } \\
\text { (Wine) }\end{array}$ & $\begin{array}{l}\text { Kākā } \\
\text { (Wine) }\end{array}$ & $\begin{array}{l}\text { Pūkeko } \\
\text { (Honey) }\end{array}$ & $\begin{array}{l}\text { Mohua } \\
\text { Tūì } \\
\text { (Honey) }\end{array}$ & $\begin{array}{l}\text { Kākāpō } \\
\text { Toutouwai } \\
\text { (Honey) }\end{array}$ & $\begin{array}{l}\text { Kererū } \\
\text { (Honey) }\end{array}$ & $\begin{array}{l}\text { Kārearea } \\
\text { (Milk) }\end{array}$ \\
\hline $\begin{array}{l}\text { Māori values } \\
\text { associated to } \\
\text { non-market }\end{array}$ & Kaitiakitanga & Kaitiakitanga & $\begin{array}{l}\text { Koha } \\
\text { Hauora } \\
\text { Kaitiakitanga }\end{array}$ & $\begin{array}{l}\text { Whanaungatanga } \\
\text { Whakapapa } \\
\text { Mātauranga } \\
\text { Kaitiakitanga }\end{array}$ & $\begin{array}{l}\text { Tino } \\
\text { rangatiratanga } \\
\text { Mātauranga }\end{array}$ & $\begin{array}{l}\text { Whenua } \\
\text { Manaakitanga } \\
\text { Whanaungatanga }\end{array}$ & $\begin{array}{l}\text { Manaakitanga } \\
\text { Hauora } \\
\text { Mātauranga }\end{array}$ & Kaitiakitanga \\
\hline $\begin{array}{l}\text { Selected } \\
\text { statements on } \\
\text { biotechnology }\end{array}$ & $\begin{array}{l}\text {...unless you } \\
\text { can tell me the } \\
\text { flow-on } \\
\text { implications } \\
\text { from an } \\
\text { environmental } \\
\text { point of view } \\
\text { of completely } \\
\text { eradicating } \\
\text { wasps... }\end{array}$ & $\begin{array}{l}\text { If we were using } \\
\text { them to control our } \\
\text { Apple Moth, then } \\
\text { we'd need } \\
\text { probably } \\
\text { something else. } \\
\text { Either another bug, } \\
\text { or we'd have to use } \\
\text { an insecticide. But I } \\
\text { mean, I get, if it's a } \\
\text { big enough } \\
\text { problem for } \\
\text { everybody, then } \\
\text { it's a small } \\
\text { minority that } \\
\text { suffer. }\end{array}$ & $\begin{array}{l}\text {...and there } \\
\text { was no chance } \\
\text { of it [biotech] } \\
\text { inadvertently } \\
\text { spreading to } \\
\text { the native } \\
\text { population. }\end{array}$ & $\begin{array}{l}\text { We're dealing with } \\
\text { an issue that } \\
\text { essentially post- } \\
\text { dates many of the } \\
\text { essential elements } \\
\text { of the kaupapa we } \\
\text { work with. }\end{array}$ & $\begin{array}{l}\text { DNA modification, } \\
\text { gene slicing or } \\
\text { whatever they } \\
\text { call it, is around } \\
\text { the whakapapa, } \\
\text { the mauri, the life } \\
\text { force that } \\
\text { everything has. } \\
\text { We are just } \\
\text { worried about } \\
\text { that. }\end{array}$ & $\begin{array}{l}\text { It would make } \\
\text { them [iwi] moan... } \\
\text {... anything } \\
\text { unnatural would } \\
\text { cause a } \\
\text { conversation. }\end{array}$ & $\begin{array}{l}\text { I think as long as } \\
\text { we're not creating } \\
\text { unnecessary harm } \\
\text { and stress to the } \\
\text { insects or the animals } \\
\text { that we need to } \\
\text { eradicate for the } \\
\text { greater good, then I } \\
\text { have no problem with } \\
\text { that in terms of } \\
\text { protecting our lands } \\
\text { and making good our } \\
\text { forest and providing } \\
\text { good quality } \\
\text { chemical-free foods. }\end{array}$ & $\begin{array}{l}\text { I guess if you look } \\
\text { back at Māori } \\
\text { culture over } \\
\text { history, that's } \\
\text { never really come } \\
\text { up. It's not } \\
\text { something that } \\
\text { was ever } \\
\text { considered. }\end{array}$ \\
\hline $\begin{array}{l}\text { Interpretation: } \\
\text { non-market, } \\
\text { or market? }\end{array}$ & $\begin{array}{l}\text { Environmental } \\
\text { considerations. } \\
\text { Kaitiaki lens. } \\
\text { Non-market } \\
\text { factors in } \\
\text { decision } \\
\text { making. }\end{array}$ & $\begin{array}{l}\text { The non-market } \\
\text { methods of pest } \\
\text { management } \\
\text { control would be } \\
\text { impacted and } \\
\text { potentially force } \\
\text { them to adopt } \\
\text { market tools. }\end{array}$ & $\begin{array}{l}\text { Non-market } \\
\text { concerns are } \\
\text { reasoned } \\
\text { within } \\
\text { acceptability. } \\
\text { Kaitiaki lens } \\
\text { takes } \\
\text { precedence. }\end{array}$ & $\begin{array}{l}\text { Māori values are } \\
\text { separable from } \\
\text { decision making } \\
\text { but these values } \\
\text { are a driving force } \\
\text { in the business. } \\
\text { Non-market } \\
\text { activity is } \\
\text { considered in } \\
\text { decision process } \\
\text { but likely to not } \\
\text { affect outcome. }\end{array}$ & $\begin{array}{l}\text { Māori values } \\
\text { prioritised over } \\
\text { market factors. } \\
\text { Non-market } \\
\text { factors at play. } \\
\text { Market forces } \\
\text { take backseat. }\end{array}$ & $\begin{array}{l}\text { Consideration of } \\
\text { non-market } \\
\text { relationships (iwi) } \\
\text { are implied but } \\
\text { do not effect } \\
\text { positionality on } \\
\text { biotech. }\end{array}$ & $\begin{array}{l}\text { Non-human well- } \\
\text { being is considered. } \\
\text { Biotech is seen to as } \\
\text { better than } \\
\text { pesticides. Kaitiaki } \\
\text { non-market } \\
\text { attributes also at } \\
\text { play. }\end{array}$ & $\begin{array}{l}\text { Scenario is not } \\
\text { within the usual } \\
\text { tikanga discourse, } \\
\text { thus is perplexing. } \\
\text { Non-market } \\
\text { values are } \\
\text { therefore } \\
\text { factored into } \\
\text { consideration but } \\
\text { with no decision } \\
\text { made. }\end{array}$ \\
\hline
\end{tabular}


Even in its most superficial reading, non-market activity shows strong links to Māori concepts and practices such as mahinga kai (traditional food source), kaitiakitanga, manaakitanga (hospitality, providing for guests). In their study of Linamon, Gibson-Graham and Roelvink (2011:31) define Indigenous exchange as "ritual offerings to spirits, and "gifts" cite traditional or religious concepts both of which are located under the umbrella of non-market activity. From this definition, koha is analogous. Thus, many cultural concepts have space to occupy in a diverse economy framework.

\section{Interpretation of Statements on Biotechnologies}

Representations of the diverse economy have the potential to provoke a figure/ground shift both in visual and conceptual perception and in the emotional grasp of possibility. (Gibson-Graham 2006:68).

In the above quote, I am moved to question if this shift in focus could apply to the primary research aims of this thesis - to gauge what biotechnologies, if any, might be acceptable and on what terms. In this section, I pursue the notion of this relationship further by interrogating how and when participants make references that link to the language of a diverse economy when making decisions. Having particular regard to statements made by participants when referring to biotechnology is an engrossing starting point for this exercise. Thus, in the Table 2, statements on biotechnology have been selected from the biotech node ${ }^{18}$ in NVivo for each business. These are then analysed in the 'interpretation' row beneath, to determine what, if any, association is made to a diverse economy lexicon, thus inferring a potential connection to a diverse economy framework in decision making. It is hoped that this exercise has the potential to realise factors contributing to participant perceptions of biotechnologies.

Taking stock of comments made on biotechnology that represent moments in decision making builds the first row of the table. These statements mostly

\footnotetext{
${ }^{18}$ Themes that have been coded in NVivo.
} 
appear in the results chapter, but for some participants, additional comments have been sourced due to limited quoting. Where possible, an effort was made to use comments that neared the end of interviews, thus providing a more deliberated-upon opinion on biotechnologies. In the interpretation row, participant statements are analysed to determine if there are any direct or indirect references to non-market or market influences.

What becomes clear from examining the table is when commenting on biotechnologies in pest management, participants touch on the previously identified non-market factors. Recalling the results chapter (Table 1, pg. 79), where non-market and alternative capitalist practices of participants were linked to tikanga Māori, propels the analysis of statements in this new table.

Non-market connotations surface in different ways between the participants. For example, Kākāpō and Toutouwai consider the relationships with key asset holders; the explicit summoning of Māori values are seen in statements by Kārearea and Pūkeko; and non-tikanga specific mentioning of "an environmental point of view" still connects deeply to the non-market activities identified in the results chapter. The commonality of non-market expressions are traceable to kaitiakitanga. From this exercise it looks as though views are formed in part to the consideration of non-market activities.

\section{Market Influence in Pest Management}

To make concrete of the notion that non-market activities are present in decision making, a balancing of participant statements is needed. Given the overwhelming connection to non-market statements in the Table 2, using a contrasting parameter is necessary to reduce bias in myself the researcher. To achieve this, I looked for statements on market activity. Firstly, I searched interview transcripts for statements that intersected with market and biotechnology nodes. However, finding comments that pertained to both biotechnology and market activity was unfruitfull ${ }^{19}$, and so a wider approach

\footnotetext{
${ }^{19}$ This is likely due to my interview questions, even so, all interviews were semi-structured, and ventured into various topics, suggesting that participants had ample opportunity to express market priorities.
} 
was needed. Thus, I attempted to find participant statements relating to market activity at any point during interviews. I then interpret these statements, looking for connections to pest management decision making. The results from this exercise are presented in Table 3 (pg. 95). Some participants did not make direct references to market imperatives, instead they indicated that market forces required prior pest management decisions, thus, these statements are interpreted to be an indirect connection to pest management decisions ${ }^{20}$. One participant made no mention of market activity during the interview and so their column is left blank.

Exploring Table 3, in the first-row participant statements on market activity are presented. In the second-row, I have interpreted these statements. In row three, I have synthesised the interpretations into 'transaction connotations' where, using the diverse economy lexicon they are determined to be market, alternative market or non-market activity. Finally, a connection, if any, to pest management decision making is made.

Examining the pest management relationships in Table 3, only one business appears to show a direct relationship to market activity in pest management decision making. Weka is the sole exporter of raw fruit - no other participants have similar constraints in their practice. Exportation of honey and wine are not subject to the regulation of horticulture, and the single dairy participant only sold their product domestically.

In conclusion to both Table 2 and Table 3 exercises, it becomes evident that non-market activities play a large role in most participant decision-making in pest management. Specifically, comments made on biotechnology summoned these views (illustrated in Table 2). This is particularly evident when considering the participant expressions towards traditional market activity (Table 3) are limited. The implications of this align to the argument put forward in the previous section of this chapter, that is, what this exercise points to, is that

\footnotetext{
${ }^{20}$ By indirect I am referring to outcomes that would not be possible without having made pest management decisions.
} 


\begin{tabular}{|c|c|c|c|c|c|c|c|c|}
\hline & $\begin{array}{l}\text { Weka } \\
\text { (Fruit) }\end{array}$ & $\begin{array}{l}\text { Mātātā } \\
\text { (Wine) }\end{array}$ & $\begin{array}{l}\text { Kākā } \\
\text { (Wine) }\end{array}$ & $\begin{array}{l}\text { Pūkeko } \\
\text { (Honey) }\end{array}$ & $\begin{array}{l}\text { Mohua } \\
\text { Tūì } \\
\text { (Honey) }\end{array}$ & $\begin{array}{l}\text { Kākāpō } \\
\text { Toutouwai } \\
\text { (Honey) }\end{array}$ & $\begin{array}{l}\text { Kererū } \\
\text { (Honey) }\end{array}$ & $\begin{array}{l}\text { Kārearea } \\
\text { (Milk) }\end{array}$ \\
\hline $\begin{array}{l}\text { Market } \\
\text { activity } \\
\text { statements }\end{array}$ & $\begin{array}{l}\text { Most of our fruit } \\
\text { gets exported into } \\
\text { international } \\
\text { markets, so there } \\
\text { are really strict } \\
\text { standards for the } \\
\text { markets that we're } \\
\text { exporting to around } \\
\text { what we need to be } \\
\text { spraying for. }\end{array}$ & $\begin{array}{l}\text { We're going to do } \\
\text { some vegan } \\
\text { friendly wine this } \\
\text { year, which is going } \\
\text { to be really good as } \\
\text { well. }\end{array}$ & - & $\begin{array}{l}\text { But the focus of our } \\
\text { business is not non- } \\
\text { profit. It's definitely } \\
\text { profit. We know } \\
\text { that we can't grow } \\
\text { and keep improving } \\
\text { our business } \\
\text { without improving } \\
\text { our profit. }\end{array}$ & $\begin{array}{l}\text { Money is no } \\
\text { good for you if } \\
\text { you're sick and } \\
\text { in hospital. }\end{array}$ & $\begin{array}{l}\text { Controlling our } \\
\text { DOC lands, our iwi } \\
\text { lands, that's } \\
\text { sustaining our } \\
\text { supply... that's } \\
\text { where our } \\
\text { resources are. }\end{array}$ & $\begin{array}{l}\text { I think there's a big } \\
\text { emphasis around } \\
\text { everybody we touch } \\
\text { and do business } \\
\text { with, we do so in a } \\
\text { sort of whanaunga } \\
\text { manner. }\end{array}$ & $\begin{array}{l}\text { With an ultimate } \\
\text { goal of having our } \\
\text { own products in the } \\
\text { supermarkets...it } \\
\text { might be milk, it } \\
\text { might be red meat. }\end{array}$ \\
\hline Interpretation & $\begin{array}{l}\text { International } \\
\text { markets influence } \\
\text { production and } \\
\text { consumer relations. }\end{array}$ & $\begin{array}{l}\text { Brand growth is } \\
\text { acknowledged by } \\
\text { expanding potential } \\
\text { customer base. }\end{array}$ & - & $\begin{array}{l}\text { Commercial } \\
\text { imperatives are not } \\
\text { ignored. Traditional } \\
\text { market practices } \\
\text { are crucial to } \\
\text { growth. }\end{array}$ & $\begin{array}{l}\text { Commercial } \\
\text { imperatives } \\
\text { take a back } \\
\text { seat. Instead, } \\
\text { hauora } \\
\text { (wellbeing) is } \\
\text { prioritised. }\end{array}$ & $\begin{array}{l}\text { Production is at } \\
\text { the mercy of } \\
\text { resources, raising } \\
\text { notions of } \\
\text { respect, and a } \\
\text { need to preform } \\
\text { kaitiakitanga. }\end{array}$ & $\begin{array}{l}\text { Tikanga is ingrained } \\
\text { into how business } \\
\text { is conducted, } \\
\text { altering market } \\
\text { perspectives. }\end{array}$ & $\begin{array}{l}\text { Desires to reach a } \\
\text { particular scale of } \\
\text { production and be } \\
\text { readily available at } \\
\text { mainstream vendors. }\end{array}$ \\
\hline $\begin{array}{l}\text { Transaction } \\
\text { connotations }\end{array}$ & Market & Market & - & Market & Non-market & Non-market & Alternative Market & Market \\
\hline $\begin{array}{l}\text { Pest } \\
\text { management } \\
\text { relationship }\end{array}$ & $\begin{array}{l}\text { Direct relationship } \\
\text { to market activity } \\
\text { and pest } \\
\text { management. }\end{array}$ & $\begin{array}{l}\text { No relationship as } \\
\text { vegan wines are } \\
\text { defined by omitting } \\
\text { animal products in } \\
\text { the finishing } \\
\text { processes. }\end{array}$ & - & No relationship. & $\begin{array}{l}\text { No pest } \\
\text { management } \\
\text { relationship yet } \\
\text { a distinctive } \\
\text { non-market } \\
\text { priority. }\end{array}$ & $\begin{array}{l}\text { Indirect } \\
\text { relationship to } \\
\text { pest } \\
\text { management. No } \\
\text { market link. }\end{array}$ & No relationship. & $\begin{array}{l}\text { Indirect relationship } \\
\text { to pest management } \\
\text { decisions. }\end{array}$ \\
\hline
\end{tabular}


businesses in this study are not remotely bound up by economic factors when expressing perceptions on biotechnologies. When considering the acceptability of biotechnologies, participants found refuge in contemplating non-market activities over traditional market objectives. This is significant in that it puts into question the influential factors that contribute to steering decision making in the wider industry. These are considerations that should be taken into account when constructing future 'initiatives' that target specific industries, particularly where Māori businesses are represented.

\section{Implications of Tables}

From the analyses made in the results and discussion tables, the non-market references made by businesses are interchangeable with tikanga values. Furthermore, it appears that the non-market activities identified in this thesis are for the most part associated with the practice of kaitiakitanga, in this sense, a priority among participants can be understood. Other tikanga identified include whakawhanaungatanga, manaakitanga, and tino rangatiratanga, launching considerations for how Māori businesses might function. Participants operate to include these various values where possible and suitable to their business. These tikanga manifest in non-market and alternative market frameworks when considering the diverse economy language. Two points emerge from these findings: firstly, that kaitiakitanga is a value carried across the majority of Māori businesses in this thesis; secondly, the diverse economy language look to be interchangeable with tikanga in most instances. In the following section, these points will be discussed.

\section{Relationships to Land}

The almost unanimous ${ }^{21}$ representation of kaitiakitanga in non-market activities identified in the previous tables, poses an intriguing point of discussion. Referring back to Bargh (2011:64) and her analysis of Tuaropaki

\footnotetext{
${ }^{21}$ In the initial results exercise, Table 1, only two participants show no link to kaitiakitanga in their non-market/alternative market examples. However, Table 3 in this chapter links kaitiakitanga to the statements that were intended to gather market activity. In Table 2, nonmarket activities are connected to statements, showing only Kākāpō and Toutouwai to have links to kaitiakitanga.
} 
Power Company, which maps diverse economy layers in business, drawing comparison to non-market activity and kaitiakitanga as potentially representing a "...transaction with Papatūānuku (Mother Earth) replenishing". The same could apply to the references made by participants in this study e.g. riparian planting - which actively enhances the land and can be interpreted as this kind of transaction. Considering 'transactions with Papatūānuku' inspires additional exploration of relationships to land. In addition to this notion, parallels can be drawn to Gibson-Graham's (2006) emphasis on the importance of 're-socialising the economy', in order to combat the individualistic nature of neo-liberalism and capitalism, and in doing so, encourage a 'commons' where ethical considerations are brought to the fore in economic relations. Commons, refers to access of natural resources like land, water, air and shelter. Gibson-Graham (2006:96) extends these definitions to “...agricultural land, a gene pool, an atmosphere, a wilderness, a database, a fishery, the Internet, community facilities and support systems, or even whole set of relationships comprising a community economy...". In doing so, generates conflict with the previous literature that shows the intersection of whakapapa and genetics to be of concern to Māori (Hudson et al. 2007; Hutchings and Reynolds 2004; Roberts et al. 2004; Taupo 2012); also implicated are issues of data sovereignty (see Kukutai and Taylor 2016). Commons as a theory is also subject to criticism from Indigenous scholars (see Mercier 2013). Therefore, not adopting 'commons' as a means to interrogate transactions with Papatūānuku is for the best; while acknowledging aspects of the concept may help to imagine the relationships Māori have with the land through a nonMāori lens.

The non-market activity of participants in this study are embedded in ethical considerations. With particular regard to kaitiakitanga, a cultural concept that should not be reduced to sustainability and conservation ${ }^{22}$, but can still be connected with these 'mainstream' indicators, alluding to the potential of

\footnotetext{
${ }^{22}$ I make this call in regards to the diluted definitions of Kaitiakitanga that populate policy and general knowledge, where Māori are reduced to "stakeholders" (see Muru-Lanning 2016:120146).
} 
further invoking a commons. To illustrate this, commons, in this situation refers to the once communal spaces people occupied for sustenance and residency (reclaim the commons cited in Gibson-Graham 2006:96). There is a most obvious link to the whenua (land) and all that encompasses it (resources) e.g. the ngāhere, and fertile grounds. In the Māori world view, a connectedness to the whenua from which we have whakapapa (genealogical links) and are returned to posthumously (see Mead 2003). Furthermore, considering the tikanga relationship to land in pre-colonial times, relationships to the land were communal, influenced by iwi dynamics. Concepts such as tūrangawaewae (standing place) and ahi kā (fires of occupation), whakapapa determined ones relationship to the land - unlike the Eurocentric definitions of ownership that resulted in individual titles of land, and the subjugation of Indigenous forms of communal ownership during the colonial project (see Williams 1999; Sorrenson 2014). The same colonial project has spurred on the neo-liberal globalisation that continues to unfold today (Jackson 2007). Utilising aspects of a 'commons' as a lens for considering Māori ways of knowing pre-settlement draw further parallel in the work of Gibson-Graham and deploying a diverse economy framework in a kaupapa Māori research project. Although imperfect, it is hoped that this brief inquest of the commons may reveal additional ways to unpack relationships to land.

\section{Diverse Economies: A Language for the Present}

Reflecting on the theory of an 'economy of mana', coined by Hēnare (2014), where tikanga values are forefront in business, the diverse economy framework, although not explicitly mentioned, is open to dispute when comparing the two. Dell et al. (2018:60) builds on an economy of mana, describing the need for "...imagining a utopian shared vision for Māori economic futures". Mana is argued to be the defining aspect of a Māori economy, one worth considering over the current capitalistic modes of thinking (ibid.). However, this utopian vision is likely to have several challenges. First and foremost, banding together Māori would require extensive wānanga and education across the diverse population that Māori are today. Secondly, such 
advancements would suggest a dramatic progress in Crown-iwi relationships. If the Treaty settlement process is anything to go by (see Joseph 2012; Mutu 2012; Te Aho 2008; Muru-Lanning 2016), this is an impractical step forward.

An economy of mana seeks to negate capitalism so that Māori values can prosper in business. Dell et al. (2018:60) justly demonstrates that their utopian economy is a response to the current economic climate:

To simply aim for better educational outcomes and better career prospects without defining, articulating or visioning the preferred economy to achieve that risks perpetuating actions and behaviours common in the capitalist colonial system. (Dell et al. 2018:60).

Furthermore, their call to explore Māori sub-economies like “...kapa haka, tangi and marae..." (2018:60), have the potential to reveal new ways of operating. And so an economy of mana should not be fully disregarded. Although it does not prove to be tangible in the immediate future, like Dell et al. (2018) suggests, work is needed to develop such a pathway. To truly negate capitalism, currently, is a near impossible task. By contrast, a diverse economy language enables ways to describe and negotiate spaces that use, dispute, and disrupt capitalism. However, as the businesses in this study show, these anti-capitalist actions (specifically non-market activity) can only come about due to their previous encounters with the traditional market place. Trading goods enables profits to be redistributed into these non-market ventures. Dell et al. (2018) calls to investigate cultural sub-economies, which speculatively could offer further inspiration for the disruption of capitalism, yet it is unlikely to completely dislodge its grip. To take this idea further, tino rangatiratanga (Māori sovereignty) would need to be accepted by New Zealand's contemporary society. This would also imply a formal compliance to the Māori text of Te Tiriti of Waitangi. Nonetheless, this is a utopian vision.

The diverse economies framework validates Māori methods in business, in this thesis. The diverse economies frameworks help give perspective on the complex nature of Māori businesses. It allows for a greater understanding as to where energy is dispersed among Māori business practices. The language of diverse economies may not be utopian, but it is practical in how it permits 
tangibility, where current Māori business practices are made physical in today's economic climate, the neo-liberal era, or as Gibson-Graham describe: capitalocentrisim. Disrupting capitalism is a somewhat unthinkable task at present, as the world we know today is founded on its core values, and embedded in key international relationships. Therefore, at this time, it seems most appropriate to make use of a diverse economy lexicon to describe how Māori operate in business. Fully exploring a diverse economy framework could act as a launch-pad to future frontiers like an economy of mana.

Put simply, "a diverse economy approach demonstrates that companies, Māori or otherwise, are not simplistically capitalist or non-capitalist but contains multiple forms of transactions, labour, resource, and property ownership" (Bargh 2011:65). The results from the investigation of participant comments, placed against the framework of a diverse economy also reveals this to be true.

\section{Section Three}

\section{Communication}

From the results chapter, several themes identified intersect with the issue of science communication. Notably, participants brought to the fore a need for clear and balanced information on biotechnologies going forward. The need for more information formed the largest category of participant 'camps' or views. From participant statements, concerns were raised as to how targeted these biotechnologies are, and whether there is risk attached to their release that might impact nature or current pest management strategies. This position echoed the "uncertain Māori" in Te Momo's (2007) study. Gathering these concerns in conjunction with the need for more information indicates a very real responsibility as to how science moves forward in communicating novel biotechnologies.

Participants in this thesis were mostly unfamiliar with concepts like gene drive, with the exception of one participant who had a science background. Concurrently, technologies like CRISPR Cas9 are gaining international prominence, as identified in the introduction chapter. And so the question 
arises, how is the science community currently communicating these biotechnologies? And, are there improvements required in communication strategies to move forward?

\section{Current Strategies}

Te Apārangi The Royal Society, have conducted nationwide 'workshops' in which they have communicated gene editing scenarios to the 'general public'. However, having attended one of these sessions in Wellington, I personally assessed that the audience for the session I attended was largely exclusive, representing 'stakeholders' (from government and tertiary education), public servants, scientists and other tertiary educated experts. The sessions resulted in several publications that are intended to behave as discussion documents (see Te Apārangi 2018a; 2018b). Public engagement peaked with a series of hour long discussion panels facilitated by Radio New Zealand personality Kim Hill, in association with Royal Society. However, these sessions and discussion documents are circulated in the sphere of science enthusiasts, creating an insular conversation. This limits public engagement from organisations, individuals and businesses. Therefore, it comes as little surprise that the majority of participants have not heard of these biotechnologies before partaking in my interviews.

Legislated into law, "[T]he object of the Society is the advancement and promotion in New Zealand of science, technology, and the humanities" (Royal Society of New Zealand Act 1997). The word promotion is open to interpretation, as with all policy. The "objective" of the Royal Society is comparable to a public relations agency for science. "Advancement" can further be interpreted as a need for acceptability to advance any matter deemed important to the Society.

Although the work of Te Apārangi Royal Society can be criticised for its inaccessibility, it should also be recognised that they are a major supporter of science in Aotearoa, which is beneficial. I am merely suggesting that their communication strategies to the general public needs attention and reinvention. However, if the Society does in fact work like that of a public 
relations consulting firm, then a sense of pushing new 'products' through advertisement can be perceived. Subsequently, new strategies of communication that are meaningful are required. This echoes the needs of participants who asked for collaboration and partnership, some of which, had previously encountered in their consultation and collaboration with $\mathrm{DOC}$ in a 1080 drop.

As implied, the challenge that lays ahead will be one of communication and consultation with the general public, Māori, and industries that are one of many 'beneficiaries' of any potential biotech release. Dearden et al. (2018:237) emphasise that science must only move forward by letting the concerns of the public inform research. However, this has recently been complicated by Minister for Conservation, Eugene Sage, who has recently come out in opposition to GE technologies as a potential solution for the PF2050 campaign (Alexander and Bracewell-Warrell 2019). Sage's position questions years of work in the space of innovate pest management by academics, including gathered thoughts of the public, like this thesis; in turn, Sage resembles a totalitarian conservationist disengaged with public opinion. Assuming Sage's roadblock is lifted, developing communication with the public will be key. Bearing this in mind, returning to another theme from the results 'drawing on past experiences' may offer guidance to this future conversation. Most obviously, the on-going controversy that is 1080 .

\section{Drawing on Past Experiences}

Further Illuminating viewpoints on 1080 could construct a landscape to discuss biotechnologies in the future. As mentioned in the results chapter, some participants drew on past experiences with 1080 during interviews. Although 1080 was not included in any specific interview question, it was rendered as an example of a 'non-species specific poison' in LRE2 which took place at the beginning of the interview. With the benefit of semi-structured interviews, tangents of conversation often led to participant's self-described positionality on 1080. Some interviewees recalled experiences with 1080 and the release of 
calicivirus, highlighting that participants look back to previous pest management events when considering new strategies.

As has been the case with 1080 , the significance of one participant's opinion being informed by social media cannot be underestimated. Social media is now a powerful tool in public relations, advertisement, and fake news (OECD 2019). In addition to this, social media users often end up in an "echo chamber" of their own positionalities, leaving little room to take on new ideas. The social media influence re-articulates Roberts and Fairweather's (2004) findings of media influencing opinions of biotechnology. Shifts in media trends and sources demand an up-to-the-minute critique of media consumption and its influence.

Māori perceptions of biotechnology is the subject of this thesis, however, the mystery that surrounds misconceptions of 1080 could potentially yield more insight in how to approach communications of science in the future. Green and Rohan (2012) show that "information silos" create uneven communication on 1080 issues by relevant agencies. They argue mitigating 1080 concerns will only come from meaningful 'risk communication' with communities (ibid.). Further exploration of successful 1080 partnerships in communities, like that highlighted by Kākāpō and Toutouwai could shed light on the anti-1080 personas, giving guidance on how to proceed with a conversation on biotechnologies.

Another issue of science communication arises when considering the 'primer' document for this study. The primer was produced by Alan King-Hunt, with some edits on my part, to provide participants with an overview of the complex biotechnologies. Participants were emailed the primer when liaising about interview times. This was typically bundled into interview confirmation emails too. It was hoped that the primer would prepare participants for the biotechnologies they were to be interviewed about, and also put at ease any technical questions they might have regarding the scientific content. It may come as a surprise to some that few participants read the five page primer 
document. Only two participants explicitly referred back to the document during interviews.

Questioning why participants might not have read the primer may offer clues to how these biotechnologies are communicated going forward. Firstly, it should be acknowledged that the majority of the businesses interviewed were small to medium operations. The people interviewed, were busy, skilled, and in demand to their business. Acknowledging that most participants may just not have had the time to read the document is important, and fair. On the flipside, there is the possibility that some participants attempted to engage with the primer, but found it alienating or irrelevant. This is likely due to the verbatim nature of the primer document, which is built from scientific journals. Reflections on the effectiveness of the primer suggests that printed text media might not be the best way to communicate complex ideas to a broad audience.

\section{Conclusion}

Over the course of the three sections in this chapter, several implications of this thesis have been explored concerning impact calculations, non-market expressions and their implications, and issues of communication. In the next chapter, this thesis concludes, reviewing the main findings and implications. 


\section{Conclusion}

\section{Aims and Outcomes}

The primary aim of this thesis was to gauge how Māori businesses feel about the five proposed novel biotechnologies and their deployment as a means for pest wasp management. Participant views loosely form three camps or positions on this matter: accepting; a need for more information; and disapproving. The largest catchment, a need for more information, expressed this need for information as a requirement before proceeding to make any concrete decision on biotechnologies. Participant views speak back to the previous academic work in the field of Māori and GE, GM, and biotechnology, and in some cases show parallels to the work of Te Momo (2007), and Roberts and Fairweather (2004). In turn, a discussion emerged in the previous chapter on issues of information clarity and science communication, to establish balanced and unbiased information. Also noted was the influence of previous pest management experience, and how this might help to inform future communication strategies. Wasps also appeared to not be the priority pest in apiculture - a surprising result.

The second aim of this thesis was to find out which, if any, of the five novel biotechnologies were acceptable in pest management to Māori businesses, and if so, on what terms. The only clear result is that the majority of participants remain undecided and awaiting further information before deciding on the acceptability of biotechnologies. Only one participant expressed explicitly acceptance of biotechnology. However several participants expressed interest in the technologies. Additionally, no clear favourite emerged from the Likert ranking exercise. However, some moments in the data suggest more interest in pheromones and gene drive.

Thirdly, this thesis sought to uncover Māori business involvement in diverse economies, and explore the relevance of a diverse economy framework in decision making. Significantly, this thesis, has revealed that eight randomly sampled Māori businesses all share interests in layers of a diverse economy, 
evident in their non-market and alternative market activities. Diverse economy language accommodates Māori values and concepts in business, reiterating notions from the literature (Amoamo et al. 2018b; Bargh 2011).

In the results chapter, I linked business actions to aspects of the diverse economy language via table 1. All businesses had actions linked to Māori values and tikanga. Building on these findings, an experimental approach to further revealing information in decision making was explored in two additional tables. In the discussion chapter, table 2 and table 3 demonstrated that non-market activity is a factor in decision making on biotechnologies among participants. Additionally, concerns for non-market activities are prioritised over traditional market imperatives.

These findings show potential for future exploration in understanding positionalities in Māori business. The utilisation of a diverse economy framework should continue to be explored as a tool to understand the links between value systems, business activities, and decision-making.

\section{Research Reflections}

The use of a kaupapa Māori mixed-method approach in this thesis was appropriate for participants, and elicited unique and revealing results. Likert ranking exercises warmed participants to the kaupapa, stimulated conversation with participants, revealed unexpected interpretations of pests, and acted as touchstones for complex topics during the interview. In the application of kaupapa Māori, it was discerned that there are subtle, situational, differences that should be dealt with sensitively to ensure cultural safety for all who take part in the research process.

A surprising outcome of this research is the somewhat underwhelming concern for wasps by participants. Two key moments in the data best illustrate this. The first being that none of the apiculture participants ranked wasps as their number one concerning pest. The second being, the viticulture participant who finds wasps to be beneficial to their pest management strategies, likely to contribute to a micro-economy. Furthermore, two of the apiculture 
participants prioritised pests that had no effect on the production of honey, instead they engaged a holistic outlook on environmental issues, highlighting the complexity in decision making among participants.

There is a clear need for further research into the potential use of wasps as biocontrols of aphids and other undesirable pests in fruit growing industries. Considering the micro-economy associated with wasps controlling pest in organic production methods, is likely to reveal savings on pesticides and insecticides, across an unknown amount of businesses, that could also amount to dramatic figures like that of MacIntyre and Hellstrom's (2015) economic impact study. Furthermore, future research needs to weigh itself against alternative forms of calculation. Can economic factors alone be enough to make a decision like eradicating wasps from Aotearoa? And if so, shouldn't the economic benefit also be explored and presented to show both sides of the argument?

\section{Where to Next?}

The findings of this thesis have suggested that further research is required to re-imagine how economic value is calculated. Currently, negative economic impacts are documented but the positives are not. As probed in the discussion chapter, an unknown amount of micro-economies may exist, posing potentially positive economic impacts. An imbalance can be seen when considering the lack of research that seeks alternative views on the situation.

This thesis has given a voice to Indigenous people who operate within capitalist systems, otherwise described as capitalocentric by Gibson-Graham (2006). As a result, nuances on pest management have been highlighted, showing holistic views that extend beyond returning a profit. It is clear that a re-imagining in impact calculations is needed to make space for these views in future research. The fields of research that could benefit from this are endless. When considering a social science lens, a starting point could be as simple as querying the subject that has been lit in a negative light. As Carter et al. (2011) suggests in their call to move beyond GDP calculations, a similar outlook can be taken 
on all forms of calculation. With more variations in the type of data generated, a more complete view can be made on the issues at hand. Combining tools of the academy: quantitative studies, qualitative studies, kaupapa Māori, mixedmethod; has the potential to create deeper insights.

Science, and government, those who have great influence in where biotechnologies will head next, need to collaborate with Māori, and other members of the public, and industry in meaningful ways to establish if the "need" for these techniques is felt at a grass roots level. Previous advancements in pest management like 1080 and the calicivirus have left a negative impression on industry in this thesis and arguably elsewhere in society. As one participant highlighted, there is a possibility to achieve collaboration between iwi organisations and conservation efforts. Looking upon these successes will further enhance the chances of a harmonious response to new pest management strategies in the future. Until then, avoiding a rehash of polarising, now political events of the past, will be crucial to the success of PF2050 and future challenges to pest management. 


\section{Bibliography}

AgPest. n.d.. Grass-grub, brown beetle larvae. [Image]. [Accessed 14 Feb 2019]. Available from: http://agpest.co.nz/?pesttypes=grass-grub-brownbeetle-larvae

Alexander, M., \& A. Bracewell-Worrall. 2019. Govt blocking breakthrough technology that could make New Zealand predator-free. [News item]. $\begin{array}{lllll}\text { [Accessed } & 19 & \text { Feb } & \text { 2019]. }\end{array}$ https://www.newshub.co.nz/home/politics/2019/02/govt-blockingbreakthrough-technology-that-could-make-new-zealand-predatorfree.html

Amoamo, M., Ruckstuhl, K. \& D, Ruwhiu. 2018a. Balancing Indigenous Values Through Diverse Economies: A Case Study of Māori Ecotourism. Tourism Planning \& Development, 15 (5): 478-495.

Amoamo, M., Ruwhiu, D. \& L, Carter. 2018b. Framing the Māori Economy: The complex business of Māori business. MAl Journal, 7 (1): 66-78.

Amohanga. 1999. Statement of Evidence to ERMA in the matter of application for Approval to Field Test in Containment Any Genetically Modified Organism (AgResearch).

Anderson, C., \& T. Kukutai. 2016. Reclaiming the statistical "native" Qualitative historical research beyond the pale. [Electronic Book]. In: C. Anderson and J. M. O'Brien (eds). [Accessed 3 May 2018]. Available from: https://www.taylorfrancis.com/books/e/9781315528847

Anomaly, J. 2018. Defending eugenics. Monash Bioethics Review, 35 (1-4): 2435.

Armelagos, G. J. 2012. Anthropology and the Genographic Project. American Anthropologist, 114 (1): 140-142.

Australia New Zealand Food Standards (ANZFS). 2000. Application A338 Glyphosate tolerant soybean GTS 40-3-2. [Online]. [Accessed 14 May 2018].

Available from: 
http://www.foodstandards.govt.nz/code/applications/documents/A338 FAR.pdf.

Australia New Zealand Food Standards (Anzfs). 2016. Genetically modified (GM) food labelling. [Online]. [Accessed 14 May 2018]. Available: http://www.foodstandards.govt.nz/consumer/gmfood/labelling/Pages/ default.aspx

Awang, S. 2000. Indigenous Nations and the Human Genome Diversity Project. In: Dei, G. S., Hall, B. and D. G. Rosenberg, (eds.), Indigenous Knowledges in Global Contexts. Toronto: University of Toronto Press, pp. 120-136.

Baker, M. 2010. The Korowai Framework: Assessing GE through the Values the ART Confederation Associates with Ngārara. MA Thesis, Victoria University of Wellington.

Baker, M. 2012. The Korowai Framework: assessing GE through tribal values. New Genetics and Society, 31 (1): 87-98.

Bargh, M. \& O. Jacob 2009. Progressive spaces of neoliberalism in Aotearoa: A genealogy and critique. Asia Pacific Viewpoint, 50 (2): 154-165.

Bargh, M. 2007. A Small Issue of Sovereignty. In: M. Bargh (ed.) Resistance: An Indigenous Response to Neoliberalism. Wellington, N.Z.: Huia, pp. 147166.

Bargh, M. 2011. The Triumph of Māori Entrepreneurs or Diverse Economies. Aboriginal Policy Studies, 1 (3): 53-69.

Bargh, M. 2012. Rethinking and re-shaping indigenous economies: Māori geothermal energy enterprises. Journal of Enterprising Communities: People and Places in the Global Economy, 6 (3): 271-283.

Bargh, M. 2014. A Blue Economy for Aotearoa New Zealand? Environment, Development and Sustainability, 16 (3): 459-470. 
Barnes, H. M. 2000. Kaupapa Māori: explaining the ordinary [Online]. [Accessed 20 Nov 2018]. Available: http://www.rangahau.co.nz/assets/BarnesH/explaining_the_ordinary.pdf.

Beaton, A., Hudson, M., Milne, M., Port, R V., Russell, K., Smith, B., Toki, V., Uereta, L., Wilcox, P., Bartholomew, K., \& Wihongi, H. 2017. Engaging Maori in biobanking and genomic research: a model for biobanks to guide culturally informed governance, operational, and community engagement activities. Genetics in Medicine, 19 (3): 345-351.

Beggs, J. R. 2001. The ecological consequences of wasps (Vespula spp.) invading an ecosystem that has abundant carbohydrate resource. Biological Conservation: 99 17-28.

Beggs, J. R., Karl, B. J., Wardle, D. A. \& Bonner, K. I. 2005. Soluble carbon production by honeydew scale insects in a New Zealand beech forest. New Zealand Journal of Ecology, 29 (1): 105-115.

Beggs, J. R., Karl, B. J., Wardle, D. A. \& Bonner, K. I. 2005. Soluble carbon production by honeydew scale insects in a New Zealand beech forest. New Zealand Journal of Ecology, 29 (1): 105-115.

Bendal, P. n.d.. Costelytra zealandica. [Image]. [Accessed 14 Feb 2019]. Available from: http://ketenewplymouth.peoplesnetworknz.info/image_files/0000/001 2/8273/Costelytra_zealandica____.JPG

Bishop, R. 1998. Freeing ourselves from neo-colonial domination in research: A Māori approach to creating knowledge. International Journal of Qualitative Studies in Education, 11 (2): 199-219.

Bishop, R. 2008. Te Kotahitanga: Kaupapa Māori in Mainstream Classrooms. In: K. N. Denzin, S. Y. Lincoln, \& L. T. Smith (eds.), Handbook of Critical and Indigenous Methodologies. Thousand Oaks, California: SAGE Publications, Inc., pp. 439-458. 
Brown, K. V. 2019. Major DNA Testing Company Sharing Genetic Data with the FBI. [Online]. [Accessed 13 Feb 2019]. Available: https://www.bloomberg.com/news/articles/2019-02-01/major-dnatesting-company-is-sharing-genetic-data-with-the-fbi.

Campbell, H. 2004. Organics ascendant: Curious resistance to GM. In: R. Hindmarsh \& G. Lawrence (eds.) Recoding Nature. Sydney, NSW: University of New South Wales Press, pp. 41-52.

Carson, J. 2017. The Weapon to Wipeout Wasps: The Story of Vespex. [News Item]. [Accessed 10 Feb 2019]. Available: https://www.stuff.co.nz/environment/wasp-wipeout/87865462/the-weaponto-wipe-out-wasps-the-story-of-vespex--wasp-wipeout.

Carter, L., R. Kamau \& M. Barrett. 2011. Te Pae Tawhiti Māori Economic Development Programme Literature Review and Programme Report. [Online]. [Accessed 25 June 2018]. Available: http://www.maramatanga.co.nz/sites/default/files/Maori\%20Economic \%20Development_final_web.pdf.

Chapman Tripp. 2017. Te Ao Māori Trends and Insights. [Online]. [Accessed 18 April 2018]. Available: http://www.chapmantripp.com/Publication\%20PDFs/2017\%20Chapma n\%20Tripp\%20Te\%20Ao\%20Maori\%20\%20trends\%20and\%20insights\%20E-VERSION.pdf.

Chilisa, B. 2012. Indigenous Research Methodologies, Thousand Oaks, California, Sage.

Chomsky, N. 2004. Letters from Lexington: Reflections on Propaganda. Colorado: Paradigm Publishers.

Coombes, B. 2013. Indigenism, Public Intellectuals, and the Forever Opposed Or, the Makings of a "Hori Academic". In: D. M. Mertens, F. Cram, and B. Chilisa (eds.), Indigenous Pathways into Social Research: Voices of a New Generation. Walnut Creek, California: Left Coast Press, pp. 77-88. 
Cram, F. 2001. Rangahau Māori: Tōna tika, tōna pono - The validity and integrity of Māori research. In: Tolich, M. (ed.), Research Ethics in Aotearoa New Zealand: concepts, practices, critique. Auckland, N.Z.: Longman, pp. 3552.

Cram, F. 2005. Backgrounding Maori Views on Genetic Engineering. In: J. Baker (ed.), Sovereignty Matters. USA: University of Nebraska Press, pp. 51-66.

Cram, F., \& D. M. Martens, 2015. Transformative and Indigenous Frameworks for Multimethod and Mixed Methods Research. In: S. Hesse-Biber \& R. B. Johnson (eds.), The Oxford Handbook of Multimethod and Mixed Methods Research Inquiry. New York, NY: Oxford University Press, pp. 91109.

Dearden, P. K., Gemmell, N. J., Mercier, O. R., Lester, P. J., Scott, M. J., Newcomb, R. D., Buckley, T. R., Jacobs, J. M. E., Goldson, S. G. \& D. R. Penman. 2018. The potential for the use of gene drives for pest control in New Zealand: a perspective. Journal of the Royal Society of New Zealand, 48 (4): 225-244.

Dell, K., Staniland, N., \& A. Nicholson 2018. Economy of Mana: Where to next? MAl Journal, 7 (1): 51-65.

Denzin, K. N. \& Y. S. Lincoln. 2010. Introduction: The Discipline and Practice of Qualitative Research. In: K. N. Denzin and Y. S. Lincoln (eds.), The SAGE Handbook of Qualitative Research. Thousand Oaks, California: SAGE, pp. 1-19.

Denzin, K. N. 2008. Introduction: The Discipline and Practice of Qualitative Research. In: K. N. Denzin and Y. S. Lincoln (eds.), The Landscape of Qualitative Research. Thousand Oaks, California: Sage, pp. 1-44.

Deparment of Conservation [DOC]. n.d. Red deer stag. [Image]. [Accessed 14 Feb 2019]. Available from: Red Deer. https://www.doc.govt.nz/nature/pests-and-threats/animal-pests/deer/. 
Department of Conservation [DOC]. 2000. The New Zealand Biodiversity Strategy. [Online]. [Accessed 28 May 2018]. Available: http://www.mfe.govt.nz/publications/biodiversity/new-zealandbiodiversity-strategy.

Department of Conservation [DOC]. 2014. Wild boar. [Image]. [Accessed 14 Feb 2019]. Available from: http://www.pestdetective.org.nz/image?Type=culprit\&ID=59\&Parent=1 21.

Department of Conservation [DOC]. 2015. Wasp bait more widely available to the public. [Online]. [Accessed 10 Feb 2019]. Available: https://www.doc.govt.nz/news/media-releases/2015/wasp-bait-morewidely-available-to-the-public/.

Department of Conservation [DOC]. 2019. Animal pests A-Z. [Online]. [Accessed 12 Jan 2019]. Available: https://www.doc.govt.nz/nature/pests-andthreats/animal-pests/.

Durie, M. 2011. Ngā Tini Whetū: Navigating Māori Futures, Wellington, N.Z.: Huia.

Durie, M. 2012. Interview. Kaupapa Māori: Shifting the social. New Zealand Journal of Educational Studies, 47 (2): 21-29.

Edwards, E., Toft, R., Joice, N. \& I. Westbrooke. 2017. The efficacy of Vespex ${ }^{\circledR}$ wasp bait to control Vespula species (Hymenoptera: Vespidae) in New Zealand. International Journal of Pest Management, 63 (3): 226-272.

Edwards, P. \& S. Trafford. 2016. Social licence in New Zealand-what is it? Journal of the Royal Society of New Zealand, 46 (3-4): 165-180.

Edwards, P., Fleming, A., Lacey, J., Lester, L., Pinkard, E., Ruckstuhl, K., Bezuidenhout, C., Payn, T., Bayne, K. \& Williams, T. 2019. Trust, engagement, information and social licence-insights from New Zealand. Environmental Research Letters, 14 (2): 1-9. 
Etzioni, A. 2010. Reflections of a sometime-public intellectual. PS: Political Science and Politics, 43: 651-655.

Fedoroff N. \& N. M. Brown 2004. Mendel in the Kitchen: A Scientists View of Genetically Modified Foods, Washington, D.C., Joseph Henry Press.

Gibbs, N. 1996. Genetically modified organisms and Māori cultural and ethical issues, Wellington, N.Z., Ministry for the Environment.

Gibson-Graham, J. K. 2006. A Postcapitalist Politics, Minneapolis: University of Minnesota Press.

Gibson-Graham, J. K. \& G. Roelvink. 2010. An Economic Ethics for the Anthropocene. Antipode 41 (S1): 320-346.

Gibson-Graham, J. K., \& G. Roelvink. 2011. The Nitty Gritty of Creating Alternative Economies. Social Alternatives, 30 (1): 29-33.

Goode, J., \& S. Harrop. 2011. Authentic Wine, Berkley: University of California Press.

Green, W. \& Rohan, M. 2012. Opposition to aerial 1080 poisoning for control of invasive mammals in New Zealand: risk perceptions and agency responses. Journal of the Royal Society of New Zealand, 42 (3): 185-213.

Hall, M. 2014. Rethinking Māori Academic Development in New Zealand Universities, Thesis (PhD.), Victoria University of Wellington.

Hall, N. \& Jeanneret, T. 2015. Social licence to operate: An opportunity to enhance CSR for deeper communication and engagement. Corporate Communications, 20 (2): 213-227.

Hallam, A. 2004. Human genomics and health care: Questioning the biomedical approach. In: R. Hindmarsh \& G. Lawrence (eds.), Recoding Nature. Sydney, NSW: University of New South Wales Press, pp. 138-149.

Harmsworth, G. 2004. The role of Biodiversity in Maori Advancement: A Research Framework. He Pukenga Kōrero: A Journal of Māori Studies, 8 (1): 9-16. 
Harry, D. \& Kaneche, L. M. 2006. Asserting Tribal Sovereignty over Cultural Property: moving towards protection of genetic material and indigenous knowledge. Seattle Journal for Social Justice, 5 (1): 27-66.

Harvey, D. 2005. A Brief History of Neoliberalism. Great Britain: Oxford University Press.

Hazardous Substances and New Organisms Act [HSNO] Act 1996. Wellington, N.Z., Government Printer.

Hēnare, M. 2014. The Economy of Mana. In: D. Cook, C. H., P. Baskett, \& R. Irwin (eds.), Beyond the Free Market: Rebuilding a Just Society in New Zealand. Auckland, N.Z.: Dunmore, pp. 65-69.

Hēnare, M., Lythberg, B., Nicholson, A., \& C. Woods, 2017. Te Ohu Umanga Māori: temporality and intent in the Māori entrepreneurial team. In: C. Ben-Hafaïedh \& T. M. Cooney (eds.), Research Handbook on Entrepreneurial Teams: Theory and Practice. Cheltenham, Gloucestershire: Edward Elgar Publishing.

Hennick, M., Hunter, I., \& A. Bailey 2011. Qualitative Research Methods, London: SAGE.

Hernandez, A. 2013. I Never Really Had Any Role Models. In: D. M. Mertens, F. Cram, and B. Chilisa (eds.), Indigenous Pathways into Social Research. Walnut Creek, California: Left Coast Press, pp. 59-70.

Hindmarsh, R. \& G. Lawrence. 2004. Recoding nature: Deciphering the script. In: Lawrence, R. H. G. (ed.), Recoding Nature. Sydney, NSW: University of New South Wales Press, pp. 23-40.

Hudson, M. L., Ahuriri-Driscoll, A. L. M., Lea, M. G. \& Lea, R. A. 2007. Whakapapa - A Foundation for Genetic Research? Journal of Bioethical Inquiry, 4 (1): 43-49.

Hudson, M., Beaton. A., Milne, M., Port, W., Russell, K., Smith, B., Toki, V., Uerata, L., \& P. Wilcox. 2016b. Te Mata Ira - Guidelines for Genomic 
Research with Māori. [Online]. [Accessed 10 April 2018]. Available: https://www.waikato.ac.nz/_data/assets/pdf_file/0018/321534/TeMata-Ira-Genome-Research-Guidelines.pdf.

Hudson, M., Russell, K., Uerata, L., Milne, M., Wilcox, P., Port, R. V., Smith, B., Toki, V. \& Beaton, A. 2016a. Te Mata Ira-Faces of the Gene: Developing a cultural foundation for biobanking and genomic research involving Māori. AlterNative: An International Journal of Indigenous Peoples, 12 (4): 341-355.

Human Genome Project [HGP]. 2003. International Consortium Completes Human Genome Project: All Goals Achieved; New Vision for Genome Research Unveiled. [Online]. [Accessed 10 May 2018]. Available: https://www.genome.gov/11006929/2003-release-internationalconsortium-completes-hgp/.

Hutchings, J. 2002. Te whakaruruhau, te ukaipo: mana wahine and genetic modification. Thesis (PhD.) Victoria University of Wellington.

Hutchings, J. 2004a. Traditions and test tubes: Māori and GM. In: R. Hindmarsh \& G. Lawrence (eds.), Recoding Nature. Sydney, NSW: University of New South Wales Press, pp. 179-191.

Hutchings, J. 2004b. Claiming our ethical space - a mana wahine conceptual framework for discussing genetic modification. He Pukenga Kōrero: a journal of Māori Studies, 8 (1): 17-25.

Hutchings, J. 2007. Is Biotechnology an Appropriate Development Path for Māori? In: Ratuva, S. and A. T. P. Mead (eds.), Pacific Genes\& Life Patents: Pacific Indigenous Experiences \& Analysis of the Commodification \& Ownership of Life. In: A. T P. Mead \& S. Ratuva Wellington, N.Z.: Call of the Earth Llamado do la Tierra and The United Nations University Institute of Advanced Studies, pp. 23-33.

Hutchings, J. 2011. Kei Tua o Te Pae Hui Proceedings. [Online]. Accessed 4 Nov 2017. Available from: 
https://www.google.co.nz/url?sa=t\&rct=j\&q=\&esrc=s\&source=web\&cd $=2 \&$ cad $=$ rja\&uact=8\&ved=0ahUKEwj1qc6MtqPXAhVMv5QKHeAeCecQF ggtMAE\&url=http\%3A\%2F\%2Fwww.nzcer.org.nz\%2Fsystem\%2Ffiles\%2F Hui_Procedings_v3_Web_1_2.pdf\&usg=AOvVaw0NMduaZKkdjCkf1oY BkOl1.

Hutchings, J. 2015. Te Mahi Māra Hua Parakore: A Māori Food Sovereignty Handbook, Ōtaki, N.Z., Te Wānanga o Raukawa.

Hutchings, J. 2016. Bringing Māori food politics to the table: Decolonising food knowledge. In: J. Hutchings and J. Lee-Morgan (eds.), Decolonisation in Aotearoa: Education, research and practice. Wellington, N.Z.: NZCER Press, pp. 172-181.

Hutchings, J., \& P. Reynolds. 2004. The Obfuscation of Tikanga Maori in the GM Debate. [Online]. [Accessed 18 April 2018]. Available: http://www.rangahau.co.nz/assets/hutching_renolds/GE_hutchings_re ynolds.pdf.

Hutchings, J., Smith, J., Roskruge, N., Severne, C., Mika, J., \& J. Panoho,. 2017. Enhancing Māori Agribusiness Through Kaitiakitanga Tools. [Online]. [Accessed 29 April 2018]. Available: http://www.ourlandandwater.nz/assets/Uploads/VM-Think-PieceEnhancing-Maori-Agribusiness-July-2017.pdf.

Hutchings, J., Tipene, P., Carney, G., Greensill, A., Skelton, P., \& B. Mahinarangi. 2012. Hua Parakore: an indigenous food sovereignty initiative and hallmark of excellence for food and product production. MAI Journal, 1 (2): 131-145.

Iriwin, K. 1994. Māori Methods and Processes: An Exploration. Pacific Health Dialog. 7:13-17.

Jackson, M. 2007. Globalising and the Colonising State of Mind. In: M. Bargh (ed.) Resistance: An Indigenous Response to Neoliberalism. Wellington, N.Z.: Huia, pp. 167-182. 
Jackson, M. 2016. Decolonising Education. In: J. Hutchings and J. Lee-Morgan (ed.) Decolonisation in Aotearoa: Education, research and practice. Wellington, N.Z.: NZCER Press, pp. 39-47.

Jones, A. 2012. Dangerous Liaisons: Pākehā, kaupapa Māori and educational research. New Zealand Journal of Educational Studies. 47 (2): 100-112.

Joseph, R. 2012. Unsettling Treaty Settlements: Contemporary Māori Identity and Representation Challenges. In: Nicola R. Wheen, J. H. (eds.), Treaty of Waitangi Settlements. Wellington, N.Z.: Bridget Williams Books, pp. 151-165.

Kawharu, M. 2002. 'Outstanding Native Interest'. In: M. Kawharu (ed.), Whenua: Managing Our Resources. Auckland, N.Z.: Reed, pp. 145-166.

Kevin, M. E. \& N. J. Gemmell. 2017. Conservation demands safe gene drive. PLOS Biology, 15 (11): 1-8.

King Hunt, A. 2019 (forthcoming). Māori religious perceptions of novelty biotechnologies for introduced social wasp control: A Q Method study. Thesis (M.A.). Victoria University of Wellington.

Kingi, T. 2013. "Cultural bastions, farm optimisation and tribal agriculture in Aotearoa (New Zealand)", Conference Proceedings of the 22nd International Grassland Congress. Sydney, Australia.

Kinnear, S. 2004. Moving from GM organisms to organic farming. In: R. Hindmarsh \& G. Lawrence (eds.), Recoding Nature. Sydney, NSW: University of New South Wales Press, pp. 108-121.

Kumar, B. R. 2019. Wealth Creation in the World's Largest Mergers and Acquisitions Integrated Case Studies. Switzerland: Cham-Springer International Publishing.

Landcare Research Manaaki Whenua. 2019. Argentine Ant. [Image]. [Accessed 14 Feb 2019]. Available from: argentineants.landcareresearch.co.nz/identification.asp. 
Landcare Research Manaaki Whenua. n.d.-a. Bronze Beetle. [Image]. [Accessed 14 Feb 2019]. Available from: https://www.landcareresearch.co.nz/resources/identification/animals/ bug-id/what-is-this-bug/bugs-with-legs/6-legs/beetles/bronze-beetle.

Landcare Research Manaaki Whenua. n.d.-b. Light Brown Apple Moth. [Image]. [Accessed 14 Feb 2019]. Available from: https://www.landcareresearch.co.nz/resources/identification/animals/ bug-id/what-is-this-bug/bugs-with-legs/6-legs/moths-andbutterflies/light-brown-apple-moth,-leafroller-caterpillar.

Landcare Research Manaaki Whenua. n.d.-c. Mealybug Ladybird. [Image]. [Accessed 14 Feb 2019]. Available from: https://www.landcareresearch.co.nz/resources/identification/animals/ bug-id/what-is-this-bug/bugs-with-legs/6-legs/beetles/mealybugladybird.

Landcare Research Manaaki Whenua. n.d.-d. Leafroller Caterpillar. [Image]. [Accessed 14 Feb 2019]. Available from: https://www.landcareresearch.co.nz/resources/identification/animals/ bug-id/alphabetic-list-of-bugs/leafroller-caterpillar.

Landcare Research Manaaki Whenua. n.d.-e. Galleria mellonella (male). [Image]. [Accessed 14 Feb 2019]. Available from: https://www.landcareresearch.co.nz/resources/identification/animals/l arge-moths/image-gallery/pyraloid-moths/pyralidae.

Lee, J. 2009. Decolonising Māori narratives: Pūrākau as a method. MAl review, 2(3).

Lentin, A. 2018. Open Letter to Monash Bioethics Review. [Online]. [Accessed 4 Dec 2018]. Available: https://mediadiversified.org/2018/12/03/openletter-eugenics-is-back-in-vogue-again-from-the-observer-to-themonash-bioethics-review/.

Lester, P. 2018. The Vulgar Wasp, Wellington, N.Z.: Victoria University Press. 
Lester, P. J., Beggs. J., Brown, B. L., Gorenteman, R., Toft, R. J., Twindl, A., and D. Ward. 2013. The outlook for control of New Zealand's most abundant, widespread and damaging invertebrate pests: Social wasps. New Zealand Science Review, 70 (4): 56-62.

Lincoln, Y. S. 2002. Emerging Criteria for Quality in Qualitative and Interpretive Research. In: K. N. Denzin and Y. S. Lincoln. (eds.), The Qualitative Inquiry Reader. Thousand Oaks, California: SAGE, pp. 327-345.

Maaka, R., \& A. Fleras 2005. The Politics of Indigeneity. Dunedin, N.Z.: University of Otago.

Maclntyre, P., \& J. Hellstrom. 2015. An evaluation of the costs of pest wasps (Vespula species) in New Zealand. [Accessed 28 Nov 2017]. Available: http://www.doc.govt.nz/Documents/conservation/threats-andimpacts/animal-pests/evaluation-pest-wasps-nz.pdf.

Maeda, H. 2015. Response option configuration of online administered Likert scales. International Journal of Social Research Methodology, 18 (1): 1526.

Mahuika, R. 2008. Kaupapa Māori theory is critical and anti-colonial. MAl Journal, 3.

Mānuka Symposium. 2018. Hosted by the UMF Association \& Buddle and Finlay. 12 June 2018.

Marsden, R. M. 2003. The Woven Universe. Masterton, N.Z.: The Estate of Rev. Māori Marsden.

McCaslin, W. D., \& D. C. Breton 2008. Justice as Healing: Going Outside the Colonizers' Cage. In: K. N. Denzin, S. Y. Lincoln, \& L. T. Smith (eds.), Handbook of Critical and Indigenous Methodologies. Thousand Oaks: Sage, pp. 511-530.

McDonough, W. \& M. Braungart. 2002. Cradle to cradle. New York City: North Point Press. 
McFarlane, R. \& Roberts, M. 2005. Genetically Modified Organisms in New Zealand and Cultural Issues. In: H. P. S. Makkar, \& G. J. Viljoen (eds.), Applications of Gene-Based Technologies for Improving Animal Production and Health in Developing Countries. Dordrecht: Springer Netherlands, pp. 551-561.

Mead, A. 1998. Sacred Balance. He Pukenga Kōrero: A Journal of Māori Studies, $3(2): 22-27$.

Mead, H. M. 2003. Tikanga Māori: Living by Māori Values, Wellington, N.Z.: Huia.

Medin, D. L. \& M. Bang 2014. Who's Asking? : Native Science, Western Science, and Science Education. Cambridge, USA: MIT Press.

Mercier, O. R. 2013. Putting Māori history, society, and culture on the map. In: J. Moss and J. Cederwall (eds.), The Commons. Aotearoa: Free Range Press. pp. 28-31.

Mercier, O. R., Hunt, A., \& P. J. Lester. 2019 (forthcoming). Novel biotechnologies for eradicating wasps: seeking Māori studies students' perspectives with $Q$ method. Kotuitui: New Zealand Journal of Social Sciences.

Mercier, O. R., Hunt, A., \& Palmer, S. 2018. 'Controlling Pest Wasps in Aotearoa New Zealand with Biotechnologies? Māori Views.' Paper presented to World Indigenous Research and Education Conference August 2018, Guovdageaidnu, Norway.

Miller, T., \& L. Bell. 2012. Consenting to what? Issues of access, gate-keeping and 'informed' consent. In: T. Miller, M. Birch, M. Mauthner and J. Jessop (eds.), Ethics in Qualitative Research. London, U.K.: Sage. pp. 61-75.

Ministry for the Environment [MFE]. 2002. Public Discussion Paper: Improving the operation of the HSNO Act for new organisms. [Online]. [Accessed 7 May 2018]. Available from: 
http://www.mfe.govt.nz/sites/default/files/full-discussion-papersep02.pdf.

Ministry for the Environment [MFE]. 2004. Genetic modification - The New Zealand approach. [Online]. [Accessed 14 May 2018]. Available from: http://www.mfe.govt.nz/sites/default/files/genetic-modification-nzapproach.pdf.

Ministry for the Environment [MFE]. 2017. Resource Legislation Amendments 2017 - Fact Sheet 2. [Online]. [Accessed 19 Nov 2018]. Available from: https://www.mfe.govt.nz/sites/default/files/media/Fact\%20Sheet\%202 \%20-\%20Revised\%20functions\%20for\%20RMA\%20decision\%20makersamended.pdf.

Ministry of Business Innovation and Employment. 2007. Vision Mātauranga: Unlocking the Innovation Potential of Māori Knowledge, Resources and People. [Online]. [Accessed 21 Feb 2019]. Available from: https://www.mbie.govt.nz/assets/9916d28d7b/vision-mataurangabooklet.pdf.

Ministry of Business Innovation and Employment. 2017a. Māori economy investor guide. [Online]. [Accessed 15 April 2018]. Available from: http://www.mbie.govt.nz/info-services/infrastructure-growth/maorieconomic-development/documents-image-library/maori-economyinvestor-guide.pdf.

Ministry of Business Innovation and Employment. 2017b. The Advanced Genomics Research Platform. [Online]. [Accessed 26 April 2018]. Available from: http://www.mbie.govt.nz/info-services/scienceinnovation/investment-funding/how-we-invest/strategic-scienceinvestment-fund/advanced-genomics-research-platform.

Moorefield, J. C. n.d.. Te Aka Online Māori Dictionary. [Online]. [Accessed 22 Feb 2019]. Available from: https://maoridictionary.co.nz. 
Morgan, K. 2007. Waiora and Cultural Identity: Water Quality Assessment using the Mauri Model. AlterNative: An International Journal of Indigenous Peoples, 3 (1): 42-67.

Muru-Lanning, M. 2016. Tupuna Awa, Auckland, N.Z., Auckland University Press.

Mutu, M. 2002. Barriers to Tangata Whenua Participation in Resource Management. In: Kawharu, M. (ed.) Whenua: Managing Our Resources. Auckland, N.Z.: Reed, pp. 75-95.

Mutu, M. 2010. Ngāti Kahu Kaitiakitanga. In: Rachael Shelby, P. M. and M. Mulholland. (ed.) Māori and the Environment: Kaitiaki. Wellington, N.Z.: Huia, pp. 13-36.

Mutu, M. 2012. The sea I never gave. In: Nicola R. Wheen, J. H. (eds.), Treaty of Waitangi Settlements. Wellington, N.Z.: Bridget Williams Books. pp. 114123.

Mutu, M. 2018. Behind the smoke and mirrors of the Treaty of Waitangi claims settlement process in New Zealand: no prospect for justice and reconciliation for Māori without constitutional transformation. Journal of Global Ethics, 14 (2): 208-221.

Nana, G., Masrur, K., \& H. Schulze. 2015. Te Ōhanga Māori (The Māori Economy Report) 2013. [Online]. [Accessed 29 Nov 2017] Available from: http://www.tpk.govt.nz/en/a-matou-mohiotanga/business-andeconomics/maori-economy-report-2013.

Nana, G., Stokes, F., \& W. Molano. 2011. The Asset Base, Income, Expenditure and GDP of the 2010 Māori Economy. [Online]. [Accessed 3 April 2018]. Available from: http://www.berl.co.nz/assets/EconomicInsights/Economic-Development/Maori-Economy/BERL-2011-TheAsset-Base-Income-Expenditure-and-GDP-of-the-2010-MoriEconomy.pdf. 
New Zealand Government. 2016. New Zealand to be Predator Free by 2050 [Online]. [Accessed 14 Jan 2019]. Available: https://www.beehive.govt.nz/release/new-zealand-be-predator-free2050.

New Zealand Government. 2018. The Treasury Approach to the Living Standards Framework. [Online]. [Accessed 20 Feb 2019]. Available: https://treasury.govt.nz/sites/default/files/2018-02/tp-approach-toIsf.pdf.

New Zealand Wine. n.d.. Buckwheat and beneficial insects at Te Whare Ra. [Accessed 12 April 2018]. Available from: https://www.nzwine.com/en/winery/te-whare-ra-twr-/buckwheat-andbeneficial-insects-at-te-whare-ra

Owen, J. R. \& Kemp, D. 2013. Social licence and mining: A critical perspective. Resources Policy, 38 (1): 29-35.

Oye, K. A., Esvelt, K., Appelton, E., Catteruccia, F., Church, G., Kuiken, T., Lightfoot, S. B. Y., Mcnamara, J., Smidler, A., \& J. P. Collins 2014. Biotechnology. Regulating gene drives. Science, 345 (6197): 626-628.

Pauli, G. 2016. The Blue Economy Principles. [Online]. [Accessed 18 May 2018]. Available: https://www.theblueeconomy.org/principles.html.

Pihama, L. 2016. Positioning ourselves within kaupapa Māori research. In: J. Hutchings and J. Lee-Morgan (eds.), Decolonisation in Aotearoa: Education, research and practice. Wellington, N.Z.: NZCER Press, pp. 101113.

Plant and Food Research New Zealand. 2013. Apple leaf curlling midge. [Image]. [Accessed 14 Feb 2019]. Available from: https://www.plantandfood.co.nz/growingfutures/casestudies/delivering-clean-fruit-for-export/apple-leafcurling-midge.

Poata-Smith, E. 2004. Ka tika a muri, ka tika a mua?: Māori Protest Politics and the Treaty of Waitangi Settlement Process. In: P. Spoonley, C. 
Macpherson. \& D. Pearson. (eds.) Tangata Tangata: The Changing Ethnic Contours of New Zealand. Victoria, Australia: Thomson-Dunmore, pp. 5988.

Popay, A. 2008. Woolly apple aphid. [Image]. [Accessed 14 Feb 2019]. Available from: https://teara.govt.nz/en/photograph/17984/woolly-apple-aphid. Predator Free 2050 Ltd. 2018. Annual Report [Online]. [Accessed 14 Jan 2019]. Available from: https://pf2050.co.nz/app/uploads/2018/11/PF2050Limited-Annual-Report-2017-2018.pdf.

Predator Free 2050 Ltd. 2018. Annual Report. [Online]. [Accessed 14 Jan 2019]. Available: https://pf2050.co.nz/app/uploads/2018/11/PF2050-LimitedAnnual-Report-2017-2018.pdf.

Radio New Zealand. 2009. Bioethics Council to be disbanded. Available from: https://www.radionz.co.nz/news/national/12639/bioethics-council-tobe-disbanded [Accessed 3 May 2018].

Ratuva, S. 2007. Na Kilaka a vaka-Viti ni veikabula: Indigenous Knowledge and the Fijian Cosmos. In: A. T P. Mead \& S. Ratuva (eds.), Pacific Genes \& Life Patents: Pacific Indigenous Experiences \& Analysis of the Commodification \& Ownership of Life. Wellington, N.Z.: Call of the Earth Llamado do la Tierra and The United Nations University Institute of Advanced Studies, pp. 90-101.

Roberts, M. \& Fairweather, J. R. 2004. South Island Maori perceptions of biotechnology. Lincoln, N.Z.: Agribusiness and Economics Research Unit, Lincoln University.

Roberts, M., B. Haami, R. Benton, T, Satterfield, M. Finucane, M. Henare, and M. Henare. 2004. Whakapapa as a Māori Mental Construct: Some Implications for the Debate over Genetic Modification of Organisms. The Contemporary Pacific, 16 (1): 1-28. 
Rogers-Hayden, T. E. E. and J. R. Campbell. 2003. Re-negotiating Science in Environmentalists' Submissions to New Zealand's Royal Commission on Genetic Modification. Environmental Values, 12 (4): 515-534.

Roy, E. A. 2018. Australia and New Zealand at loggerheads over manuka honey trademark. [Online]. [Accessed 20 May 2018]. Available from: https://www.theguardian.com/world/2018/jan/12/australia-and-newzealand-at-loggerheads-over-manuka-honey-trademark.

Royal Commission on Genetic Modification (RCGM) 2001. Report of the Royal Commission on Genetic Modification, Chairman: Thomas Elchelbaum. Wellington, N.Z., New Zealand Government Printer.

Royal Society of New Zealand Act, 1997. Wellington, N.Z.: Government Printer.

Royal Society Te Apārangi. 2018a. The use of gene editing in the primary industries (discussion paper). [Online]. [Accessed 17 Oct 2018]. Available from: https://royalsociety.org.nz/assets/Uploads/The-use-of-geneediting-in-primary-industries-discussion-paper-DIGITAL.pdf.

Royal Society Te Apārangi. 2018b. Gene editing in the primary industries (technical paper). [Online]. [Accessed 17 Oct 2018]. Available from: https://royalsociety.org.nz/assets/Uploads/Gene-editing-in-primaryindustries-technical-paper.pdf.

Ruckstuhl, K., Thompson-Fawcett, M. \& Rae, H. 2014. Māori and mining: Indigenous perspectives on reconceptualising and contextualising the social licence to operate. Impact Assessment and Project Appraisal, 32 (4): 304-314.

Ruru, I. 2014. The Mauri Compass: a concept paper showing mauri compass as an evaluation tool in a RMA Freshwater context. Gisborne, N.Z.: Te Rūnanga o Turanganui a Kiwa.

Satterfield, T. \& M. Roberts. 2008. Incommensurate risks and the regulator's dilemma: considering culture in the governance of genetically modified organisms. New Genetics and Society, 27 (3): 201-216. 
Satterfield, T., Roberts, M., Henare, M., Finucane, M., Benton, R., \& M. Hēnare. 2005. Culture, Risk, and the Prospect of Genetically Modified Organisms as Viewed by Tāngata Whenua. [Online]. [Accessed 13 Sep 2018]. Available from: http://www.decisionresearch.org/wpcontent/uploads/2015/11/558.pdf.

Schmid, J. 2008. Phylloxera nymphs feeding on the roots. [Image]. [Accessed 14 $\begin{array}{llll}\text { Feb 2019]. } & \text { Available }\end{array}$ https://en.wikipedia.org/wiki/Phylloxera\#/media/File:Wurzellaeuse.jpg.

Scion. 2017. Scion's Te Papa Tipu Māori Plan. [Accessed 15 May 2017]. Available from: https://www.scionresearch.com/_data/assets/pdf_file/0018/51651/Sc ion_Maori_Plan.pdf.

Seafood New Zealand. n.d.. King Salmon. [Image]. [Accessed 14 Feb 2019]. Available from: https://www.seafood.co.nz/species/s/Species/show/king-salmon/.

Seini, M. 2004. Commodification and access: biotechnology and Australia's indigenous flora. In: R. Hindmarsh \& G. Lawrence (eds.), Recoding Nature. Sydney, NSW: University of New South Wales Press, pp. 192-205.

Shiva, V. \& W. Berry. 2014. The Vandana Shiva Reader. [Electronic Book]. [Accessed 16 April 2018]. Available from: http://www.jstor.org/stable/j.ctt12880j6.

Shiva, V. 2008. Soil Not Oil. London: Zed Books.

Shulze, H., \& S. Green. 2017. Tokona Te Taki Māori Futures Collective - Change Agenda: Income Equality for Māori. [Online]. [Accessed 16 April 2018]. Available from: https://uploadsssl.webflow.com/5a81d9daa7e787000152855e/5abad0fc60e600315cd0 c7ac_Tokona\%20te\%20Raki\%20\%20Income\%20Equity\%20for\%20Maori.pdf. 
Skyes, A. 2007. Blunting the System: The Personal Is the Political. In: Bargh, M. (ed.) Resistance: An Indigenous Response to Neoliberalism. Wellington, N.Z.: Huia, pp. 125-129.

Smith, C. 2006. Na Takoto Ana a Papatūānuku: the state of biotechnologies and Māori. In: Mulholland, M. (eds.), State of the Māori Nation: twenty-firstcentury issues in Aotearoa. Auckland, N.Z.: Reed, pp. 199-209.

Smith, C. 2007. Cultures of Collecting. In: M. Bargh (ed.) Resistance: An Indigenous Response to Neoliberalism. Wellington, N.Z: Huia, pp. 65-74.

Smith, C. 2014. Becoming a Kaupapa Māori Researcher. In: D. M. Mertens, F. Cram, and B. Chilisa, (eds.), Indigenous Pathways into Social Research: Voices of a New Generation. Walnut Creek, California: Left Coast Press, pp. 89-100.

Smith, G. 1990. "Research Issues Related to Māori Education", paper presented to NZARE Special Interest Conference, Massey University, reprinted in 1992. The Issues of Research and Māori, Research Unit for Māori Education, University of Auckland.

Smith, J. M. 2003. Hard to swallow: the dangers of GE food - an international exposé, Nelson, N.Z.: Craig Potton Publishing.

Smith, L. T. 2007. Pacific Genes\& Life Patents: Pacific Indigenous Experiences \& Analysis of the Commodification \& Ownership of Life In: A. T P. Mead \& S. Ratuva (eds.), Pacific Genes\& Life Patents: Pacific Indigenous Experiences \& Analysis of the Commodification \& Ownership of Life Wellington, N.Z.: Call of the Earth Llamado do la Tierra and The United Nations University Institute of Advanced Studies, pp. 74-81.

Smith, L. T. 2008. On Tricky Ground: Researching the Native in the Age of Uncertainty. In: K. N. Denzin \&, S. Y. Lincoln (eds.) The Landscape of Qualitative Research. Thousand Oaks, California: Sage, pp. 113-144.

Smith, L. T. 2012. Decolonizing Methodologies, Dunedin, N.Z.: Otago University Press. $2^{\text {nd }} e d n$. 
Smith, L. T. 2015. Choosing the Margins: The Role of Research in Indigenous Struggles for Social Justice. In: N. K. Denzin \&, M. D. Giardina (eds.), Qualitative Inquiry--Past, Present, and Future: A Critical Reader. Walnut Creek, California: Routledge, pp. 349-371.

Solomon, M. 2007. A Long Wait for Justice. In: M. Bargh (ed.) Resistance: An Indigenous Response to Neoliberalism. Wellington, N.Z.: Huia, pp. 75-84.

Sorrenson, M. P. K. 2014. Ko te Whenua te Utu / Land is the Price, Auckland, N.Z.: Auckland University Press.

Sowman, N. 2017. Short Term Discomfort for Long Term Gain: From Conventional to Conversion through to Organics: A Case Study. [Online]. [Accessed 10 April 2018]. Available from: https://www.kellogg.org.nz/uploads/media/Sowman_Nigel_Short_Term_Pain_Discomfort_for_Long_Term_Gain.pdf.

Spiller, C., Pio, E., Erakovic, L. \& M. Henare. 2011. Wise Up: Creating Organizational Wisdom Through an Ethic of Kaitiakitanga. Journal of Business Ethics, 104 (2): 223-235.

Stephenson, J. 2002. The Management of a Māori-owned Resource. In: Kawharu, M. (ed.) Whenua: Managing Our Resources. Auckland, N.Z.: Reed, pp. 169-191.

Sun, G. \& Riggs, A. D. 2017. A Simple and Cost-Effective Approach for In Vitro Production of Sliced siRNAs as Potent Triggers for RNAi. Molecular Therapy - Nucleic Acids, 8: 345-355.

Te Aho, L. 2008. Contemporary Issues in Māori Law and Society - The Tangled Web of Treaty Settlements Emissions Trading, Central North Island Forests and the Waikato River. Waikato Law Review, 16 (1): 229-250.

Te Kooti Whenua Māori (Māori Land Court). 2010. Māori Land Trusts: Te Ture Whenua Māori Act 1993. [Online]. [Accessed 24 July 2017]. Available from: 
https://www.maorilandcourt.govt.nz/assets/Documents/Publications/

MLC-maori-land-trusts-english.pdf.

Te Momo, O. H. F. 2007. Biotechnology: the language of multiple views. Biotechnology Journal, 2: 1179-1183.

Te Punga Somerville, A. 2011. “Neither Qualitative nor Quantitative: Kaupapa Māori Methodology, and the Humanities", paper presented at the Kei Tua o Te Pae Conference, Wellington, N.Z.

Te Rūnanga o Ngāi Tahu. 2017. Annual Report 2017. [Online]. [Accessed 22 May 2018]. Available from: http://ngaitahu.iwi.nz/wpcontent/uploads/2017/11/Manawa-Ngai-Tahu-Financial-Summary2017-Final-Lowres_1.pdf.

Te Tiriti o Waitangi, 1840. Wellington, N.Z.: Government Printer.

Teaiwa, T. K. 1995. Scholarship from a Lazy Native. In: E. Greenwood, K. Nemann and A. Sartori (eds.) Work in Flux. Parkville, Victoria: University of Melbourne.

Thomas, C. D., Moller, H., and G. M. Plunkett. 1990. The prevalence of introduced Vespula vulgaris wasps in a New Zealand beech forest community. New Zealand Journal of Ecology, 13: 63-72.

Victoria University of Wellington. 2018. Researches propose alternative to 'unachievable' Predator Free 2050. [News Item]. [Accessed 25 July 2018]. Available from: https://www.victoria.ac.nz/news/2018/07/researcherspropose-alternative-to-unachievable-predator-free-2050.

Waitangi Tribunal. 2011. Ko Aotearoa Tēnei, Taumata Tuatahi. [Online]. [Accessed 10 May 2018]. Available: https://forms.justice.govt.nz/search/Documents/WT/wt_DOC_6835605 4/KoAotearoaTeneiTT1W.pdf.

Wheen, N. R. \& J. Hayward. 2012. The Meaning of Treaty Settlements and the Evolution of the Treaty Settlement Process. In: N. R. Wheen \& J. Hayward 
(eds.), Treaty of Waitangi Settlements. Wellington, N.Z.: Bridget Williams Books, pp. 13-25.

Wiki Commons. n.d.. Codling moth. [Image]. [Accessed 14 Feb 2019]. Available from:

https://commons.wikimedia.org/wiki/Cydia_pomonella\#/media/File:Cy dia.pomonella.7162.jpg. 


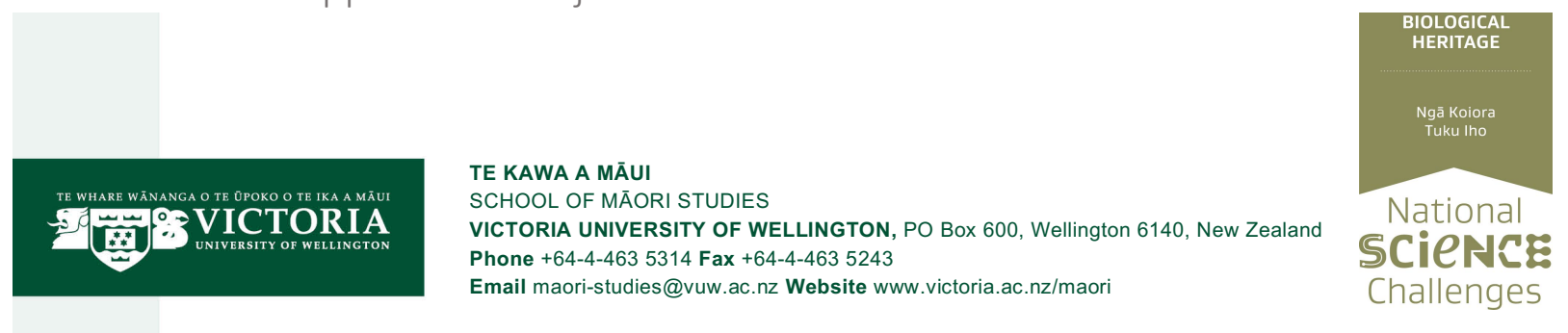

\section{Participant Information Sheet}

Project Title: Māori business perceptions of biotechnologies in pest wasp management

Researcher: Symon Palmer (Te Kawa a Māui, Master's student)

Who are we? / Ko Wai Mātou?

My name is Symon Palmer and I am a Master's student at Te Kawa a Māui / School of Māori Studies. My supervisor Dr Ocean Mercier is a Senior Lecturer at Te Kawa a Māui. In collaboration with Prof. Phil Lester from the School of Biological Sciences, and with the support of the National Science Challenge: Our Biological Heritage theme, we seek to find out what people think of selected nextgeneration biotechnological controls of pest wasps in Aotearoa New Zealand.

\section{About the project}

As a Māori business in an industry that faces biohazards and pests, we would like to hear your thoughts on pest management. In particular, what challenges your business faces currently and what pest management methods would you consider in the future.

We are interested in the potential benefits to your business (e.g. productivity or reduction of pest management costs) if pests were managed differently. However, what is often overlooked in statistics are the benefits outside of economic factors. Therefore, we are also interested to hear about the values that underpin your business: for example, if there any social or cultural benefits or threats that might arise by the use of bio-controls and potential eradication of pests.

By taking part in this research, you will help to give us a more detailed and up-todate picture of how biotechnologies are viewed in your industry from a Māori standpoint. Your thoughts will also inform this developing conversation and potentially steer future conversations by researchers on pest management for a healthy economy and environment in Aotearoa New Zealand.

\section{What's involved?}

I will interview you or your group in person at your location of business or choice. The interview would take around an hour and a half of your time. We will give you a koha in acknowledgement of your time and thoughts.

The audio recording of your interview will be stored on a password protected drive at Victoria University of Wellington. It will only be heard by myself, my supervisor. If you wish, I can provide you with a transcript for approval or amendment. You can opt to use a pseudonym to protect your identity or business. The finished research will be published as part of a thesis study. The data and analysis generated may also be used in seminars and journal publications.

c/o Landcare Research New Zealand Limited | P.0. Box 69040 | Lincoln 7640 | New Zealand 
You do not require any prior knowledge of biotechnologies. We can provide you with an explanation of these. We are more interested in your views on pest management and the values placed on it. We greatly value any perspectives you would like to share.

\section{Participants' Rights}

The Victoria University of Wellington Human Ethics Committee has approved this research (HEC\#24885). Participation in this study is entirely voluntary. You will be free to withdraw from the study at any time up to 2 weeks after the completion of your interview. No one other than myself, Symon (interviewer) my supervisor, Dr. Ocean Mercier, and possibly a transcriber, will listen to the audio files, or see the complete transcripts. Any research notes collected during our discussion will be kept confidential. However, if you would like opinions or information to be attributed to you in seminars and publications, please indicate so on the consent form. If you tick the option on the consent form we will email you publications produced from the research.

\section{Further Information}

If you have any queries relating to this project, please feel free to contact myself or my supervisor.

\section{Symon Palmer (Ngāi Te Rangi), Te Kawa a Māui \\ Email: symon.palmer@vuw.ac.nz \\ Phone: +64-4-463-5243 \\ Dr Ocean Ripeka Mercier (Ngāti Porou), Te Kawa a Māui \\ Email: Ocean.Mercier@vuw.ac.nz_Phone: +64-4-463-7457}

If you have any questions or concerns about the ethical conduct of this project, please contact:

Dr Judith Loveridge, Convener, Human Ethics Committee:

Email: Judith.Loveridge@vuw.ac.nz Phone: +64-4-463-6028 


\section{Māori business perceptions of biotechnologies in pest wasp} management

\section{CONSENT FORM - INTERVIEW}

I have been given sufficient explanation of this research. My questions about this project have been answered to my satisfaction. I understand that I may withdraw myself - and any information and recordings I have provided - from this study without having to give reasons or justification, but that I should do this no later than 2 weeks following the interview on (insert date).

I understand that any information that I provide will be kept confidential to the researchers, research assistant and transcriber; and that published results will not use my name; nor will opinions be attributed to me in research seminars or publications, unless I wish for them to be attributed. I am aware that I will be given an electronic copy of my interview that I can request an electronic transcript and that I can delete or change any of the comments I have made. I will endeavour to do this within 2 weeks of receiving my transcript. I understand that electronic data will be kept until the end of 2025 .

I agree to take part in this research (Please tick if you agree)

I consent to my interview being recorded to an audio device

I wish to be e-mailed a copy of my interview transcript

I would like for the information/opinions I give to be attributable to me by name or

I would like for the information/opinions I give to be attributable to me by a pseudonym [you can choose a pseudonym]

I would like to receive notifications of seminars and copies of publications arising from this research

Participant's signature: Date:

Participant's name:

Email address (for sending publications): 


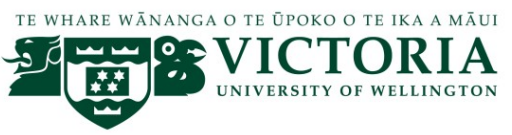

\section{Transcribing Confidentiality Agreement}

Project Title: Māori Business Perceptions of Biotechnologies in Pest Wasp Management

Principal

Investigator: Symon Palmer

$\mathrm{I}$, , agree to ensure that the audiotapes

I transcribe will remain confidential to _Ocean Mercier, Phil Lester and myself.

I agree to take the following precautions:

1. I will ensure that no person outside of the above-mentioned hears the recording.

2. I will ensure that no other person has access to my computer/device.

3. I will delete the files from my computer/device once the transcription has been completed.

4. I will not discuss any aspect of the recording with anyone except the above-mentioned.

Signature:

Date: 


\section{Primer: Five 'bio-controls' for control or eradication of introduced wasps \\ Te Kawa a Māui, Victoria University of Wellington}

As part of a Master's by thesis project: "Māori business perceptions of biotechnologies in pest wasp management".

\section{Summary of Biotechnologies}

1. RNA interference (RNAi [or Gene silencing/ gene editing]) - interruption of "messenger DNA" leading to non-expression of biological characteristics (such as fertility);

2. Gene drive - a trait or characteristic, like infertility, is driven through an entire population;

3. Trojan female - insert a genetically modified queen into a nest to produce infertile males;

4. Trojan mite - wasp-dwelling mites carry and spread pathogen into a nest; and

5. Pheromones - in trap lures, and for behavioural manipulation. 
Ranking of Pests that are of concern or disturbance to your business

\begin{tabular}{|c|c|c|c|c|c|c|c|}
\hline \multicolumn{2}{|c|}{ Disagree (least concerning) } & & & & & \multicolumn{2}{|c|}{ Agree (most concerning) } \\
\hline-4 & -3 & -2 & -1 & 0 & & \\
\hline & & & & & & & \\
& & & & & & & \\
\end{tabular}

Options given to participants:

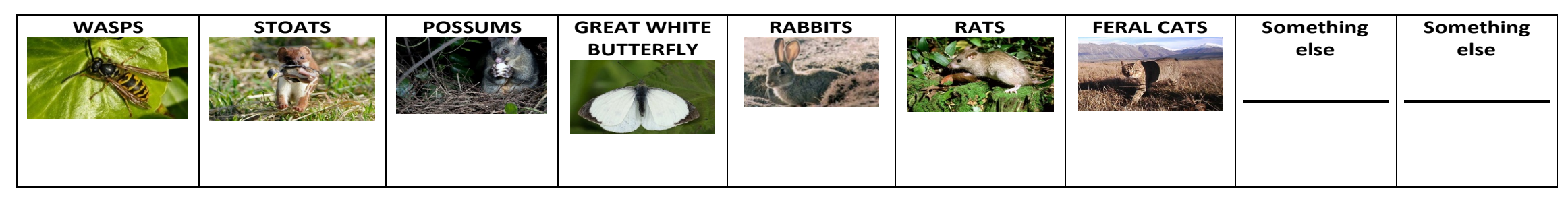


Ranking of Pests Management Tools in Aotearoa

\begin{tabular}{|c|c|c|c|c|c|c|c|c|}
\hline \multicolumn{2}{|c|}{ Disagree (least acceptable) } & \multirow[b]{2}{*}{-2} & \multirow[b]{2}{*}{-1} & \multirow[b]{2}{*}{0} & \multirow[b]{2}{*}{1} & \multirow[b]{2}{*}{2} & \multicolumn{2}{|c|}{ Agree (potential to adopt) } \\
\hline-4 & -3 & & & & & & 3 & 4 \\
\hline & & & & & & & & \\
\hline & & & & & & & & \\
\hline & & & & & & & & \\
\hline & & & & & & & & \\
\hline
\end{tabular}

Options given to participants:

\begin{tabular}{|c|c|c|c|c|c|c|c|c|}
\hline $\begin{array}{c}\text { Trojan female } \\
\text { modifying DNA } \\
\text { of a wasp } \\
\text { queen so she } \\
\text { produces } \\
\text { infertile males }\end{array}$ & $\begin{array}{l}\text { Trojan mite } \\
\text { introducing a } \\
\text { disease- } \\
\text { carrying mite } \\
\text { into a wasp } \\
\text { nest }\end{array}$ & $\begin{array}{l}\text { Pheromone } \\
\text { a pheromone } \\
\text { lure that } \\
\text { attracts wasps } \\
\text { into a trap }\end{array}$ & $\begin{array}{c}\text { RNA } \\
\text { interference } \\
\text { stopping the } \\
\text { expression of } \\
\text { traits by } \\
\text { interrupting } \\
\text { 'messenger' } \\
\text { DNA }\end{array}$ & $\begin{array}{l}\text { Gene drive } \\
\text { driving a } \\
\text { particular } \\
\text { genetic trait, } \\
\text { such as } \\
\text { infertility, into } \\
\text { a population's } \\
\text { offspring }\end{array}$ & $\begin{array}{l}\text { Non-species } \\
\text { specific poison }\end{array}$ & $\begin{array}{l}\text { Species- } \\
\text { specific } \\
\text { poison, such } \\
\text { as Vespex }\end{array}$ & $\begin{array}{c}\text { Manual } \\
\text { extraction of } \\
\text { nests }\end{array}$ & Do nothing \\
\hline
\end{tabular}




\begin{tabular}{|c|c|c|c|c|c|c|c|c|c|c|c|c|}
\hline LRE1 & Mātātā & Kererū & Mohua & Tữ̄ & Weka & Kārearea & $\begin{array}{l}\text { Kākāpō + } \\
\text { Toutouwai }\end{array}$ & Kākā & Pūkeko & Average & Median & Std Dev \\
\hline$\overline{\text { WASP }}$ & -1 & 3 & 1 & 1 & 0 & -3 & 3 & 2 & 3 & 1.00 & 1 & 2.06 \\
\hline STOATS & -4 & -3 & 4 & -2 & -2 & 1 & 0 & 0 & 4 & -0.22 & 0 & 2.86 \\
\hline POSSUMS & -3 & 2 & -2 & -4 & 1 & 3 & -2 & -1 & 1 & -0.56 & -1 & 2.40 \\
\hline RATS & -2 & 1 & 3 & 2 & -1 & -2 & 1 & -2 & 2 & 0.22 & 1 & 1.99 \\
\hline CATS & 0 & -4 & 2 & -1 & -4 & 2 & -1 & -4 & 0 & -1.11 & -1 & 2.42 \\
\hline RABBITS & 1 & -2 & -3 & -3 & -3 & 4 & -3 & 1 & -4 & -1.33 & -3 & 2.69 \\
\hline GREAT WHT & 2 & 0 & -1 & 3 & 2 & -2 & -4 & -3 & -3 & -0.67 & -1 & 2.55 \\
\hline OTHER A & 3 & 4 & 0 & 4 & 3 & -4 & 2 & 3 & -1 & 1.56 & 3 & 2.70 \\
\hline OTHER B & 4 & -1 & -4 & 0 & 4 & 0 & 4 & 4 & -2 & 1.00 & 0 & 3.08 \\
\hline
\end{tabular}

\begin{tabular}{|c|c|c|c|c|c|c|c|c|c|c|c|c|}
\hline LRE2 & Mātātā & Kererū & Mohua & Tūî & Weka & Kārearea & $\begin{array}{l}\text { Kākāpō + } \\
\text { Toutouwai }\end{array}$ & Kākā & Pūkeko & Average & Median & Std Dev \\
\hline Do nothing & -4 & -4 & 0 & 0 & -2 & -4 & -2 & -4 & -4 & -2.67 & -4 & 1.73 \\
\hline Manual extraction & -3 & -3 & 1 & 1 & -4 & 4 & -4 & 1 & -2 & -1.00 & -2 & 2.83 \\
\hline Non-species specific poi & 3 & 1 & 4 & 4 & -3 & -3 & 2 & -3 & -3 & 0.22 & 1 & 3.19 \\
\hline Species-specific poison & -2 & 4 & 3 & 3 & 2 & 3 & 3 & 2 & 4 & 2.44 & 3 & 1.81 \\
\hline Trojan-mite & 1 & 3 & -4 & -4 & 0 & 1 & -3 & -1 & 0 & -0.78 & 0 & 2.44 \\
\hline RNAi & -1 & -2 & -3 & -2 & 3 & -1 & 0 & 4 & -1 & -0.33 & -1 & 2.35 \\
\hline Gene drive & 2 & 0 & -1 & -1 & 4 & 0 & 1 & 3 & 2 & 1.11 & 1 & 1.76 \\
\hline Trojan female & 0 & -1 & -2 & -3 & -1 & -3 & 4 & -2 & 1 & -0.78 & -1 & 2.22 \\
\hline Pheromone lure & 4 & 2 & 2 & 2 & 1 & 2 & -1 & 0 & 3 & 1.67 & 2 & 1.50 \\
\hline
\end{tabular}


INTERVIEW PĀTAI

DATE TIME LOCATION

INTERVIEWEE CONSENT YES/NO

\section{PART ONE - INTRO AND BACKGROUND}

1. Mihi/Intro if appropriate

2. Go over Ethics, Consent Sheet, hand out copy of Primer for reference. Recap 5 techs.

3. Karakia - ask if it's okay or feels right to do a karakia

4. Re-introduce the purpose of this study and my positionality

5. Give background on the research topic e.g. NSC, Predator Free 2050, Wasps as a vehicle for the conversation on biotech, the five biotech's to be discussed.

6. Press Record.

\section{PART TWO - WARM UP QUESTIONS}

1) Looking over the Primer, are there any technologies that caught your eye? Did you want me to expand on any of the info?

2) Ranking exercise \#1 on types of pests. Speak to results.

3) Ranking exercise \#2 on types of pest management. Speak to results.

4) Discuss any pest issues in the business.

Examples

What are the current pests that your business has to deal with?

What are the current methods used to combat these pests?

How effective are they?

What are the costs associated with them (time, money, value)

What about wasps specifically, are they a problem at all?"

Are you actively seeking alternative pest management strategies, if so what kinds?

5) Are there any that you perceive to not be a pest? If so why? 


\section{PART THREE - VALUES part one}

This next section is about what values underpin your business.

1) How does being Māori inform your business practices and values?

2) What values are associated with your product and the customer?

3) Are there any other values your business takes on?

4) Of these values, how do they influence your position on general pest management?

And what about specifically to wasps?

\section{PART FOUR - BIOTECHNOLOGIES}

1) Thinking about the five novel biotechnologies presented to you in the primer (RNAi, Trojan Female, Trojan Mite, Gene Drive, Pheromones), would any of these be considered acceptable to your business in future pest management?

Why?

2) What would genetic modification of any sort mean to your business and the product you produce?

Would the product's value change? (brand, image, price)

3) In your opinion, what are the differences between genetic modification of food and the potential control of pests using biotechnologies?

4) Can you think of any businesses, even from other sectors that would benefit from biotechnologies in pest management?

5) Would biotechnologies affect your business and its Māori identity? (How?)

6) Are there any Māori values or tikanga you think might be affected by the use of biotechnologies in pest management? What about Genetic modification in food? (prompt answer with the negative or positive) 


\section{SCENARIO QUESTION}

7) Hypothetically speaking, how comfortable would you be if the government decided to implement one of these technologies, for example, gene drive, in wasps in 2025 . Would there be any ramifications to your business or the industry?

8) What about for another pest, say stoats or rats?

9) How would you like to see this discussion move forward? What needs to happen next?

\section{EXPLORING VALUES/NON-MARKET ACTIVITY}

1) Are there any forms of productivity in your business that are not money related?

2) Does your business partake in any not-for-profit activities?

3) What are some environmental considerations in your business and how do you enact them? (climate change, sustainable methods, operational equipment)

4) Thinking about what values your business has, and any non-market activities it might partake in... Are any of these linked to current pest management strategies?

5) Would biotechnologies have any impact on your businesses nonmonetary values?

6) Is there a way that these values might be enhanced in future pest management strategies?

END

NOTES 
